\author{
UNIVERSIDADE DE SÃO PAULO \\ INSTITUTO DE ESTUDOS BRASILEIROS \\ PROGRAMA DE PÓS-GRADUAÇÃO EM \\ CULTURAS E IDENTIDADES BRASILEIRAS
}

GUILHERME SOUZA CARVALHO DA ROCHA FREITAS

\title{
OLIVEIRA LIMA E A DIVULGAÇÃO DO BRASIL NO EXTERIOR (1908-1912): \\ ENTRE A HISTORIOGRAFIA, A CRÍTICA LITERÁRIA E A POLÍTICA EXTERNA BRASILEIRA
}

Versão Corrigida

SÃO PAULO 


\author{
UNIVERSIDADE DE SÃO PAULO \\ INSTITUTO DE ESTUDOS BRASILEIROS \\ PROGRAMA DE PÓS-GRADUAÇÃO EM \\ CULTURAS E IDENTIDADES BRASILEIRAS
}

\title{
OLIVEIRA LIMA E A DIVULGAÇÃO DO BRASIL NO EXTERIOR (1908-1912): \\ ENTRE A HISTORIOGRAFIA, A CRÍTICA LITERÁRIA E A POLÍTICA EXTERNA BRASILEIRA
}

GUILHERME SOUZA CARVALHO DA ROCHA FREITAS

Dissertação apresentada ao Programa de Pós-Graduação em Culturas e Identidades Brasileiras do Instituto de Estudos Brasileiros da Universidade de São Paulo, para a obtenção do título de Mestre em Filosofia, Área de Concentração: Estudos Brasileiros

Orientador: Prof. Dr. Paulo Teixeira Iumatti

\section{Versão Corrigida}

São Paulo 
Freitas, Guilherme Souza Carvalho da Rocha

Oliveira Lima e a divulgação do Brasil no exterior (1908-1912) : entre a historiografia, a crítica literária e a política externa brasileira / Guilherme Souza Carvalho da Rocha Freitas -- São Paulo, 2017.

Orientador : Prof. Dr. Paulo Teixeira lumatti.

Dissertação (Mestrado) - Universidade de São Paulo. Instituto de Estudos Brasileiros. Programa de Pós-Graduação em Culturas e Identidades Brasileiras. Area de concentração: Estudos Brasileiros. Linha de pesquisa: Brasil: a realidade da criação, a criação da realidade.

Versão do título para o inglês: Oliveira Lima and the dissemination of Brazil abroad (1908-1912) : between historiography, literary criticism and Brazilian foreign policy.

Descritores: 1. Oliveira Lima, Manuel, 1867-1928 2. Historiografia 3. História do Brasil 4. Crítica Literária 5. Política Externa I. Universidade de São Paulo. Instituto de Estudos Brasileiros. Programa de PósGraduação II. Título. 


\section{FOLHA DE APROVAÇÃO}

Guilherme Souza Carvalho da Rocha Freitas

Oliveira Lima e a divulgação do Brasil no exterior (1908-1912): entre a historiografia, a crítica literária e a política externa brasileira.

Dissertação apresentado ao Programa de Pós-Graduação em Culturas e Identidades Brasileiras do Instituto de

Estudos Brasileiros da Universidade de São Paulo, para a obtenção do título de Mestre em Filosofia, Área de Concentração Estudos Brasileiros

Aprovado em:

Banca Examinadora

Prof. Dr.

Instituição: Assinatura:

Prof. Dr.

Instituição: Assinatura:

Prof. Dr.

Instituição: Assinatura: 
Aos espíritos de Manuel, José Maria e Joaquim, que tanto me iluminaram nesta jornada. 


\section{Agradecimentos}

Agradeço primeiramente ao meu orientador Paulo Teixeira Iumatti. Seu constante incentivo e decididos conselhos foram fundamentais para que eu seguisse caminho e enfrentasse a tarefa da reflexão e escrita. Agradeço principalmente por sempre acreditar que um internacionalista, como eu, poderia ter sucesso nessa empreitada pelos "ofícios do historiador".

Não poderia deixar de agradecer o convite do Professor Paulo para fazer parte do núcleo de pesquisa "O Brasil no Mundo: ontem e hoje". Nossas leituras e debates têm me trazido reflexões no sentido de pensar a inserção do Brasil no Mundo a partir de novos paradigmas e certamente é um incentivo para prosseguir nos estudos das relações internacionais.

Agradeço aos professores do IEB com que mantive diálogo mais próximo, principalmente Alexandre de Freitas Barbosa, Ana Paula Cavalcanti Simione, Jaime Tadeu Oliva, Marcos Antônio de Moraes. Nosso convívio em seus cursos foram parte importante nesse meu processo de formação intelectual e suas idéias certamente influenciaram a forma como venho pensando o Brasil.

Agradeço também aos professores e funcionários do IEB com que tive a honra de compor a Comissão de Apoio Administrativo-Financeiro. Ali tive a oportunidade de compreender de maneira mais ampla o funcionamento do Instituto e da Universidade e a seriedade com que as questões são ali tratadas me dão a esperança de que o IEB vai continuar avançando em seu importante trabalho. Agradeço também a Rosely, Cristina e Daniele, funcionárias da Divisão Acadêmica, pela atenção e presteza que dedicam aos alunos doeste programa de pós-graduação.

À professora Sara Albieri agradeço o acolhimento que me dedicou em suas disciplinas no curso de História da FFLCH-USP. Como seu aluno e estagiário pude me aprofundar em reflexões historiográficas e espero apresentar aqui um trabalho à altura de seus ensinamentos. Ao professor Ricardo Souza de Carvalho agradeço a ajuda dedicada no aprofundamento das questões da literatura e da historiografia e sobretudo nos importantes conselhos e direcionamentos na ocasião de minha banca de qualificação. Devo ressaltar ainda a paixão 
compartilhada que temos pelo Oliveira Lima e os diálogos que mantivemos no sentido de entender este nosso Homem de Letras. Agradeço também à professora Suhayla Kalil da FESPSP pelos esforços em clarear os meandros da política internacional e dialogar em nossas reflexões sobre a política externa brasileira.

Ao Embaixador José Viegas Filho agradeço a oportunidade de ter compartilhado comigo sua experiência diplomática e suas idéias sobre a política externa brasileira. Seu curso sobre o Brasil no Mundo e nossas conversas em almoços e cafés somente me trouxeram mais certezas sobre o importante papel reservado ao Itamaraty na inserção internacional do Brasil.

Agradeço a CAPES, de quem recebi uma bolsa durante um período deste mestrado. Seu auxílio material certamente foi decisivo para o sucesso deste trabalho.

Agradeço com afeto a meus pais, cujo apoio incondicional em termos espirituais, emocionais e materiais foram fundamentais para que eu superasse as dificuldade cotidianas de um intelectual em formação. Com eles compartilho a alegria de nossas conquistas e espero, um dia, retribuir todo carinho que sempre me dedicaram.

Ao meu primo-irmão Rafael de Souza Carvalho Melhem e ao meu amigo-irmão Marcel Villemor Jofily de Lima agradeço a alegria de dividir comigo um lar durante toda esta empreitada. Nossa Monarquia de Maracangalha e nossa novíssima e desfalcada Republiqueta das Bananas ouviram conversas profundas e amenas, choros e bossas. Agradeço por saberem entender e respeitar meu silêncio da reflexão, minha agonia da escrita e minha epifania das idéias.

Por fim, não posso esquecer meus queridos confrades Renato Rodrigues Leite Nalini, Bruno Ferreira Martins, Iberê Moreno Rosario e Barros e Maurízio Oliveira Terenzio, da Confraria da Paulicéia Desvairada. Nossos momentos de descontração e reflexão boêmia e nossos projetos quase-modernistas-de-22 preenchem minha alma e me dão força para seguir nesta jornada. 
"Ai esta terra ainda vai cumprir seu ideal, ainda vai tornar-se um imenso Portugal" Fado Tropical, Chico Buarque de Hollanda 


\section{Resumo}

FREITAS, Guilherme Rocha. Oliveira Lima e a divulgação do Brasil no exterior (1908-1912): entre a historiografia, a crítica literária e a política externa brasileira. 2017. Dissertação (Mestrado em Culturas e Identidades Brasileiras) - Instituto de Estudos Brasileiros da Universidade de São Paulo. São Paulo.

O tema de nosso estudo é a atividade de divulgação do Brasil no exterior empreendida pelo diplomata e historiador Manuel de Oliveira Lima. A atividade foi realizada de forma mais intensa entre os anos de 1908 e 1912, período correspondente àquele em que o diplomata ocupou o cargo de Ministro Plenipotenciário da Legação do Brasil em Bruxelas, Bélgica.

Tratava-se de conferências em Academias e Universidades e de artigos para revistas literárias, nas quais Oliveira Lima versava sobre a formação histórica da nacionalidade brasileira e tecia críticas literárias sobre escritores brasileiros, a fim de que se divulgassem tais assuntos no exterior - mais precisamente em algumas capitais europeias.

Procuramos ao longo do estudo entender o sentido desta atividade. Isto nos levou a articular nossa compreensão de que a divulgação se relacionava aos posicionamentos de Oliveira Lima diante das discussões intelectuais em torno da questão da nacionalidade brasileira e a uma política externa brasileira defendida e executada pelo diplomata diante das questões da inserção do Brasil no Mundo.

Palavras-Chave: Oliveira Lima, Manuel (1867-1928); História do Brasil; Historiografia; Crítica Literária; Política Externa 


\begin{abstract}
FREITAS, Guilherme Rocha. Oliveira Lima and the divulgation of Brazil abroad (1908-1912): between historiography, literary criticism and Brazilian foreign policy. 2017. Dissertation (Master's Degree in Brazilian Cultures and Identities) - Institute of Brazilian Studies, University of São Paulo. Sao Paulo.
\end{abstract}

The theme of our study is the Brazilian divulgation activity undertaken by the diplomat and historian Manuel de Oliveira Lima. The activity was most intensively carried out between 1908 and 1912, a period corresponding to that in which the diplomat held the position of Minister Plenipotentiary of the Legation of Brazil in Brussels, Belgium.

These were lectures in Academies and Universities and articles for literary magazines, in which Oliveira Lima dealt with the historical formation of Brazilian nationality and undertake literary critiques about Brazilian writers, in order to disseminate such subjects abroad - more precisely in some European capitals.

Throughout the study, we effort to understand the meaning of this activity. This led us to articulate our understanding that the disclosure was related to the positions of Oliveira Lima in the face of the intellectual discussions around the issue of Brazilian nationality and to a Brazilian foreign policy defended and executed by the diplomat regarding the issues of Brazil's insertion in the World.

Keywords: Oliveira Lima, Manuel (1867-1928); History of Brazil; Historiography; Literary Criticism; Foreign Policy 


\section{Sumário}

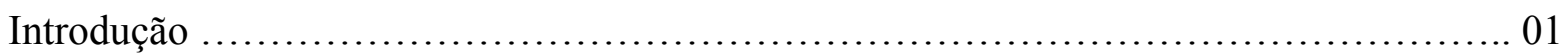

Capítulo 1 - Buscando Oliveira Lima em seu contexto intelectual ........................ 22

1.1 - Algumas idéias fundamentais do ambiente naturalista: Evolucionismo e Civilização.

1.2 - Reflexões sobre o contexto intelectual brasileiro do final do XIX e início do $\mathrm{XX}$.

Capítulo 2 - Rede de Sociabilidade Intelectual e posicionamentos de Oliveira Lima 45

2.1 - Rede, pautas e instituições ............................................... 46

2.1 .1 - IHGB .......................................................... 47

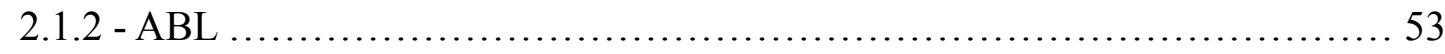

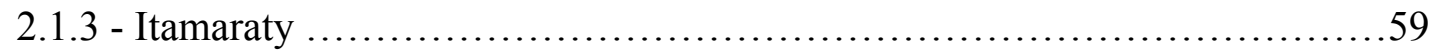

Capítulo 3 - A divulgação do Brasil no exterior (1908 - 1912) ........................... 73

3.1 - A atividade de divulgação ............................................. 75

3.1.1 - Conferências ........................................................ 75

3.1 .2 - Revиe ............................................................. 90

3.2 - O sentido da divulgação ................................................... 97

3.2.1 - O que se diz sobre o sentido da divulgação .......................... 97

3.2.2 - Entre o Homem de Letras e o Diplomata ................................. 99

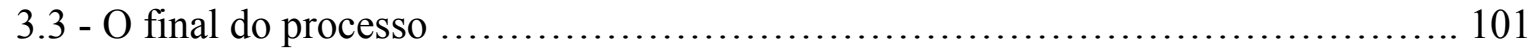

Conclusão ................................................................ 104

Referências Bibliográficas ................................................ 107

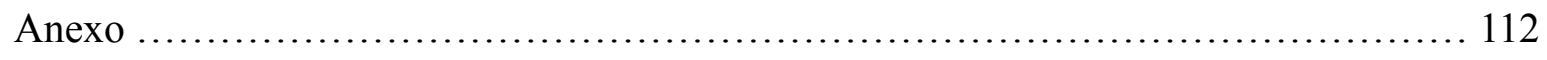

Sobre a evolução de uma cidade do Novo Mundo do XVI ao XX século ............ 112

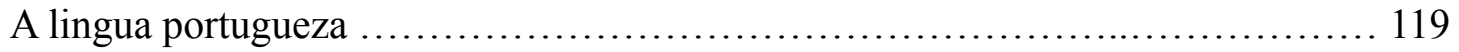




\section{Introdução}

"Embaixador Intelectual do Brasil". Assim foi apresentado o diplomata Manuel de Oliveira Lima aos membros do Instituto Nobel da Academia Sueca pelo Dr. Göran Björkman, durante sua visita à instituição em 1909. Àquela altura, Oliveira Lima vinha ganhando fama na Europa por conta de uma série de conferências que pronunciava sobre as "coisas da cultura e da história do Brasil", entendidas por nós como uma atividade de divulgação do Brasil no exterior empreendida pelo diplomata.

Este trabalho pretende estudar esta atividade, realizada de forma mais intensa entre os anos de 1908 e 1912, período correspondente àquele em que o diplomata ocupou o cargo de Ministro Plenipotenciário da Legação do Brasil em Bruxelas, acumulando à esta função a representação do Brasil em Estocolmo. ${ }^{1}$ Tratava-se, na realidade, de conferências em Academias e Universidades e de artigos para revistas literárias, nas quais Oliveira Lima versava sobre a formação histórica da nacionalidade brasileira e tecia críticas literárias sobre escritores brasileiros, a fim de que se divulgassem tais assuntos no exterior - mais precisamente em algumas capitais europeias.

No início da pesquisa, o estudo tinha a hipótese de que trava-se de divulgar para a Europa - e sobretudo para Paris, modelo de civilização e local onde Lima fez suas mais importantes conferências - aquilo que era culturalmente produzido no Brasil em termos dos mesmos padrões civilizacionais europeus, de modo posicionar o Brasil enquanto país civilizado nos trópicos, estando ele portanto no mesmo patamar das demais nações civilizadas europeias. Embora não seja o objetivo desta introdução versar de maneira aprofundado a respeito da temática dos artigos e conferências de Oliveira Lima em sua atividade de divulgação do Brasil no exterior, cabe aqui pontuar a visão do diplomata a respeito do país, sua cultura e sua formação histórica.

Pode-se dizer que Oliveira Lima via a cultura brasileira intrinsicamente ligada à tradição européia de maneira geral - e a partir de continuidade com a tradição portuguesa, de maneira específica - como se devido à sua formação histórica o país se configurasse em uma "Portugal americana", herdando portanto em sua nacionalidade aspectos da "tradição superior

\footnotetext{
${ }^{1}$ MALATIAN, Teresa. Oliveira Lima e a construção da nacionalidade. Bauru: EDUSC, 2001. p.227.
} 
da civilização ocidental", da "tradição da civilização latina" por vias lusitanas. ${ }^{2}$ A noção de “Civilização nos Trópicos” era, assim, a "idéia de Brasil” defendida por Oliveira Lima.

Vale aqui ressaltar que tal visão de mundo, tal "idéia de Brasil" tem como diálogo um ideário mais amplo da elite brasileira dos anos finais do século XIX e iniciais do século XX, sendo portanto compartilhada em certo grau por parcela da sociedade em que se insere o diplomata e historiador. ${ }^{3}$ Mais do que isto, esta visão de Oliveira Lima, mesmo que reelaborada, de certa maneira não difere muito daquela já defendida por Varnhagen. ${ }^{4}$ Daí vem a possibilidade de Oliveira Lima se valer de tal discurso para ganhar notoriedade e disputar “imagens de Brasil” perante seus pares.

Um outro ponto colocado no início da pesquisa buscava compreender se esta atividade se relacionava aos posicionamentos de Oliveira Lima diante das discussões intelectuais em torno da questão da nacionalidade brasileira ou a uma política externa brasileira defendida e executada pelo diplomata diante das questões da inserção do Brasil no Mundo. Com o decorrer dos estudos, passamos a entender que poderia se tratar de ambas as possibilidades, de maneira articulada. Assim, assumimos tal constatação como segunda hipótese do estudo.

O estudo busca verificar as possibilidades e os limites das hipóteses colocadas. Busca também explorar e aprofundar os mecanismo e articulação que dão sentido às hipóteses.

Para tal, o trabalho irá partir de uma abordagem multidisciplinar, pertinente, portanto, enquanto estudo desenvolvido no programa de pós-graduação multidisciplinar em Culturas e Identidades Brasileiras do Instituto de Estudos Brasileiros. Acredita-se que tal postura seja a melhor maneira de se compreender a complexidade e de se chegar a uma resposta satisfatória para a questão central proposta.

Deste modo, iremos nos valer de maneira relativamente livre de metodologias, temáticas de estudo e abordagens da História e das Relações Internacionais. Mais especificamente, iremos nos valer de sugestões metodológicas e temáticas de estudo da

\footnotetext{
2 PRADO, Antonio Arnoni. Dois Letrados e o Brasil Nação: A obra crítica de Oliveira Lima e Sérgio Buarque de Holanda. São Paulo: Editora 34, 2015. p.31-44.

${ }^{3}$ NEEDEL, Jeffrey D. Belle Époque tropical: Sociedade e Cultura de Elite no Rio de Janeiro na Virada do Século. $2^{\circ}$ edição. São Paulo: Companhia das Letras, 2003.

${ }^{4}$ VELLOZO, Júlio Cesar de Oliveira. Um Dom Quixote gordo no deserto do esquecimento. Oliveira Lima e a construção de uma narrativa de nacionalidade. 2012. 219 p. Dissertação (Mestrado em Culturas e Identidades Brasileiras) - Instituto de Estudos Brasileiros, Universidade de São Paulo, São Paulo.
} 
História Intelectual, História Cultural, História Política, História das Relações Internacionais e da Análise da Política Externa.

Uma das premissas deste trabalho é a de que a atividade de divulgação do Brasil no exterior foi praticada por Oliveira Lima enquanto intelectual. Nossa definição de intelectual vai, aqui neste trabalho, no mesmo sentido daquele empregado por Angela de Castro Gomes em seu estudo sobre os historiadores do início do século XX:

(...) a noção de intelectual, ela mesma de contornos fluidos, algo que se transforma
com o tempo, indicam dificuldades que se traduzem na impossibilidade de uma
definiçãao rígida. A opção, nesse caso, foi adotar uma concepção mais restrita de
intelectual, que privilegiasse a ideia de produtor de bens simbólicos envolvido direta
ou indiretamente na arena política. Esse "pequeno mundo", no dizer de Jean-Paul
Sartre, é composto por especialistas no processo de criação e transmissão cultural,
que despertam a atenção dos envolvidos com o "círculo de poder político" por suas
capacidades de interpretar a realidade social e produzir "visões de mundo".5

Na realidade - ainda do esteio de Gomes - talvez um termo mais adequado à época seja mesmo o de "Homens de Letras". De qualquer maneira, iremos nos valer ao longo deste trabalho dos dois termos, entendidos enquanto sinônimos.

A atividade de divulgação do Brasil no exterior foi executada por Oliveira Lima a partir de textos, de discursos, de atos de fala em que se trata intelectualmente da "idéia de Brasil". Cabe, assim, a investigação desta atividade enquanto caso pertinente ao estudo das idéias a partir da História Intelectual e da História das Idéias e ao estudo dos intelectuais a partir da História Política. Daí vem nossa opção metodológica por nos valer de propostas de Quentin Skinner e Jean-François Sirinelli.

Quanto a Skinner, o presente trabalho pretende se valer - de forma não rigorosa, vale ressaltar - de algumas sugestões metodológicas apresentadas em seu texto "Significação e compreensão na história das ideias". ${ }^{6}$ Este texto é considerado fundamental na constituição teórico-metodológica da "Escola de Cambridge" da História das Ideias. Nele, Skinner tece criticas a certas posturas metodológicas vigentes à época e propõe uma nova abordagens para os estudos da área.

Segundo Skinner, os dois preceitos - ou crenças, como coloca o autor - fundamentais a serem criticados são: (1) a crença de que a missão do historiador é estudar e interpretar textos

\footnotetext{
${ }^{5}$ GOMES, Angela de Castro. História e Historiadores. Rio de Janeiro: Editora FGV, 2013. p.38-39.

${ }^{6}$ SKINNER, Quentin. Significação e compreensão na história das ideais. In: Visões da Política: sobre os métodos históricos. Algés, Portugal: Difel, 2005.
} 
clássicos pelo fato de eles terem uma relevância perene ao apresentar sabedorias intemporais e ideias universais; (2) a crença de que a melhor maneira de interpretar os textos clássicos é se concentrar naquilo que ele diz sobre conceitos fundamentais e questões recorrentes.

A crítica de Skinner se baseia nas constatações de que é impossível estudar apenas o que o texto diz sobre conceitos fundamentais e questões recorrentes, uma vez que temos expectativas e preconceitos que determinam nossa compreensão a partir daquilo que nos é familiar, questão colocada como o "dilema da prioridade dos paradigmas".

Outra crítica vem no sentido de constatar que estas crenças não nos levar a entender o que o autor do texto clássico estava querendo dizer com sua enunciação. Estas crenças e dilemas levam, segundo Skinner, a absurdos históricos, que por sua vez resultam naquilo que chama de mitologias: a "Mitologia das Doutrinas", a "Mitologia da Coerência" e a "Metodologia da Prolepse".

Não cabe aqui a este trabalho aprofundar a análise a respeito de cada uma destas mitologias a fim de compreender a argumentação teórica empreendida por Skinner quando da proposição sua metodologia. O importante aqui é evidenciar a solução apresentada pelo autor a fim de que se superem estas mitologias, abrindo assim novas perspectivas ao estudo da História das Ideias.

Sugere Skinner que deve-se interpretar não apenas o significado de que foi dito por dado autor em seu texto, mas sobretudo a intenção que o autor pode ter tido ao dizer aquilo que disse. Ou seja, para se compreender um texto a questão fundamental é saber o que o autor, escrevendo em sua época e para um público específico, podia na prática ter procurado comunicar através de seu discurso.

Mas do que isto, para Skinner faz-se necessário para tal um predicamento essencialmente linguístico quando da análise do texto. A fim de compreender de fato as intenções do autor é preciso definir as relações entre dada expressão e seu contexto linguístico, de modo a decodificar as intenções do autor ao se valer de dada expressão. Assim, é importante estudo do contexto social enquanto quadro para análise dos significados que alguém poderia ter tentado comunicar.

Neste trabalho buscaremos, de alguma maneira, compreender quais eram as intenções de Oliveira Lima e a que público estava se dirigindo ao pronunciar seus discursos a respeito do Brasil em sua atividade de divulgação do país no exterior. Além disso, buscaremos 
compreender o contexto linguístico de seu tempo, de modo a captar o significado das expressões e conceitos de que se valia em seus textos. Com isto, esperamos ser possível captar a riqueza das tomadas de posição de Lima para as questões pertinentes à sua época.

De modo a complexificar o estudo da atividade de Oliveira Lima, vamos nos valer também de metodologia proposta por Sirinelli quando do estudo dos intelectuais como atores políticos, em voga a partir do ressurgimento dos estudos franceses sobre História Política. ${ }^{7}$ Dentre as diversas abordagens apresentadas por Sirinelli, parece interessante a este trabalho a proposta de compreender a atuação dos intelectuais a partir do estudo de suas redes de sociabilidade.

Para o autor, o meio intelectual se constituí como um "pequeno mundo estreito", onde os laços se atam em torno de estruturas produtoras de conhecimento, como por exemplo o conselho editorial de uma editora ou um instituto histórico. Estas estruturas são as denominadas "redes de sociabilidade intelectual".

Há nelas duas dimensões interessantes a serem observadas: são espaços de sociabilidade e disputas entre os intelectuais ao mesmo tempo em que apresentam como lugares de fermentação intelectual. Ou seja, as redes de sociabilidade intelectual podem ser observatórios das disputas por prestígio pessoal - e político - entre os intelectuais ao mesmo tempo em que podem ser observatórios da movimentações das idéias.

Assim, as relações entre os intelectuais dentro das redes assim como os debates em torno das idéias constituem-se nos dois fatores fundamentais a serem compreendidos quando do estudos das redes. Compreendemos, deste modo, que devemos nos ater à observação de dois fatores fundamentais: (1) a dinâmica da rede e o relacionamento e disputas pessoais entre os intelectuais que compões; (2) as pautas e questões intelectuais postas em debate.

Para tal, entendemos ser essencial compreender também o posicionamento pessoal dos intelectuais a serem observados, procurando entender o status de seu relacionamento com os demais intelectuais, sua posição ocupada dentro da estrutura da rede e seu posicionamento intelectual quanto às pautas em questão.

A partir de tal perspectiva, neste trabalho buscaremos compreender a atividade de Oliveira Lima dentro da lógica de sua rede de sociabilidade intelectual. Pretendemos verificar

\footnotetext{
${ }^{7}$ SIRINELLI, Jean-François. Os intelectuais. In: RÉMOND, René (Org.). Por uma história política. 2. ed. Rio de Janeiro: Editora FGV, 2003.
} 
se seus posicionamentos intelectuais - expressados em seus discursos - fazem sentido dentro da dinâmica e pautas das instituições e dos pares que compõe sua rede.

A partir das abordagens metodológicas de Skinner e Sirinelli esperamos ser possível buscar respostas para a hipótese da atividade estar vinculada a questões pessoais de Oliveira Lima enquanto intelectual.

Outra hipótese do presente trabalho é a de que a atividade de divulgação do Brasil no exterior foi praticada por Oliveira Lima enquanto diplomata, enquanto executor de política externa. Partiremos, assim, para uma digressão que encara o presente trabalho enquanto estudo de caso pertinente a abordagens teórico-metodológicas da História das Relações Internacionais e da Análise de Política Externa. Tal digressão será feita a partir da óptica da dimensão cultural das Relações Internacionais, uma vez que compreendemos que aí se oferecem as proposições mais relevantes e pertinentes ao presente trabalho.

A pergunta central, aplicada aqui neste trabalho ao caso de Oliveira Lima, é recurso metodológico de investigação de estudos a respeito das relações cultural nas Relações Internacionais:

\begin{abstract}
Nos anos de 1990, num esforço de formular uma teoria das relações internacionais, Jean-Baptiste Duroselle dedicou algumas páginas de um de seus últimos livros ${ }^{8}$ às relações culturais, as quais identificou num rol das relações pacíficas entre os Estados, ao lado das relações comerciais, financeiras e político-militares. Para Duroselle, as relações culturais são classificadas em dois tipos: espontâneas e de política cultural. As primeiras são estabelecidas entre indivíduos de uma maneira acidental. As outras fazem parte de uma política de Estado ou de uma ação de grupos privados, em maior ou menor medida seguindo a geopolítica do país de origem e com acordo/coordenação de seus respectivos ministérios das relações exteriores. ${ }^{9}$
\end{abstract}

Assim, inspirados por esta postura metodológica de Duroselle, entendemos que uma questão central a ser respondida pelas investigações sobre as relações cultural nas Relações Internacionais é justamente o questionamento sobre a natureza da atividade ou ação cultural no exterior: se trata de atividade estabelecida entre indivíduos ou faz parte de uma política de Estado ?

Ao adotarmos tal pergunta central neste estudo, não significa que concordemos inteiramente com a postura de Duroselle. Principalmente, não entendemos que a ação

\footnotetext{
${ }^{8}$ DUROSELLE, Jean-Baptiste. Tout empire périra: théorie des relations internationales. Paris: Armand Colin, 1992.

${ }^{9}$ SUPPO, Hugo Rogélio; LESSA, Mônica Leite. O estudo da dimensão cultural nas Relações Internacionais: contribuições teóricas e metodológicas. In: LESSA, Mônica Leite; GONÇALVES, Williams da Silva. História das Relações Internacionais: teoria e processos. Rio de Janeiro: Ed UERJ, 2007. p. 231.
} 
enquanto relação estabelecida entre indivíduos se trate de algo acidental. Sobretudo quando este indivíduos são intelectuais ${ }^{10}$, havendo aí interesses e disputas entre os indivíduos, mesmo que em um campo diverso das disputas entre os Estados. Apesar disto, entendemos se tratar de uma pergunta central interessante no sentido de ser um fio condutor das investigações.

A obra de Duroselle se processa dentro da chamada "escola francesa" dos estudos em História das Relações Internacionais, cujas delimitações dos objetivos de estudos e procedimentos metodológicas iniciais foram propostos pelo historiador francês Pierre Renouvin, sobretudo a partir de sua obra Histoire des relations internationales, datada de 1953. ${ }^{11}$ Tais objetivos de estudos e procedimentos metodológicos foram posteriormente sumarizados na obra de caráter teórico Introduction à l'histoire des relations internationales $^{12}$, escrita em 1964 conjuntamente por Renouvin e Duroselle.

Os estudos da "escola francesa" são paradigmáticos para o pensamento francês em Relações Internacionais ao tratar metodologicamente a área de estudos não como concepção teórica e modelar da Ciência Política, mas sim como interdisciplinar da Ciência Política com a História, cujos fundamentos teórico-metodológicos apresentam o conceito de "forças profundas". É no entendimento da cultura enquanto um elemento das "forças profunda" que Hugo Rogélio Suppo e Mônica Leite Lessa encaram a questão da dimensão cultural enquanto fator importante quando dos estudos das Relações Internacionais:

Afirmamos assim a visão de que a dimensão cultural é parte fundamental das relações internacionais. Embora não seja tratado como uma problemática especifica pelas análises da chamada escola realista, por exemplo, o tema cultural aparece aí como um elemento das "forças profundas", no sentido que lhe é atribuído por Pierre Renouvin. Dessa forma, a cultura é esta como algo que, em maior ou menor medida, norteia a política externa dos países e que, portanto, é instrumentalizada pelo Estado em busca de influência e prestígio no cenário internacional. ${ }^{13}$

\footnotetext{
${ }^{10}$ Vide que nos valemos neste estudo de abordagens propostas por Skinner e Sirinelli a fim de compreender as questões pertinentes aos intelectuais.

${ }^{11}$ SARAIVA, José Flávio Sombra. História das Relações Internacionais: o objeto de estudo e a evolução do conhecimento. In: SARAIVA, José Flávio Sombra (Org.). História das Relações Internacionais Contemporâneas: da sociedade internacional do século XIX à era da globalização. São Paulo: Ed. Saraiva, 2008. p. 10-16.
}

12 RENOUVIN, Pierre; DUROSELLE, Jean-Baptiste. Introdução à história das relações internacionais. São Paulo: DIFEL, 1967.

${ }^{13}$ SUPPO, Hugo Rogélio; LESSA, Mônica Leite. Op. Cit. In: LESSA, Mônica Leite; GONÇALVES, Williams da Silva. História das Relações Internacionais: teoria e processos. Rio de Janeiro: Ed. UERJ, 2007. p.224. 
Tal conceituação talvez se encontre, do ponto de vista historiográfico, na retomada da importância dos estudos em História Política após terem sido problematizados pela Escola dos Annales. ${ }^{14}$ Ao apresentar o conceito de "forças profundas" como central para a análise das Relações Internacionais, uma idéia que nos vem à mente é a de que os autores talvez queiram propor que o estudo da disciplina deve se ater ao estudo da "média e longa duração" de Fernand Braudel, a fim de que se compreendam com a devida complexidade da perspectiva histórica os fenômenos do Sistema Internacional.

Assim, a Escola Francesa, paradigma teórico-metodológico fundamental no estudo da dimensão cultural nas Relações Internacionais, entende a cultura enquanto fator pertencente às "forças profundas", fundamental, portanto, para a compreensão da formulação da política externa dos Estados e dos fenômenos do sistema internacional. Neste mesmo sentido vai a compreensão do historiador francês Jean F. Freymond sobre a cultura enquanto "força profunda", enquanto conceito pertencente à dimensão das "análises da conjuntura" braudelianas:

(...) enquanto sistema de referência coletiva, a cultura própria de cada Estado/ sociedade constitui um dos fundamentos da política externa dos Estados, com a qual ela contribui para influenciar o curso. Orienta da mesma maneira as relações transnacionais. Em todos os casos, ela modela em grande parte o ambiente no qual as políticas são elaboradas e executadas. Influi sobre a visão, a percepção e o comportamento dos atores, sejam governamentais ou não. Condiciona sua forma de analisar uma situação e determina em parte a maneira de encará-la. A cultura é uma força profunda no sentido entendido por Pierre Renouvin. Constitui também um dos elementos da conjuntura definida por Fernand Braudel. Todo sistema cultural é complexo e compreende vários componentes. Todos os aspectos de um sistema dado não influenciam identicamente as relações exterior de um Estado. Alguns pesam mais do que outros. Assim, provavelmente é o sistema de valores e do conjunto das normas que orientam as mentalidades coletivas e governa os comportamentos. ${ }^{15}$

Assim, compreender os "sistemas de valores" e o "conjunto de normas" de determinado contexto histórico torna-se tarefa fundamental na compreensão da formulação da policia externa dos Estados. Aplicando tais formulações ao contexto de Oliveira Lima - qual seja, o contexto no qual se insere a diplomacia do Brasil no início do século XX - o presente trabalho irá buscar compreender quais eram os "sistemas de valores" dos formuladores da política externa brasileira.

\footnotetext{
${ }^{14}$ MILZA, Pierre. Política interna e política externa. In: RÉMOND, René. Por uma História Política. $2^{\circ}$ edição. Rio de Janeiro: Editora FGV, 2003.

15 FREYMOND, Jean, F. Rencontres de cultures et relations internationales. Relations Internationales, $1980, \mathrm{n}$. 24. p.405.
} 
Ainda sobre a "escola francesa", merece destaque a introdução do conceito da dimensão cultural enquanto campo de estudos para as Relações Internacionais feita por Marcel Merle na conferência "O papel do fator cultural nas Relações Internacionais", realizada em 1980. Segundo o autor, além das dimensões política, econômica e tecnológica, as Relações Internacionais deveriam se preocupar também com a dimensão cultural, de modo a tornar as análises mais preparadas para lidar com a complexidade da realidade. Assim, o autor ao mesmo tempo que critica as visões demasiadamente estreitas dos paradigmas realista (política), liberal (econômica) e da interdependência (tecnológica), não as rejeita, propondo que mais uma dimensão, a cultural, seja considerada nas análises.

Mais ainda, para Merle o fator cultural é relevante politicamente por ser capaz de "... controlar e direcionar a distância o comportamento dos outros sem ter que ocupar militarmente o espaço. (...) O campo cultural, onde se forjam os sistemas de valores, é, portanto, um terreno conflitual, em que as relações de força são exercidas em permanência ${ }^{\prime 1}{ }^{16}$ Há aqui, talvez, uma visão que não exclui o paradigma realista, por exemplo, somando-se a este de modo a tornar a análise mais complexa.

O fator cultural nos estudos das relações internacionais não é abordado apenas na “escola francesa, aparecendo também, a partir de outras leituras, nas Teorias das Relações Internacionais. Cabe aqui, assim, uma revisão bibliográfica das diversas maneiras como a cultura é abordada pelo campo de estudos.

$\mathrm{Na}$ obra de Hans Morgenthau temos o conceito de "imperialismo cultural" enquanto abordagem da dimensão cultural nos estudos do paradigma realista. Outra abordagem interessante vem do paradigma marxista, mais especificamente nas análises de "sistema mundo" de Immanuel Wallerstein e, sobretudo, nas suas considerações a respeito daquilo que denominou de "Universalismo Europeu" enquanto retórica do poder. Vale ainda pontuar a maneira como o realista Edward Carr trabalha com o conceito de "poder político advindo da opinião" e como o instrumentalista liberal Joseph Nye trabalha com o conceito de "Soft Power" enquanto instrumento de política externa.

Em Morgenthau, o termo "imperialismo cultural" aparece como um uma forma de dominação de uma cultura por outra, semelhante à dominação militar e econômica, apesar de mais sutil e efetiva por permitir "o controle das mentes dos homens como ferramenta para a

\footnotetext{
${ }^{16}$ MERLE, Marcel. Forces et enjeux dans les relations internationales. Paris: Economica, 1985.
} 
modificação das relações de poder entre as nações ${ }^{17}{ }^{17}$ Assim, a cultura é vista sobretudo do ponto de vista político, como algo capaz de gerar e exercer poder. Vale aqui destacar que enquanto realista, Morgenthau considera para a compreensão do sistema internacional a centralidade da dimensão política. Assim, não é de se estranhar que mesmo considerando a cultura enquanto um fator, ele apareça enquanto ferramenta política, enquanto ferramenta de poder.

Já Immanuel Wallerstein se vale da questão da retórica, da dimensão dos valores difundidos e intrínsecos a certos discursos, para discutir a questão da imposição da civilização e do progresso, do processo de ocidentalização por parte dos países centrais aos países periféricos do "sistema-mundo", sobretudo em sua obra $O$ Universalismo Europeu. ${ }^{18} \mathrm{O}$ autor nos será valioso quando do estudo dos "sistemas de valores", da ambientação da cena intelectual na qual se inserem os formuladores e executores da política externa brasileira do início do século XX.

Já em Edward Carr, há o entendimento de três poderes políticos: o militar, o econômico e o da opinião. A dimensão cultural aparece de modo tangente no poder da opinião uma vez que este, através da propaganda, é capaz de trabalhar no ideário, na mentalidade dos indivíduos. Assim, existe um poder político baseado nas idéias, nas mentalidades. Perspectiva também interessante para, juntamente com as anteriormente apresentadas, compreender de que maneira se formou a opinião, o ideário e a mentalidade da elite cultural e política brasileira do período.

Por fim, vale ainda pontuar o conceito de "Soft Power" de Joseph Nye enquanto instrumento de política externa. ${ }^{19}$ Segundo o autor, este instrumento pode ser aplicado como forma de exercer poder de maneira mais branda a partir da cultura. Em outras palavras, a promoção cultural para o exterior pode ser um instrumento de política externa importante por transmitir ideias e valores e, assim, exercer poder. Deve-se, entretanto, haver certa cautela metodológica com a abordagem de Nye pelo fato de ela ter sido formulada com o objetivo de

\footnotetext{
17 MORGHENTHAU, Hans Joachim. A politica entre as nações: a luta pelo poder e pela paz. Brasília: Ed. Universidade de Brasília, 2003.

18 WALLERSTEIN, Immanuel. O universalismo europeu: a retórica do poder. São Paulo: Boitempo Editorial, 2007.
}

${ }^{19}$ NYE Jr, Joseph. Soft Power: the means to success in world politics. Nova York: Public Affairs, 2004. 
instrumentalizar a política externa norte-americana, num contexto portanto bastante diverso daquele das relações entre Brasil e Europa do início do século XX.

Apresentado o paradigma teórico-metodológico da dimensão cultural das Relações Internacionais a partir da abordagem da Escola Francesa e pontuados alguns conceitos da aplicação da dimensão cultural apreendidos nas Teorias da Relações Internacionais, acreditamos agora ser interessante também pontuar algumas proposições teóricometodológicas propostas pelo campo da Análise de Política Externa. Este esforço pode ser útil no sentido de pontuar conceitos e questões de relevância a servirem de base para o estudo a respeito das atividades de Oliveira Lima enquanto política externa brasileira que faça sentido aos objetivos propostos pela chancelaria Barão do Rio Branco à frente do Itamaraty entre 1902 e 1912.

Optou-se por basear o presente trabalho em torno de três obras fundamentais: "Diplomacy and domestic politics: the logic of two-level games" de Robert Putman, "Foreing Policy Analysis: classic and contemporany theory" de Valerie Hudson e "Ideas and Foreing Policy: Beliefs, Institutions, and Political Change" de Judith Goldstein e Robert Keohane. Nos parágrafos seguintes será realizada a revisão bibliográfica das obras, de modo a pontuar alguns conceitos e questões fundamentais.

A obra de Putman vai no sentido de estudar o papel da burocracia pública estatal no processo de tomada de decisão em política externa, de modo a "abrir a caixa-preta" do Estado. ${ }^{20}$ Vale ressaltar que o Estado é aqui considerado como um ator multifacetado, ou seja, há uma série de atores domésticos dentro do Estado - como políticos, ministérios, congresso e diversos grupos de interesse - não consistindo ele, portanto, num ator unidimensional. Ao realizar este movimento de abertura, Putman se vale de uma metodologia que pretende observar a dinâmica dos jogos de interesses dos diversos atores domésticos em atuação em dois diferentes "tabuleiros": a política interna e a política externa.

A partir desta metodologia, Putman constata que os interesses em um determinado "tabuleiro" podem influenciar no resultado do outro "tabuleiro", de modo que torna-se necessário contextualizar os cenários político interno e externo, além de identificar os interesses dos diversos atores domésticos nos diversos "tabuleiros". Trata-se da metodologia dos “jogos de dois níveis".

\footnotetext{
${ }^{20}$ PUTMAN, Robert. Diplomacy and domestic politics: the logic of two-level games. Massachusetts: MIT Press.
} International Organization, v.42 n3, Summer 1988. 
Ao aplicar a metodologia de Putman ao estudo das atividades de Oliveira Lima, constata-se que tal ação pode ter sido influenciada ou pode de algum modo influenciar as políticas internas do Brasil no contexto da Primeira República. Vale ainda ressaltar que além das possíveis questões já pontuados quanto às intencionalidades externas da política, cabe também verificar quais eram os interesses internos do Itamaraty, de Rio Branco e de Oliveira Lima perante as questões políticas internas.

Mais do que isso, podemos nos inspirar no conceito de "jogos de dois níveis" para entender de que maneira Oliveira Lima, enquanto indivíduo, jogava ao mesmo tempo em diversos "tabuleiros" distintos dentro das instituições de sua rede de sociabilidade intelectual: o Itamaraty, a ABL e o IHGB.

A obra de Hudson parte do mesmo pressuposto teórico de Putman quanto à necessidade de se "abrir a caixa-preta" do Estado, também pela autora considerado como ator multifacetado, composto portanto de diversos atores domésticos.

Parte fundamental da obra de Hudson é sua abordagem metodológica baseada no conceito de que existem diferentes níveis de análise a serem observados quando da Análise de Política Externa. ${ }^{21}$ A autora propõe assim quatro diferentes níveis de análise a serem observados: 1) Líder ou Nível Individual: aqui considera-se que determinada política pode ter sido formulada ou atende a interesses num nível individual, de um líder específico que pode ser o Chefe de Estado ou então o Líder de uma determinada burocracia; 2) Grupo: aqui considera-se um grupo de indivíduos como formuladores ou interessados em determinada política, sejam eles pertencentes a algum núcleo palaciano, burocracia ou grupo de interesse $^{22}$; 3) Burocracia: aqui se aprofunda a análise a respeito do funcionamento interno de determinada burocracia estatal, de modo a compreender seu processo de formulação de políticas e seus interesses perante outras burocracias ou sobre determinada pauta; 4) Cultura: aqui a autora leva em consideração aspectos culturais - tais como ideias, valores, visões sobre a identidade nacional - que permeiam os atores domésticos de determinado Estado em determinado contexto e que podem de alguma maneira influenciar na formulação de suas políticas.

\footnotetext{
${ }^{21}$ HUDSON, Valerie. Foreing Policy Analysis: classic and contemporany theory. USA: Rowman \& Littlefield Publishers, 2007.

${ }^{22}$ Note que os níveis podem se somar na análise, sendo que o fato de uma política ter sido formulada por um grupo não exclui necessariamente o papel do Líder deste grupo na formulação. A mesma lógica se aplica aos demais níveis de análise.
} 
Vale ainda notar que a autora chama a atenção para que se considerem durante a análise de determinada política questões como a posição ocupada pela agente doméstico a ser estudado em relação ao tomador de decisão da política, assim como sua relevância, representatividade e atitude ativa em relação a determinado assunto em pauta. Ou seja, a autora ressalta para o fato de que deve-se mapear o poder dos diferentes atores domésticos sobre a formulação e a condução de certa política, de modo a compará-los quanto à suas capacidades de atuação.

Ao aplicar as recomendação metodológicas de Hudson ao estudo da política externa da chancelaria Rio Branco, destaca-se de imediato a questão dos diferentes níveis de análise, sobretudo no que tange à posição ocupada pelo líder e chefe da burocracia: o Barão do Rio Branco e Oliveira Lima enquanto indivíduos perante o Itamaraty. Entretanto, deve-se estudar também se há relações do Chanceler com Oliveira Lima e Joaquim Nabuco enquanto "grupo" responsável pela política externa, assim como o estudo do Itamaraty, sua dinâmica e processos internos e sua posição perante os demais atores domésticos.

Interessante também é a aplicação do nível de análise cultural ao caso em questão ${ }^{23}$. Ao considerar a mentalidade, o conjunto de valores e a concepção de identidade nacional dos diversos atores domésticos envolvidos na formulação da política externa brasileira no contexto da Belle Époque, nota-se uma relação imediata com um imaginário de origem europeia - e sobretudo francesa - a partir de ideias como civilização e modernidade. Este paradigma metodológico retoma a série de discussões propostas por Wallerrstein a respeito de como se formou e de que forma atua esta mentalidade perante os atores domésticos brasileiros. Vale reafirmar que este mesmo conjunto de valores e idéias da Belle Époque como as já citadas civilização e modernidade - se apresentam explicitamente na imagem de um Brasil enquanto Nação civilizada, como se verá, divulgada por Oliveira Lima para a Europa, berço do ideário em questão.

Goldstein e Keohane também abordam em sua obra a questão das ideias enquanto fator relevante a ser considerado na Análise de Política Externa. Cabe aqui ressaltar sobretudo a abordagem teórica dos autores ao propor a compreensão das "Visões de Mundo" de determinado contexto somada à análises mais empíricas sobre políticas efetivamente

\footnotetext{
${ }^{23}$ Note as relações com as abordagens teórico-metodológico da dimensão cultural das Relações Internacionais, apresentadas anteriormente.
} 
implementadas, seus interesses, disputas e resultados. ${ }^{24}$ Deste modo é possível apreender com maior grau de complexidade os mecanismo de formulação de determinada política.

Os autores observam que determinada "Visão de Mundo" tem impacto de fato na formulação de uma política a partir do momento em que é selecionada e acordada enquanto "guia", ou seja, enquanto base conceitual comum dos formuladores da política. Neste momento esta "Visão de Mundo" adquire um papel de coordenação de parâmetros, estabelecendo limites e diretrizes de formulação. A partir deste fenômeno ideias se institucionalizam, tornam-se parte da "Visão de Mundo" do ator doméstico formulador da política.

Ao aplicar a metodologia proposta por Goldstein e Keohane ao estudo da atividade de Oliveira Lima enquanto política externa, abre-se a perspectiva de estudar e compreender de maneira mais complexa a institucionalização da "Visão de Mundo" Belle Époque no Itamaraty. Em outras palavras, a abordagem de Goldstein e Keohane permite que se estude ideias como "civilização" e "modernidade" enquanto pertencentes à "Visão de Mundo" do Ministério e seu corpo diplomático no período em questão, e não somente enquanto pertencente aos indivíduos da sociedade de um modo mais genérico.

Vale, por fim, ressaltar que o presente estudo compreende que a atividade de Oliveira Lima, numa perspectiva da dimensão cultural das Relações Internacionais, pode ser entendida enquanto uma "política cultural externa". Assim, iremos nos valer ao longo do trabalho da definição apresentada por Suppo e Lessa:

(...) parece-nos que o conceito operatório mais apropriado é o de política cultural externa, pois, com exceção de encontros pessoais e espontâneos, até certo ponto nenhuma relação ou ação cultural realiza-se sem a autorização, o acordo e o apoio (político e/ou econômico) do Estado, quando não é francamente planificada, dirigida e subvencionada pelo mesmo. O estudo das políticas culturais externas dos países é, a nosso ver, uma engenharia de pesquisa válida, na medida em que revela, à la fois, a importância das mesmas no conjunto das políticas externas dos países, os tipos de ações privilegiadas, os estágios e avanços (ou não) de tais políticas, as geopolíticas das ações, os atores envolvidos (intelectuais, artistas, diplomatas, etc.), os produtos oferecidos )literatura, rádio, cinema, etc.), os meios de ação (congregação religiosas, colégios, escolas de línguas, centros culturais, bolasse de estudo, etc.), os resultados obtidos, o impacto dessas políticas a longo prazo para os países concernidos e o sentido dos projetos desenvolvidos.

$(\ldots)$

${ }^{24}$ GOLDSTEIN, Judith; KEOHANE, Robert. Ideas and Foreing Policy: Beliefs, Institutions, and Political Change. Ithaca: Cornell University Press, 1993. 
No entanto, ainda resta a pergunta: o que é política cultural? Por política cultural externa compreendemos um conjunto de ações planejado para amparar e/ou fomentar os laços entre as nações. ${ }^{25}$

Como podemos notar, a definição de "política cultural externa" vai no sentido exato daquilo que elencos como uma das hipóteses do trabalho, qual seja a atividade de divulgação do Brasil no exterior enquanto conjunto de atividades planejada por Oliveira lima para amparar e/ou fomentar os laços entre o Brasil e a Europa.

Assim, feita a revisão bibliográfica de algumas obras que abordam a dimensão cultural das Relações Internacionais e de abordagens teórico-metodológicas em Análise de Política Externa acredita-se terem sido esclarecidas as questões teórico metodológicas deste trabalho.

Este trabalho se insere, naturalmente, dentro de uma série de estudos a respeito de Manuel de Oliveira Lima. A seguir serão pontuados alguns desses trabalhos de modo que possamos fazer um esforço de localizar o presente estudo perante os demais.

Evidente que essas obras trazem visões e enfoques diferentes, cada uma com seus méritos e limitações, mas que em conjunto apresentam uma base a partir da qual se pode trabalhar. São elas: o relato de Gilberto Freyre, Oliveira Lima, Don Quixote Gordo ${ }^{26}$; o texto de Barbosa Lima Sobrinho, Oliveira Lima, sua vida e sua obra contido na coletânea Oliveira Lima: Obra Seleta ${ }^{27}$, organizada por Sobrinho; a biografia em três volumes escrita por Fernando da Cruz Gouvêa, Oliveira Lima: uma biografia ${ }^{28}$; o livro advindo da tese de livredocência de Teresa Malatian, Oliveira Lima e a construção da nacionalidade ${ }^{29}$; os textos de Antonio Arnoni Prado, Ângela de Castro Gomes e Paulo Roberto de Almeida, contidos no volume 24 da Revista Remate de Males (IEL Unicamp, 2004), dedicado exclusivamente ao estudo de Oliveira Lima; o ensaio ${ }^{30}$ (2010) e o livro ${ }^{31}$ (2015) homônimos, Dois Letrados e o Brasil Nação de Antônio Arnoni Prado; o texto de Carlos Guilherme Mota, Oliveira Lima e

25 SUPPO, Hugo Rogélio; LESSA, Mônica Leite. Op. Cit. In: LESSA, Mônica Leite; GONÇALVES, Williams da Silva. História das Relações Internacionais: teoria e processos. Rio de Janeiro: Ed. UERJ, 2007. p.242-244.

${ }^{26}$ FREYRE, Gilberto. Oliveira Lima, Don Quixote Gordo. Recife: Universidade Federal de Pernambuco, 1968.

${ }^{27}$ SOBRINHO, Barbosa Lima. Oliveira Lima: Obra Seleta. Rio de Janeiro: Instituto Nacional do Livro, 1971.

${ }^{28}$ GOUVÊA, Fernando da Cruz. Oliveira Lima: uma Biografia. Recife: Instituto Arqueológico, Histórico e Geográfico de Pernambuco, 1973. 3 vols.

${ }^{29}$ MALATIAN, Teresa. Op. Cit., 2001.

${ }^{30}$ PRADO, Antônio Arnoni. Dois letrados e o Brasil nação: Sérgio Buarque de Holanda e Oliveira Lima (no prelo). Indefinido: Indefinido, 2010.

${ }^{31}$ PRADO, Antonio Arnoni. Op. Cit., 2015. 
nossa formação ${ }^{32}$; a dissertação de Maria Theresa Diniz Forster para o Curso de Altos Estudos do Instituto Rio Branco (IRB-MRE), Oliveira Lima e as relações exteriores do Brasil: o legado de um pioneiro e sua relevância atual para a diplomacia brasileira ${ }^{33}$; e a dissertação de Mestrado de Júlio de Oliveira Vellozo, Um Dom Quixote gordo no deserto do esquecimento. Oliveira Lima e a construção de uma narrativa de nacionalidade ${ }^{34}$.

Já Gilberto Freyre traz um relato pessoal e - quase que - carinhoso sobre Oliveira Lima, dando ênfase ao seu temperamento idealista e "autêntico" a fim de justificar os percalços da vida do biografado. Interessante pela proximidade entre Freyre e Lima, mas, justamente por isto, um tanto enviesado em defesa do amigo e, talvez até, com uma leitura romântica de sua trajetória.

Barbosa Lima Sobrinho, a partir das obras principais e aspectos fundamentais do pensamento político e historiográfico de Oliveira Lima, traça paralelos com seu momento de vida e conjuntura política e cultural. Relato esclarecedor e muito bem construído, apesar de parecer ainda, como em Freyre, um esforço de justificativa dos atos e percalços da trajetória de Oliveira Lima.

Fernando da Cruz Gouvêa faz uma biografia extensa e meticulosa, bastante descritiva, chegando a adentrar nos pormenores da vida do biografado. Talvez, justamente por este detalhamento, é obra difícil de ser superada em sua completude. É interessante enquanto uma espécie de "enciclopédia e guia" da trajetória de Oliveira Lima, a ser consultada pontualmente.

Cerca de vinte e cinco anos depois da obra de Gouvêa, Teresa Malatian retoma os estudo sobre Oliveira Lima com sua tese de livre-docência. Busca explicar os espaços e campos de sociabilidade no qual Oliveira Lima estava inserido. Busca também estudar a atividade historiográfica do autor, centrada sobretudo na questão da narrativa da identidade nacional, abordagem que a autora cumpre de forma contundente. Interessante por conseguir articular as diversas facetas de Oliveira Lima (historiador, diplomata, "homem de letras", jornalista) em um "uno" que faz sentido em conjunto e esclarece diversas dúvidas advindas da sua intrínseca complexidade. É um excelente estudo, talvez um dos que mais contribuiu na

\footnotetext{
${ }^{32}$ MOTA, Carlos Guilherme. Oliveira Lima e nossa formação. In: História e Contra-História: perfis e contrapontos. São Paulo: Editora Globo, 2010.

${ }^{33}$ FORSTER, Maria Thereza Diniz. Oliveira Lima e as Relações Exteriores do Brasil. Brasília: FUNAG, 2011.

${ }^{34}$ VELLOZO, Júlio Cesar de Oliveira. Op.Cit. 2012.
} 
compreensão do nosso personagem. Observo apenas o recorte temporal no momento de sua trajetória em que esteve Oliveira Lima atuante na carreira diplomática. Talvez este recorte se explique por este ser o período em que o biografado esteve mais intensamente interligado em suas redes de sociabilidade (seja ela diplomática, política ou cultural-literária), prerrogativa de análise para o metodologia adotada pela autora.

Pretendemos aqui neste trabalho dialogar com Malatian em sua abordagem sobre Lima, sobretudo no que tange às interrelações entre as idéias do intelectual e suas redes de sociabilidade. Buscaremos avançar nas pesquisas no sentido de estudar a atividade de divulgação do Brasil no exterior de Lima, citada porém pouco explorada pela autora em sua obra.

Sintetizarei a seguir os três textos selecionados da edição da Revista Remate de Males dedicada à Oliveira Lima. Primeiramente, o texto "Um paladino da monarquia na imprensa republicana" de Antonio Arnoni Prado, traz um relato específico do momento em que OL passa pela polêmica causada por suas declarações monarquistas (1913) e acaba por se consumar em sua aposentadoria da "carrière diplomatique". Artigo construído como uma sequência de eventos a partir das repercussões do caso em publicações jornalísticas do período, é interessante enquanto "triller" dos acontecimentos e das disputas políticas entre monarquistas e republicanos e dos desentendimentos entre Oliveira Lima e Rio Branco. Acaba por encaminha o leitor a uma análise eminentemente política e personalista da situação, o que é interessante enquanto fotografia a ser devidamente situada no quadro geral da trajetória de Oliveira Lima, mas acaba por limitar a complexidade de Lima.

Ângela de Castro Gomes, em seu "Rascunhos de história imediata: de monarquistas e republicanos em um triângulo de cartas", faz uma análise, a partir de documentação epistolar, das redes de relacionamento estabelecidas entre Joaquim Nabuco, Rio Branco e Oliveira Lima. A autora vai, ao longo do texto, mostrando as mudanças ocorridas nos níveis de sociabilidade entre os três diplomatas e também nas suas mudanças de visão de mundo ao longo do tempo. Interessante para se aprofundar na questão dos relacionamentos pessoais dos três, assim como nas disputas políticas e diplomáticas do período.

Já o diplomata Paulo Roberto de Almeida, em seu "Oliveira Lima e a diplomacia brasileira no início da República: um intelectual com idéias fora do lugar ou com propostas fora da época?", traz um texto focado no relacionamento (ou desentendimentos) entre 
Oliveira Lima e Rio Branco, principalmente centrado dentro das disputas e questões do Itamaraty, mas também reverberando nos espaços de sociabilidade literária como a ABL e o IHGB. É uma análise que busca, a partir das personalidades e ideias - por vezes "pioneiras", seguindo o autor - dos dois analisados, assim como a partir do contexto de disputas da época, explicar os desentendimentos e, de certa forma, relativizar a questão dos desentendimento. A partir desta abordagem "pacificadora", o autor abre espaço para que Oliveira Lima seja readmitido enquanto personagem a ser estudado e instrumentalizado pelo Itamaraty.

Antônio Arnoni Prado volta a estudar Lima em 2010 a partir de seu artigo Dois Letrados e o Brasil Nação. No texto, trata de estabelecer comparações entre as visões de Brasil de Oliveira Lima e Sérgio Buarque de Holanda, considerados pelo autor como intelectuais paradigmáticos a fim de compreender dois momentos distintos e subsequentes da história intelectual brasileira. O livro homônimo de 2015 é, na realidade, um aprofundamento dos argumentos e idéias apenas apresentadas no artigo.

Consideramos o trabalho de Prado paradigmático em termos de sua interpretação sobre a visão de Brasil de Oliveira Lima e, assim, pretendemos dialogar com o autor de modo a estender sua argumentação ao caso específico estudado por este trabalho.

O historiador Carlos Guilherme Mota busca traçar um perfil psicológico e formativo de Oliveira Lima enquanto intelectual, além de pincelar uma análise sobre a importância e lugar de sua produção historiográfica. Interessante para a compreensão do perfil e a visão de Oliveira Lima enquanto historiador e intelectual. Sua contribuição vai no sentido de trazer algumas reflexões que de certa forma não haviam sido contempladas por Malatian em sua análise.

A diplomata Maria Theresa Diniz Forster - talvez possibilitada pelo texto do colega de carreira Paulo Roberto de Almeida - apresenta uma espécie de revisão do Itamaraty sobre Oliveira Lima, objetivando destacar sua importância para a diplomacia brasileira e, consequentemente, legitimando o MRE a valer-se de sua memória quando da construção de seu discurso e narrativa histórica. Constrói o trabalho a partir de uma visão da história que sustenta a relevância de Oliveira Lima a partir de seu legado derivado do pioneirismo de algumas de suas ideias (como pan-americanismo e integração latino-americana, divulgação cultural do Brasil no exterior a partir de uma "diplomacia cultural", pacifísmo e a tradição pacifista do MRE, dentre outras) parecendo incorrer assim no que Skinner em seu texto 
"Significação e compreensão na história das ideias" identifica como o equívoco da clarividência advindo da Mitologia das Doutrinas.

Isto significa que se crê que Oliveira Lima, enquanto diplomata, enunciou uma determinada doutrina diplomática (como as descritas acima) e que cabe ao historiador encontrar esta doutrina nas suas afirmações. Isto acaba por enquadrar Oliveira Lima em um tipo ideal de doutrina, o que leva a crer no pioneirismo destas doutrinas enunciadas por ele, como se estivesse antecipando determinadas ideias. Vale ressaltar também que esta prática leva a anacronismos, uma vez que atribui a Oliveira Lima certas ideias que ele não poderia ter defendido em sua época, simplesmente por não estar na pauta (nem no léxico) do período em que viveu, além do perigo de se procurar nos seus textos certas ideias que a priori se quer encontrar.

Aponto tais considerações de modo a contribuir para a continuidade das pesquisas a respeito do tema sob de uma perspectiva diferente. Considero esta obra importante por apresentar uma visão de diplomatas sobre Oliveira Lima, e sobretudo por levantar a questão da divulgação do Brasil no exterior, anteriormente ainda não abordada em profundidade por outros autores. Pretendo, entretanto, elaborar a pertinente questão devidamente cercado de um aparato metodológico que considero mais apropriado para sua análise. É talvez uma das motivações centrais desta pesquisa o reposicionamento da questão em diferente chave interpretativa.

Por fim, a dissertação de Mestrado de Júlio Cézar de Oliveira Vellozo para o programa de pós-graduação em Culturas e Identidades Brasileiras desenvolvido neste Instituto de Estudos Brasileiros da Universidade de São Paulo, prioriza a analise de Oliveira Lima enquanto historiador em busca de construir uma narrativa da nacionalidade brasileira. Tal narrativa tratava de valorizar o papel da colonização portuguesa e salientar alguns elemento distintivo da tradição brasileira como as transições políticas pactuadas e a ausência de rupturas com relação à Portugal.

Para isto busca compreender o contexto no qual o autor escreveu suas obras, além de relacionar aspectos da trajetória e da obra do autor, de modo a tentar torná-la mais clara. Ideia fundamental que percorre todo o estudo é a de que Oliveira Lima era um historiador cuja base intelectual pessoal era povoada por um imaginário Arcadista enquanto seu ambiente intelectual estava imerso em um imaginário Naturalista. 
É uma análise interessante e elucidativa da visão de Oliveira Lima enquanto historiador, tendo o mérito de avançar na análise e em questões propostas por Carlos Guilherme Mota. Entretanto, assim como a obra de Teresa Malatian em seu recorte diplomático, a obra de Vellozo tem suas limitações no recorte delimitado no Oliveira Lima enquanto historiador, absolutamente justificável dado os objetivos do estudo.

Vale ressaltar a importância da dissertação de Velloso enquanto espécie de precursora dos estudos de Oliveira Lima neste IEB-USP e enquanto proposta metodológica a partir de abordagens da História das Idéias para análise dos discursos do historiador.

Pretendemos dialogar com Vellozo ao propor um estudo que, de alguma maneira, aborda a obra de Oliveira Lima sob perspectiva metodológica semelhante. Buscaremos, entretanto, avançar nos estudos ao propor um analise conjunta de Oliveira Lima enquanto intelectual e diplomata, e não apenas enquanto historiador. Procuraremos avançar também ao estudar obras de Lima não analisadas por Vellozo quando de sua dissertação.

Apresentado o objeto, hipóteses, objetivo, metodologia e justificativa do presente trabalho, cabe, por fim, apresentar a maneira como será estruturado o estudo.

Questão fundamental levantada repetidas vezes pelas mais diversas definições e abordagens teórico-metodológicas apresentadas nesta introdução é a compreensão da cultura dos conjuntos de idéias, "sistemas de valores", "visões de mundo", da "idéia de Brasil" - de determinado contexto e seus diversos atores enquanto fator fundamental tanto da compreensão dos discursos proferidos por intelectuais quanto para a análise da política externa dos Estados a partir do paradigma da dimensão cultural nas Relações Internacionais.

Neste trabalho - vale ressaltar - a cultura é mais do que fator a influenciar a política externa. Trata-se de "instrumento" de política externa, o que torna ainda mais premente e fundamental sua compreensão de maneira problematizada e contextualizada. Assim, à tarefa de compreender as "idéia de Brasil", ou melhor, a questão da nacionalidade na ambientação da cena intelectual e das ideais em circulação no Brasil do início do século XX, será dedicado o primeiro capítulo deste trabalho.

A seguir, será desenvolvido um segundo capítulo com a intenção de explorar a rede de sociabilidade intelectual e as instituições políticas e produtoras de conhecimento nas quais Oliveira Lima circulava, de modo a compreender suas dinâmicas e pautas, atores e posicionamentos. Buscaremos articular a elas a visão de Oliveira Lima sobre a questão da 
nacionalidade tratando de compreender seus posicionamentos em relação às questões postas por sua rede e pelas instituições. Assim, em momentos diversos do capítulo, iremos nos debruçar sobre o Instituto Histórico e Geográfico Brasileiro (IHGB), a Academia Brasileira de Letras (ABL), o Ministério das Relações Exteriores (Itamaraty), todos em articulação no contexto dos anos iniciais do século XX.

Um terceiro capítulo virá com o objetivo de nos debruçarmos em profundidade sobre o objeto do trabalho: a atividade de divulgação do Brasil no exterior entre 1908 e 1912. Buscaremos analisar os argumentos internos ao discurso, de modo a compreender as nuances argumentativas. Buscaremos também extrapolar os textos em seus contextos: nas cenas na qual se desenrolam, seus atores, seus cenários, as conexões com demais textos e as repercussões e recepções dos discursos. Faremos também um reflexão sobre o sentido da atividade de divulgação do Brasil no exterior, buscando articular questões vistas ao longo do trabalho, ou melhor, vamos procurar retomar os mecanismos e articulações das questões postas pelo trabalho de modo a avaliar as possibilidades e os limites das hipóteses propostas. Finalmente, buscaremos dar conta de explicar como se deu o encerramento do processo em estudo.

Anexo ao trabalho disponibilizamos a transcrição de duas Conferências pronunciadas pro Oliveira Lima nesta sua atividade: "Sobre a evolução de uma cidade do Novo Mundo do XVI ao XX século" e "A lingua portugueza". Encontramos tais fontes publicadas nas paginas do jornal O Estado de São Paulo. Achamos por bem dar acesso ao leitor alguns exemplos de conferências, de modo a tornar mais esclarecedora e interessante a leitura do trabalho. Outro incentivo para transcrevê-las surgiu das dificuldades que nos deparamos durante a pesquisa: o acesso à esta fonte aqui transcrita se dá somente por copias digitalizadas em baixa resolução pelo próprio grupo jornalístico. Esperamos com isto oferecer nossa contribuição aos futuros pesquisadores. 


\title{
Capítulo 1 - Buscando Oliveira Lima em seu contexto intelectual
}

Oliveira Lima chegara para assumir seu posto de Ministro Plenipotenciário do Brasil na Legação em Bruxelas. Era 2 de março de 1908 quando despachou seu ofício ao chanceler Barão do Rio Branco, no comando do Itamaraty:

\author{
Senhor Ministro, \\ Tenho a honra de confirmar o seguinte telegrama que acabo de expedir a V. Ex.a: \\ Assumi Legação \\ Efetivamente, havendo chegado ontem a esta capital, tomei hoje conta da Legação \\ para a qual me designou a benevolência do Governo e que se achava interinamente a \\ cargo do seu Secretário Veloso Rebelo. Cumpre-me acrescentar que procurarei o \\ mais rápido possível corresponder neste posto à confiança de V. Ex.a. \\ Aproveito com prazer esta primeira oportunidade de apresentar a V. Ex.a as \\ seguranças da minha respeitosa consideração. \\ M. de Oliveira Lima ${ }^{35}$
}

Foi neste posto, entre 1908 e 1912, data de sua aposentadoria da carreira diplomática, que Oliveira Lima exerceu com maior intensidade a atividade de divulgação do Brasil no exterior, objeto de análise deste trabalho. Entretanto, antes de nos debruçarmos sobre as divulgações, esforço para o qual reservamos o Capítulo 2, é necessário entendermos um série de questões preliminares.

Quem era este Oliveira Lima que acaba de assumir a Legação de Bruxelas? Como havia sido sua trajetória diplomática até ali? E sua trajetória intelectual, enquanto Homem de Letras? Quais eram as redes de sociabilidade intelectual nas quais Oliveira Lima circulava? Quem eram seus interlocutores e em quais instituições se estabeleciam os diálogos e disputas? Quais eram as pautas teóricas e políticas que se discutiam e quais eram as posições de Oliveira Lima nessas pautas? Quais eram as principais idéias que circulavam nesses ambientes? Enfim, qual havia sido a trajetória e qual era o contexto intelectual no qual nosso diplomata estava inserido quando de sua chegada em Bruxelas? Estas são algumas das questões a que nos propomos explorar neste Capítulo 1.

Optamos por partir das questões mais contextuais e, a partir delas, ir pincelando com considerações mais específicas sobre o Oliveira Lima. Ou seja, pretende-se aqui desenvolver reflexões que visem esclarecer o "conjuntos de idéias", "sistemas de valores" e "visões de

\footnotetext{
${ }^{35}$ Ofício n 6 (1a Seção), Bruxelas, 2 de março de 1908, Arquivo Histórico, Ministério das Relações Exteriores
} 
mundo" da intelectualidade brasileira de então, assim como esclarecer as posturas de Oliveira Lima e seus pares neste contexto.

\section{1 - Algumas idéias fundamentais do ambiente naturalista: Evolucionismo e Civilização}

Entendemos que uma primeira questão a que devemos nos dedicar é a explorar um dado "conjunto de idéias" presente naquele contexto. Trata-se daquilo que Sílvio Romero, autor de "História da Literatura Brasileira"36, chamou de "bando de idéias novas": idéias como o positivismo, o darwinismo social e o evolucionismo. As consequências desses modos de pensar são relevantes, sobretudo do ponto de vista politico e da estrutura de pensamento dos intelectuais brasileiros do período.

Vale colocarmos a reflexão que Renato Ortiz fez sobre o tema, logo nos primeiros capítulos de seu "Cultura Brasileira e Identidade Nacional”. Os trecho que iremos reproduzir a seguir são longos, porém, bastante esclarecedores. Vamos a eles:

(...) em torno de 1870 , Sílvio Romero arrola uma lista de teorias que teriam contribuído para a superação do pensamento romântico. Dentre elas, três tiveram um impacto real junto à intelligentsia brasileira, e de certa forma, delinearam os limites no interior dos quais toda a produção teórica da época se constituiu: o positivismo de Comte, o darwinismo social, o evolucionismo de Spencer. Elaboradas na Europa em meados do século XIX, essas teorias, distintas entre si, podem ser consideradas sobre um único aspecto: o da evolução histórica dos povos. Na verdade, o evolucionismo procurava encontrar um nexo entre as diferentes sociedades humanas ao longo da historia; aceitando como postulado que o "simples" ( povos primitivos) evolui naturalmente para o mais "complexo" (sociedades ocidentais), procurava-se estabelecer as leis que presidiram o progresso das civilizações. ${ }^{37}$

Vemos que estas teorias - em especial o evolucionismo - buscam comparar os diferentes sociedades ao longo de seus processos históricos, tendo como base para esta comparação a idéia de que as sociedades evoluem naturalmente da mais primitiva para a mais complexa, da mais "inferior" para a mais "evoluída". este pensamento tem consequências políticas relevantes.

Do ponto de vista político, tem-se que o evolucionismo vai possibilitar à elite europeia uma tomada de consciência de seu poderia que se consolida com a expansão mundial do capitalismo. Sem querer reduzi-lo a uma dimensão exclusiva,

\footnotetext{
${ }^{36}$ ROMERO, Silvio. História da Literatura Brasileira. Rio de Janeiro: Garnier, 1888.

${ }^{37}$ ORTIZ, Renato. Cultura Brasileira e Identidade Nacional. São Paulo: Editora Brasiliense, 1985. p.14.
} 
pode-se dizer que o evolucionismo, em parte, legitima ideologicamente a posição hegemônica do mundo ocidental. A "superioridade" da civilização europeia torna-se assim decorrente das leis naturais que orientam a historia dos povos. ${ }^{38}$

Assim, mais do que a ideia de que existe uma sociedade - ou civilização, como se dizia - "inferior" e outra "superior", há a consolidação da idéia de que a sociedade europeia é, por conta das leis naturais do evolução, a civilização superior. Isto tem um peso grande no imaginário dos intelectuais brasileiros do período e os leva a pensar de maneira bastante específica.

A "importação" de uma teoria dessa natureza não deixa de colocar problemas para
os intelectuais brasileiros. Como pensar a realidade de uma nação emergente no
interior desse quadro? Aceitar as teorias evolucionistas implica analisar-se a
evolução brasileira sob as luzes das interpretações de uma história natural da
humanidade; o estágio civilizatório do país se encontra assim de imediato definido
como "inferior" em relançar à etapa alcançada pelos países europeus. Torna-se
necessário, por isso, explicar o "atraso" brasileiro e apontar para um futuro próximo,
ou remoto, a possibilidade de o Brasil se constituir como povo, isto é, como nação.
(...) Se o evolucionismo torna possível a compreensão mais geral das sociedades
humanas, é necessário porem completá-lo com outros argumentos que possibilitem o
entendimento da especificidade social. O pensamento brasileiro vai encontrar tais
argumentos em duas noções particulares: o meio e a raça.
Os parâmetros raça e meio fundamentam o solo epistemológico dos intelectuais
brasileiros de fins do século XIX e início do século XX. A interpretação de toda
história brasileira escrita no período adquire sentido quando relacionada a esses dois
conceitos chave.

Nos parece que de fato o pensamento evolucionista teve impactos sobre a intelectualidade brasileira, e que interpretar as questões que a teoria trazia consigo levou a reflexões sobre a especificidade brasileira a partir dos conceitos chave de raça e meio. Euclides da Cunha, Nina Rodrigues e Silvio Romero nos parecem exemplos - citados, inclusive, por Ortiz - dessas questões.

O próprio Oliveira Lima, de certo modo, em dado momento de sua trajetória ainda pensava dessa maneira. Colocamos deste modo porque, como veremos mais adiante neste trabalho, há no início do século XX uma inflexão em seu pensamento. Por hora, nos interessa que em sua experiência a partir de 1896 na Legação do Brasil em Washington, Estados Unidos, seu terceiro posto no serviço diplomático - os primeiros haviam sido Lisboa e Berlim - Oliveira Lima escreve a obra "Nos Estados Unidos. Impressões Políticas e Sociais", publicada em 1899.

$\mathrm{Na}$ obra procura analisar a sociedade americana e compará-la à sociedade brasileira e às sociedades européias. Para tal, não deixa de se valer como base de pensamento da teoria

\footnotetext{
${ }^{38}$ Ortiz, Renato. Op. Cit., 1984. p.15.
} 
evolucionista e dos parâmetros de raça e meio. Sua conclusão, naquele momento, coloca os Estados Unidos num estágio evolutivo entre o Brasil e a Europa, e suas reflexões trazem elementos que hoje poderiam ser lidos como preconceituosos.

Vamos continuar nossa reflexão sobre algumas teorias e conceitos fundamentais para o entendimento do pensamento dos intelectuais brasileiros do período. Como vimos, se pensava que haviam sociedades mais evoluídas do que outras. Neste mesmo sentido, entendemos que a idéia fundamental a compreender se encontra nos conceitos de "civilização" e "barbárie", ou melhor, na idéia de distinção entre "nós, civilizados" e "eles, bárbaros", marcadamente presente no período e em cujo contexto mais amplo se inserem os imperialismos europeus.

Mais do que isso, nos interessa aqui entender de que maneira estes conceitos se aplicam à compreensão e à interpretação das nações. Ou seja, nos interessa aqui entender de que maneira operam e quais são as conseqüências intelectuais e políticas dos conceitos de "nação civilizada" e "nação bárbara".

De modo a problematizar a conceituação desta idéias, vamos nos valer da análise de Immanuel Wallerstein a respeito da questão retórica, da dimensão dos valores difundidos e intrínsecos a certos discursos. Este exercício vem no sentido de discutir a questão da imposição da civilização e do progresso e do processo de ocidentalização por parte dos países centrais aos países periféricos do "sistema-mundo".

Cabe aqui a este trabalho analisar esta questão - sobretudo a partir da obra "O Universalismo Europeu: a retórica do poder"139 - a ser estudada com maior detalhamento nos parágrafos a seguir a fim de que se compreenda este processo. Com isto, espera-se oferecer uma visão sistêmica sobre como a idéia de "civilização" passou a ter centralidade nos "sistemas de valores" do sistema cultural brasileiro do contexto do início do século XX.

A obra trata da retórica do "Universalismo Europeu", um discurso pronunciado pelos líderes dos países centrais em cujo argumento central é o apelo ao universalismo - um específico e construído conjunto de valores - como justificativa para suas políticas direcionadas a países periféricos do "sistema-mundo moderno". ${ }^{40}$

Como se observa, as reflexões de Wallerstein sobre o "Universalismo Europeu" se inserem numa perspectiva mais ampla de seu pensamento a respeito do "sistema-mundo

\footnotetext{
${ }^{39}$ WALLERSTEIN, Immanuel. Op. Cit. 2007.

${ }^{40}$ WALLERSTEIN, Immanuel. Op. Cit. 2007. p.26.
} 
moderno". Trata-se de um esforço de historicizar o discurso, ou seja, de compreender os elementos de uma retórica específica inserida em um contexto mais amplo, encaixado e operando em uma certa estrutura histórica: o "sistema-mundo moderno". ${ }^{41}$ Wallerstein considera que:

\begin{abstract}
a história do sistema-mundo moderno tem sido, em grande parte, a história da expansão dos povos e dos Estados europeus pelo resto do mundo. Essa é a parte fundamental da construção da economia-mundo capitalista. Na maioria das regiões do mundo, essa expansão envolveu conquista militar, exploração econômica e injustiças em massa. ${ }^{42}$
\end{abstract}

Este processo configurou lugares específicos para os diversos países dentro da lógica sistêmica, em cujas relações internacionais operam. A partir desta constatação, pode-se dizer que Wallerstein considera que o Sistema Internacional se configurou a partir de uma lógica sistêmica específica, intimamente ligada historicamente a esta "expansão dos povos e dos Estados europeus pelo resto do mundo".

Dentre os diversos lugares no sistema-mundo, cabe aos países europeus - juntamente com os Estados Unidos a partir de meados do século XX, ao alcançar uma nova posição no sistema - o lugar de países centrais, hegemônicos, capazes de exercer poder e em cujas políticas visam ao interesse de manutenção deste poder. Por outro lado, cabe aos países não europeus, ao "resto do mundo", os lugares periféricos ou semi-periféricos, daqueles que tem pouca ou praticamente nenhuma capacidade de exercer poder e, portanto, de impor seus interesses no sistema-mundo. ${ }^{43}$

Vale ainda ressaltar que dentro deste "sistema-mundo moderno" opera a "economiamundo capitalista", sistema econômico cujo princípio fundamental é a acumulação incessante de capital, interesse central portanto do capital advindo dos países centrais. Além dos interesses especificamente centrados no poder político, a questão econômica é portanto mais um elemento de interesse dos países centrais a direcionar suas políticas. Decorre destes interesses a lógica também sistêmica da "economia-mundo capitalista", da divisão internacional do trabalho:

\footnotetext{
${ }^{41}$ WALLERSTEIN, Immanuel. Op. Cit. 2007. p.122.

42 WALLERSTEIN, Immanuel. Op. Cit. 2007. p.29.

${ }^{43}$ Vale aqui pontuar que temos consciência das atuais transformações no sistema-mundo, principalmente no que tange às perspectivas de uma nova balança de poder, sobretudo a partir da ascensão chinesa. Entretanto, não cabe a este trabalho estudar estas questões, restringindo-nos aqui apenas às observações de Wallerstein sobre a retórica do "Universalismo Europeu".
} 
(...) uma divisão axial de trabalho entre processos de produção centrais e periféricos, regulamentada por uma rede de Estados soberanos que funcionam dentro de um sistema inter-estados. ${ }^{44}$

Feita a digressão teórica sobre o "sistema-mundo moderno" e a "economia-mundo capitalista", voltemos à questão central proposta para este breve estudo: a retórica do "Universalismo Europeu”. Tal retórica pode ser encarada, segundo o autor, enquanto uma espécie de estrutura cultural-intelectual complementar às estruturas especificamente políticas e econômicas de poder. ${ }^{45} \mathrm{Ou}$ seja, a retórica do "Universalismo Europeu pode ser encarada enquanto estrutura cujo o intuito é trabalhar no campo das mentalidades, do imaginário, das visões de mundo e dos valores, de modo a influenciar os países periféricos a acatarem as políticas dos países centrais.

Neste sentido, os países centrais se valeram durante seu processo de expansão pelo mundo de três tipos principais de apelo ao universalismo como forma de justificar suas políticas direcionadas a países periféricos: 1) o argumento de que suas políticas - inclusive e principalmente suas intervenções militares - são empreendidas com o intuito de defender e promover "valores universais" tais como "direitos humanos" e "democracia"; 2) o fato de a civilização "ocidental" ser superior às "outras" civilizações pelo fato de ser a única baseada em valores e verdades universais. Isto faz com que os países centrais, pertencentes à "civilização ocidental", tenham uma espécie de "missão civilizadora" perante os outros países; 3) a afirmação da superioridade da verdade científica perante as demais maneiras de se definir e chegar à verdade ${ }^{46}$ faz com que seja superior a verdade científica. A isto se aplica a verdade cientificadas leis do livre mercado - das leis cientificamente provadas da economia neoliberal - de modo que não haja alternativa aos governos, principalmente os periféricos, a não ser aceitar e agir de acordo com estas leis. ${ }^{47}$

\footnotetext{
44 WALLERSTEIN, Immanuel. Op. Cit. 2007. p.88-89.

45 WALLERSTEIN, Immanuel. Op. Cit. 2007. p.89.

46 Note que esta constatação da superioridade da verdade científica vale para o mundo contemporâneo. Entretanto, por exemplo durante o processo de expansão dos países europeus pelo mundo - sobretudo nos séculos XVI e XVII - esta mesma lógica foi utilizada no sentido de demonstrar a inevitabilidade de determinada política dada a superioridade da verdade teológica.
}

${ }^{47}$ WALLERSTEIN, Immanuel. Op. Cit. 2007. p.26. 
Todos os três argumentos tem como base, como pressuposto, a justificativa de que as ações e políticas empreendidas pelos países centrais em sua expansão e intervenções pelo mundo visam o bem maior, algo que pudesse ser encarado como positivo para todos. ${ }^{48} \mathrm{Com}$ isto, certas noções como "civilização" ou "progresso" são vistas como contribuições dos países centrais para o mundo periférico e "bárbaro", vistas como a expansão de "valores universais", benéfico e inevitável a todos:

(...) Os que lideraram e mais lucraram com ela justificam-na a seus olhos e aos do mundo com base no bem maior que representou para todos os povos. $\mathrm{O}$ argumento mais comum é que tal expansão disseminou algo invariavelmente chamado de civilização, crescimento e desenvolvimento econômico ou progresso. Todas essas palavras foram interpretadas como expressão dos valores universais, incrustados no que se costuma chamar de lei natural. Por isso, afirmou-se que essa expansão não só foi benéfica para a humanidade como também historicamente inevitável. ${ }^{49}$

São estes valores, encarados e construídos pelos países centrais europeus enquanto "valores universais" que Wallerstein denomina "Universalismo Europeu".

Nas últimas páginas apresentamos em linhas gerais algumas teorias, conceitos e questões levantadas por Ortiz e Wallerstein. vale agora a este estudo aplicar tais argumentos retóricos ao contexto histórico específico do início do século $\mathrm{XX}$, mais especificamente ao período da Belle Époque, fase final do "longo século XIX" e fase de transição hegemônica da Europa para a América do Norte, precisamente da Grã-Bretanha para os Estados Unidos.

Observa-se de fato neste período elementos discursivos como "civilização", "progresso", "modernidade" e "liberdade econômica" encarados enquanto valores universais e sobretudo enquanto elementos notadamente de origem européia, pertencentes à "civilização ocidental", centrados enquanto modelo político-econômico em Londres e enquanto modelo cultural em Paris. Entendia-se de fato a superioridade destes "valores universais" e vinha daí o sentimento de "missão civilizadora" dos países centras diante da "barbárie" de certos países periféricos, sobretudo das Américas e da África.

Cabe aqui notar que mesmo diante de alguns países periféricos reconhecidos pelos países centrais como "não bárbaros" e advindos de alguma espécie de "civilização" - como o caso da China na expansão européia do século XIX por exemplo - os europeus assumiam a

\footnotetext{
48 Note que apesar de a expansão dos países centrais pelo mundo ser um fenômeno não mais em curso como o foi dos séculos XVI ao XIX, suas intervenções ainda o são e, sobretudo, sua retórica de justificativa continua a ser empreendida.
}

49 WALLERSTEIN, Immanuel. Op. Cit. 2007. p.29-30. 
superioridade da "civilização ocidental" diante das "outras civilizações" pelo fato de ser o único a ser baseado em valores e verdades universais. ${ }^{50}$

Entendemos que a elite política e cultural brasileira do período, como já havíamos adiantando, de certa forma comungava desta visão de mundo. Evidentemente tal visão de mundo por parte das elites brasileiras deve ser relativizada a partir do questão da intencionalidade por parte dos países centrais de que a elite brasileira pensasse desta maneira, por conta de todas os elementos já levantados por Ortiz e Wallerstein.

Assim, feita a contextualização das "visões de mundo" ou "sistema de idéias" comungadas pelos intelectuais brasileiros inseridos num ambiente naturalista, acreditamos que podemos avançar nas análises mais específicas sobre o ambiente intelectual brasileiro do contexto.

\section{2 - Reflexões sobre o contexto intelectual brasileiro do final do XIX e início do XX}

Recorremos logo de início à dissertação de Julio Vellozo ${ }^{51}$. Nela, partindo de uma fundamentação metodológica baseada no conceito de "vidobra" de François Dosse ${ }^{52}$, Velloso busca inicialmente compreender o contexto no qual Oliveira Lima estava inserido, para daí buscar relações com a trajetória da vida e obra do historiador.

Eis aqui uma diferença fundamental entre os esforços de Vellozo e os nossos: aqui nos focamos no Oliveira Lima diplomata, sem esquecer sua intrínseca conexão com o Oliveira Lima enquanto Homem de Letras; Vellozo se foca no Oliveira Lima enquanto historiador e Homem de Letras, buscando compreender o processo de construção de sua narrativa da nacionalidade brasileira. Nos parece, entretanto, que o esforço de compreender o contexto, suas questões, desafios e respostas, assim como uma série de outras constatações mais específicas sobre a trajetória de Oliveira Lima, nos são convergentes, daí nossa opção de partir dos seus escritos.

\footnotetext{
${ }^{50}$ WALLERSTEIN, Immanuel. Op. Cit. 2007. p.66.

${ }^{51}$ VELLOZO, Júlio Cesar de Oliveira. Um Dom Quixote gordo no deserto do esquecimento. Oliveira Lima e a construção de uma narrativa de nacionalidade. 2012. 219 p. Dissertação (Mestrado em Culturas e Identidades Brasileiras) - Instituto de Estudos Brasileiros, Universidade de São Paulo, São Paulo.

${ }^{52}$ DOSSE, François. O Desafio Biográfico: escrever uma Vida. São Paulo: Edusp, 2009.
} 
$\mathrm{Na}$ visão de Vellozo, haviam três elementos fundamentais naquele contexto: o ambiente naturalista, o espírito de missão dos intelectuais e uma pauta político-teórica reformista. Em suas palavras:

\begin{abstract}
Parece-nos que três elementos eram fundamentais para as vivências e relações estabelecidas pelos intelectuais entre si e com o mundo à sua volta: a) o forte ambiente naturalista, que criava uma sensação de vertigem do progresso e inevitabilidade do processo de modernização; b) o espírito de missão que a intelectualidade do período assumia, creditando a si o papel de orientar o processo de reformas, questão que se ampliaria com a decepção provocada pela experiência republicana; c) existência de uma pauta político-teórica reformista que tinha como sentido principal o encaminhamento do processo de formação da nação e consequentemente inserção do país na modernidade..$^{53}$
\end{abstract}

Vamos nas próximas páginas procurar explorar e problematizar, na nossa visão e com o auxílio de revisão bibliográfica pertinente, cada um destes elementos.

$\mathrm{Na}$ visão de Vellozo, o ambiente naturalista estava associado às sensações de "vertigem do progresso e inevitabilidade do processo de modernização". Vemos esta interpretação mais como uma consequência do ambiente e das idéias em circulação naquele contexto do que como um explicação de fato do que era o ambiente naturalista.

A discussão sobre o ambiente naturalista no Brasil é, no fundo, uma discussão sobre o contexto intelectual em que se inseria a intelectualidade da chamada Geração de 70, um movimento intelectual até certo ponto heterodoxo da elite letrada brasileira dos anos finais do Império. Compreender este contexto se faz importante para nos aproximarmos de Oliveira Lima. Este esforço vem no sentido de se compreender as aproximação e distanciamentos para com a geração posterior, da qual Oliveira Lima pertencia.

Vale aqui pontuar que Oliveira Lima se mudou com seus pais para Portugal quando tinha apenas 6 anos de idade e passou fase inicial de sua formação intelectual em seu Curso Superior de Letras de Lisboa, no qual teve contato mais direto com a Geração de 1870 lusitana e intelectuais como Oliveira Martins e Teófilo Braga. Posteriormente, em seu retorno ao Brasil, conviveu e estabeleceu diálogo em seus círculos com intelectuais da Geração de 1870 brasileira, a destacar Joaquim Nabuco por exemplo.

Um importante trabalho sobre a Geração de 70 é a obra de Angela Alonso, Idéias em Movimento: A geração 1870 na crise do Brasil-Império. Em sua análise, Alonso inicia por problematizar o que chamou de "diagnostico da imitação", ou seja, a percepção, inclusive por

\footnotetext{
${ }^{53}$ VELLOZO, Júlio Cesar de Oliveira. Op. Cit., 2012. p 31.
} 
parte de autores da época, de que as idéias dos pensadores brasileiros daquela geração imitavam pensamentos e modas européias de então como se fossem "réplicas nacionais de linhas de pensamento europeu".

O conceito operatório é a noção de "influência". O movimento intelectual (da Geração de 1870) aparece como feixe de réplicas nacionais de linhas de pensamento europeu, compondo "escolas de pensamento". ${ }^{54}$

Façamos uma pausa para lembrar de uma importante questão. Afinal, que linhas de pensamento são estas? Ora, as teorias como o evolucionismo e idéias como a de civilização que vimos no tópico anterior.

Voltemos para a discussão do "diagnóstico da imitação" de Alonso. Entendemos que a autora parte do pressuposto de que não havia no Brasil e nem mesmo na Europa, naquele momento, autonomia do campo intelectual em relação ao campo politico.

O pressuposto da autonomia do campo intelectual é de validade duvidosa para o Brasil na segunda metade do século XIX. A separação entre um campo politico e outro intelectual estava ainda em processo mesmo na Europa. (...)

Observando as trajetórias individuais e o conjunto de obras publicadas nos anos 1870 e 1880 é impossível distinguir "intelectuais" de "políticos". No Brasil da segunda metade do século XIX não havia um grupo social cuja atividade exclusive fosse a produção intelectual. ${ }^{55}$

Assim, o diagnóstico de Alonso de que não havia autonomia do campo intelectual em relação ao campo politico tem como consequência o fato de que:

(...) toda manifestação intelectual era imediatamente um evento politico. A experiência dos membros do movimento "intelectual" da geração 1870 era, pois, política.

(...)

Há uma complementariedade entre textos e formas de ação. Escritos e práticas se unificam politicamente. (...) Assim se vislumbra o sentido principal dos escritos do movimento da geração de 1870: eram formas de intervenção política. ${ }^{56}$

Dentro desta perspectiva de produção intelectual vinculada à ação política, o que os membros da Geração de 1870 faziam era selecionar deliberadamente teorias e conceitos do pensamento europeu - como os já citados positivismo, evolucionismo e darwinismo social como uma forma de subsidiar a compreensão da realidade brasileira e traçar de forma mais

\footnotetext{
54 ALONSO, Angela. Idéias em movimento: a geração de 1870 e a crise do Brasil-Império. São Paulo: Paz e Terra, 2002. p.23.

${ }^{55}$ ALONSO, Angela. Op. Cit., 2002. p.30.

${ }^{56}$ ALONSO, Angela. Op. Cit., 2002.p.38-39.
} 
eficiente ações políticas a serem adotadas. Ou seja, fazia-se uso de um repertório europeu como forma de ação política no Brasil.

Argumentos e conceitos de teorias estrangeiras não foram adotados aleatoriamente, sofriam um processo de triagem: havia um critério político de seleção. Os agentes elegeram um conjunto de teorias e noções por razões práticas: estavam em busca de subsídios para compreender a situação que vivenciavam e para desvendar linhas mais eficazes de ação política. ${ }^{57}$

De forma a caracterizar esta ação política no seu contexto histórico, Alonso evoca o conceito de "movimento intelectual de reformismo" uma vez que tratava-se de "um movimento de contestação à ordem imperial e de demanda por reformas estruturais" e que tem como exemplos os escritos abolicionistas e os escritos republicanos. ${ }^{58}$

Para Nicolau Sevcenko em seu Literatura como missão, os intelectuais do movimento que ele chama de "geração modernista de 1870" são interpretados, e fazem-se conhecer, enquanto "Mosqueteiros Intelectuais". Isto porque o "o engajamento (político) se torna condição ética do homem de letras".

A palavra de ordem (...) era condenar a sociedade "fossilizada" do Império e pregar as grandes reformas redentoras: "a abolição", "a república", "a democracia". (...) Todos eles trazem como lastro de seus argumentos as novas idéias européias e se pretendem os seus difusores no Brasil. ${ }^{59}$

A partir de discussões em vaga sobre a formação dos Estados-Nação e as condições para seu pleno desenvolvimento, os "Mosqueteiros Intelectuais" interpretam um conjunto de idéias vindos da Europa a partir das questões postas em pauta no Brasil. Nesta interpretação chegaram à conclusão de que o Brasil necessitava de uma modernização de sua estrutura social e política. A palavra de ordem era a construção da nação e o remodelamento do Estado.

Sem possuir propriamente uma nação e com um Estado reduzido ao servilismo politico, o Brasil carecia, portanto, de uma ação reformadora nesses dois sentidos: construir a nação e remodelar o Estado, ou seja, modernizar a estrutura social e política do país. (...) E foram ambos cingidos pelas duas correntes antípodas que assinalaram os modos de pensar da Belle Époque: o cientificismo e o liberalismo. ${ }^{60}$

Havia, entretanto, outras razões mais pragmáticas para a proposição de tais modernizações: tratava-se do temor de intervenções das potências imperialistas em seu

\footnotetext{
${ }^{57}$ ALONSO, Angela. Op. Cit., 2002. p.39.

58 ALONSO, Angela. Op. Cit., 2002. p.45.

59 SEVCENKO, Nicolau. Literatura como missão: Tensões sociais e criação cultural na Primeira República. $2^{\mathrm{a}}$ edição. São Paulo: Companhia das Letras, 2003. p.27.

60 SEVCENKO, Nicolau. Op. Cit., 2003. p.103.
} 
processo expansionista, questão a que voltaremos com maior aprofundamento mais adiante neste trabalho. Por hora, observemos que havia:

(...) o temor obsessivo extremamente difundido e sensível em todo tipo de escritor, de que o Brasil viesse a sofrer uma invasão das potências expansionistas, perdendo a sua autonomia ou parte do seu território. (...) O próprio Barão do Rio Banco iria imprimir à diplomacia brasileira uma orientação claramente defensiva no tocante a esse receio onipresente. ${ }^{61}$

Destaca-se também na análise de Sevcenko uma importante consequência desta atitude ao mesmo tempo reformadora e salvacionista: o interesse dos intelectuais em estudar de maneira mais aprofundada a realidade brasileira. "Uma ciência sobre o Brasil seria a única maneira de garantir uma gestão lúcida e eficiente de seu destino." 62

Como vimos, Alonso e Sevcenko, cada um a seu modo, chegam a conclusões bastante parecidas sobre a Geração de 1870: trata-se de movimento intelectual que se vale de idéias originalmente européias no sentido de uma ação política no Brasil.

Embora com o final do Império e a proclamação da República as questões se dêem de maneira diversa, como veremos, nos parece que os intelectuais dos anos iniciais da República - alguns remanescentes da Geração de 1870 em companhia de homens de letras mais jovens, como Oliveira Lima - compartilhavam daqueles elementos básicos que identificamos na Geração de 1870: "permaneciam nas mentes" aquelas idéias vindas da Europa e permanecia o sentimento de ação polícia no sentido de construção da nação.

Avancemos agora para o ambiente dos intelectuais nos anos iniciais da República. Nos parece importante, neste novo contexto, a análise do ponto de vista da crítica literária empreendida por Antonio Candido em seu Literatura e Cultura de 1900 a 1945.

Uma primeira questão apresentada pelo autor é a dialética entre o localismo e o cosmopolitismo, presente como uma espécie de lei para a literatura brasileira. Em suas palavras:

\footnotetext{
“Ora a afirmação premeditada e por vezes violenta do nacionalismo literário, com veleidades de criar até uma língua diversa; ora o declarado conformismo, a imitação consciente dos padrões europeus." 63
}

\footnotetext{
61 SEVCENKO, Nicolau. Op. Cit., 2003. p.104.

62 SEVCENKO, Nicolau. Op. Cit., 2003. p.105.

63 CANDIDO, Antonio. Literatura e cultura de 1900 a 1945. In: Literatura e Sociedade: estudos de teoria e história literária. 6a edição. São Paulo: Companhia Editora Nacional, 1980. p.109.
} 
Em alguns momentos as obras se concentram em questões e temáticas nacionais, no localismo; em outras se voltam para o exterior e copiam os seus padrões, sobretudo europeus. Assim, para Candido, aquilo que de melhor tem sido produzido, em termos literários, no Brasil, é resultado de um equilíbrio destas duas tendências, a partir de um processo dialético entre a substância de expressão, a temática nacional e a forma de expressão, o molde de tradição europeia.

Ainda para Candido, a literatura brasileira apresenta dois momentos decisivos, de virada em termos literários: o Romantismo (1836 a 1870) e o Modernismo (1922 a 1945). Ao período compreendido entre estes dois marcos chamou de Pós-Romantismo, cuja definição primordial é a de literatura de permanência, expressa pelo academicismo.

Conserva e elabora traços desenvolvidos depois do Romantismo, sem dar origem a desenvolvimentos novos; (...) Uma literatura satisfeita, sem angústia formal, sem rebelião nem abismos. Sua única mágoa é não parecer de todo européia; seu esforço mais tenaz é conseguir pela cópia o equilíbrio e a harmonia, ou seja, o academicismo. $^{64}$

Vale ainda destacar que o Pós-Romantismo tem como produto típico, na percepção de Candido, um texto em que as características principais são as de um:

(...) romance ameno, picante, feito com alma de cronista social para distrair e embalar o leitor. (...) Forma-se pela confluência do que há de mais superficial em Machado de Assis, da ironia amena de Anatole France e dos romances franceses do Pós-naturalismo, sentenciosos, repassados de sexualismo frívolo $(\ldots)^{65}$

São ainda deste período as transformações do que se denominava regionalismo pra aquilo que Candido chamou de "conto sertanejo (...) um meio de encarar com olhos europeus as nossas realidades mais típicas", e as poesias parnasianas e simbolistas.

Em crítica literária, notadamente organizada em torno de figuras como Sílvio Romero, Araripe Júnior e José Veríssimo, desenvolveu-se o que chamou de "crítica nacionalista" a partir do "critério de nacionalidade", “(...) tomando como elemento fundamental de interpretação e consistindo em definir e avaliar um escritor ou obra por meio do grau maior ou menor com que exprimia a terra e a sociedade brasileira." ${ }^{66}$

Vemos aí que mesmo Candido tendo interpretado este novo contexto - e de ponto de vista da diverso, diga-se - uma questão se destaca em consonância com as análises de Ortiz,

\footnotetext{
${ }^{64}$ CANDIDO, Antonio. Op. Cit., 1980. p.113.

${ }^{65}$ CANDIDO, Antonio. Op. Cit., 1980. p.113.

${ }^{66}$ CANDIDO, Antonio. Op. Cit., 1980. p.116.
} 
Alonso e Sevcenko: a questão da nacionalidade. Para uns é o critério que baseou a crítica literária daquele ambiente intelectual, para outros a questão que levava os intelectuais à reflexão sobre a realidade nacional e a ação política. No final das contas, o que se direcionava era a construção da nação, seja ele feita via literatura, seja ela feita via política. Ou melhor, nos parece que agora neste novo contexto Republicano a construção da nacionalidade se dá justamente como uma ação política via literatura.

Vale complementarmos a permanência da questão da nacionalidade com uma observação interessante feita foi Elias Thomé Saliba em seu artigo para a coletânea organizada por Sevcenko, História da Vida Privada no Brasil. República: da Belle Epoque à Era do Rádio. Para Saliba, aquele novo contexto envolvia a questão da nacionalidade e os intelectuais em uma série de dúvidas e contradições.

Toda a geração de intelectuais, jornalista e pensadores brasileiros que viu nascer a República esforçou-se para forjar um conhecimento sobre o Brasil em todas suas peculiaridades, pois aquele momento, que se seguiu ao advento da República, parecia uma rara, e talvez única, oportunidade histórica de o país se pôr no nível do século, integrando-se de uma forma definitiva no mundo ocidental. O advento da República e os efeitos combinados de uma nova expansão européia representavam uma esperança para as gerações de pensadores do início do século XX. Mas, dotados de um equipamento intelectual herdado das linhagens ideológicas positivistas e evolucionistas - equipamento este já originado de uma crise da racionalidade cognitiva -, acabariam oscilando entre a adoção de modelos deterministas e a reflexão sobre suas implicações ; entre a exaltação de uma "modernidade nacional" e a verificação de que o país, como tal, era inviável. Sem possuir propriamente uma nação, marcado por extremas diversidades regionais, convivendo com a chaga social do trabalho escravo como herança e com um Estado praticamente reduzido ao servilismos político, o país apresentava-se aos olhos desses intelectuais de um modo insólito e dramático: como construir uma nação se não tínhamos uma população definida ou um tipo definido? Diante daquela amálgama de passado e futuro, alimentado pela República, quem era o brasileiro?" 67

Vemos que Saliba salienta a permanência da angustia dos intelectuais brasileiros com a questão da especificidade nacional. Isto se dá pelo fato de, mesmo sob um novo regime político, as idéias - ou o que o autor chama de "equipamento intelectual" - permanecerem as mesmas: continua se pensando as questões sob as bases das linhagens positivistas e evolucionistas. Assim, não só as angustias permanecem, mas também permanece a questão da constituição da nacionalidade.

${ }^{67}$ SALIBA, Elias Thomé. A Dimensão Cômica da Vida Privada na República Brasileira. In: SEVCENKO, Nicolau. História da Vida Privada no Brasil. República: da Belle Epoque à Era do Rádio. São Paulo: Companhia das Letras, 2010. p. 296. 
Ainda nos estudos de crítica literária sobre o contexto, estudando o mesmo período compreendido entre o Romantismo e o Modernismo, Alfredo Bosi em seu Literatura Brasileira, Volume $V$ : O Pré-Modernismo interpreta uma "conotação temporal de anterioridade (e) um sentido de precedência temática e formal em relação à literatura modernista". 68

Do ponto de vista histórico-literário é um período cuja mentalidade é fundada num "complexo cultural do último quartel do século XIX", em cujos gêneros literários apresentam elementos de conservação estilística ao mesmo tempo que inauguram elementos de renovação, sobretudo no interesse pela compreensão da realidade nacional.

Um Euclides, um Graça Aranha, um Monteiro Lobato, um Lima Barreto injetam algo de novo na literatura nacional, na medida em que se interessam pelo que já se se convencionou chamar "realidade brasileira". ${ }^{69}$

Vemos novamente em Bosi para os anos iniciais da República o que Sevcenko havia observado para a Geração de 1870: mais do que a questão da construção da nacionalidade, havia um movimento no sentido de se aprofundar no entendimento realidade brasileira.

Avancemos. Uma interessante análise sobre os intelectuais dos anos iniciais da República é a de Sergio Miceli, em seu Poder, sexo e letras na República Velha: estudo clinica dos Anatolianos, onde se privilegia a análise das trajetórias sociais dos homens de letras do período. Nos parece que Miceli bourdisianamente busca compreender “(...) as condições sócio-históricas em meio às quais se constitui o campo intelectual (...)", 70

Novamente veremos que outro autor entende que não havia ainda se conformado uma autonomia do campo intelectual, de modo que as trajetórias intelectuais dos letrados estava ainda intimamente ligada a fatores políticos e sociais.

Não havendo, na República Velha, posições intelectuais autônomas em relação ao poder político, o recrutamento, as trajetórias possíveis, os mecanismos de consagração, bem como as demais condições necessárias à produção intelectual sob suas diferentes modalidades, vão depender quase que por completo das instituições e dos grupos que exercem o trabalho de dominação. ${ }^{71}$

68 BOSI, Alfredo. Literatura Brasileira, Volume V: O Pré-Modernismo. $3^{\text {a }}$ edição. São Paulo: Editora Cultrix, 1969. p.11.

69 BOSI, Alfredo. Op. Cit., 1969. p.12.

70 MICELI, Sergio. Poder, sexo e letras na República Velha: estudo clinica dos Anatolianos. In: Intelectuais à Brasileira. São Paulo: Companhia das Letras, 2008. p.16.

${ }^{71}$ MICELI, Sergio. Op. Cit., 2008. p.17. 
Seu estudo classifica e analisa diversos grupos de intelectuais conforme as suas posições de dominação. Para nós ganha destaque em sua análise o grupo que Miceli denominou de "grupo dos anatolianos":

(...) uma primeira forma de diversificação de papéis no âmbito do trabalho de dominação. (...) Os integrantes desse grupo prefiguram um tipo novo de intelectual profissional, assalariado ou pequeno produtor independente, vivendo dos rendimentos que lhes propiciam as diversas modalidades de sua produção, desde a assessoria jurídica, as conferências, passando pelas colaborações na imprensa, até a participação nos acontecimentos mundanos e nas campanhas de mobilização em favor do serviço militar, da alfabetização do ensino primário, etc. ${ }^{72}$

Outra característica importante dos "anatolianos" é a sua relação de dupla dependência, com relação à oligarquia local e em relação aos modelos europeus, "por serem obrigados a importar sistemas de pensamento capazes de legitimar sua posição interna $(\ldots) " \cdot 73$

Nota-se aqui, entretanto, uma diferença entre a chamada Geração de 1870 e os "anatolianos": enquanto que para aqueles o trabalho intelectual estava intimamente ligado ao trabalho político juntamente com sua posição de maior autonomia no campo do poder refletiam em uma "anglomania", entendida enquanto importação dos sistemas de pensamento, sobretudo políticos, ingleses, para os "anatolianos", vendo-se "a meio caminho entre os modelos fornecidos pela geração de 1870 e aqueles oferecidos pela vanguarda europeia da época (...)"74, acabavam por importar sistemas de pensamento franceses, em cujo modelo intelectual era o escritor Anatole France e em cuja fascinação por Paris se expressava pela "Galomania".75

Nos parece que Oliveira Lima mais ou menos se enquadraria, por alguns aspectos, na neste "grupo dos anatolianos": nosso intelectual é filho de uma descendente de importante família da aristocracia açucareira de Pernambuco com um rico comerciante português no Recife; é um diplomata recrutado por intervenção de um parente de sua mãe - com dependências com relação à oligarquia local, portanto - logo que conclui seus estudos no Curso Superior de Letras de Lisboa em Portugal, se configurando assim, no nosso entendimento em um intelectual profissional, assalariado do Itamaraty; e, por fim, nos parece

\footnotetext{
72 MICELI, Sergio. Op. Cit., 2008. p.54.

73 MICELI, Sergio. Op. Cit., 2008. p.59.

74 MICELI, Sergio. Op. Cit., 2008. p.60.

75 MICELI, Sergio. Op. Cit., 2008. p.62.
} 
também de certa forma dependente, ou ao menos atrelado aos modelos europeu de pensamento, se não tanto pela "galomania", certamente por afinidades com seus mestres da Oliveira Martins e Teófilo Braga da geração de 1870 lusitana.

Outra visão interessante sobre o contexto é a de Jeffrey Needell em sua obra Belle Époque tropical: Sociedade e Cultura de Elite no Rio de Janeiro na Virada do Século. Needel analisa o que denominou de Belle Époque literária e dá destaque para a questão da "fantasia da civilização" por parte da elite brasileira, uma aspiração claramente expressa a partir da literatura, sobretudo a de inspiração francesa.

As obras publicadas, naturalmente, sempre foram um elemento importante no meio da elite da capital. (...), a educação recebida pelos membros da elite era clássica, com grande ênfase literária. Conhecer a literatura, sobretudo a francesa, era a marca de um indivíduo bem-educado. Portanto, a familiaridade com as letras, os versos adolescentes e um respeito permanente pelos literatos eram comuns naqueles que pertenciam, ou aspiravam, à elite carioca. ${ }^{76}$

Sobre a questão da influência da literatura francesa, vale pontuar o fato de que mais do que simples cópias, os literatos brasileiros adaptavam a literatura fin-de-siècle à realidade nacional como uma forma de demostrar intimidade com as tendências em voga na França ao mesmo tempo que se colocavam enquanto produtores da cultura nacional.

(...) a literatura fin-de-siècle voltava-se para o interior, em direção ao ego narcisista, descompromissada, escapista, sensual e aristocraticamente refinada.

(...)

Como se mantinham ao contato dessas tendências, os brasileiros naturalmente as assimilavam e adaptavam; não se tratava apenas de copiá-las. As novas escolas encontraram eco entre os escritores que procuravam firmar suas reputações por meio da reelaboração particular das tendências em voga, e entre os membros da elite carioca, que, pelas razões conhecidas, vinculavam o prestígio à intimidade com a literatura parisiense. ${ }^{77}$

Entretanto, o resultado de tais fatores explicitou-se pela "fantasia de Civilização", ou seja, em uma literatura com fachada européia e civilizada, muito propícia para a elite carioca e de fato pouco comprometida com aspectos nacionais.

(...) a fantasia de Civilização, a identificação com os modos de vida e as concepções de uma cultura de elite, sobretudo franco-inglesa, foi adaptada às necessidades da elite carioca e bem interiorizada.

(...)

A literatura típica da belle époque, contudo, era estéril em termos nacionais. Seu modelo cosmopolita europeu combinava bem demais com a própria fachada da era.

Tal modelo, voltando-se para a vivência urbana, cosmopolita e narcisista da

\footnotetext{
76 NEEDEL, Jeffrey D. Belle Époque tropical: Sociedade e Cultura de Elite no Rio de Janeiro na Virada do Século. $2^{\circ}$ edição. São Paulo: Companhia das Letras, 2003. p.211.
}

77 NEEDEL, Jeffrey D. Op. Cit., 2003. p.232. 
aristocracia e da grande bourgeoisie, era uma literatura articulada com a experiência comum às elites urbanas no mundo europeizado como um todo.

(...) Assim, para determinadas minorias privilegiadas, a alta cultura do fin-de-siècle e a literatura belle époque adaptavam-se perfeitamente a seu modo de vida.

(...)

Desta maneira, a alta cultura e seus responsáveis mesclam-se à belle époque carioca, uma extensão da vida, do prazer e das perspectivas da elite." 78

A análise de Needel parece ir num sentido diverso daquelas que vimos até aqui. Para ele, o referencial imaginário europeu não serve de base para uma reinterpretação nacional ativa e nem para uma ação política. Esta divergência nos parece vir de opção metodológica diferente de Needel com relação aos outros atores que vimos até aqui. Needel seleciona como grupo social de análise a elite carioca, enquanto que os outros autores se debruçavam sobre as elites intelectuais.

Assim, diferente do que acontece com os intelectuais, a assimilação de ideias europeias para no Brasil, e sobretudo perante a elite do Rio de Janeiro, cria uma espécie de "fantasia de Civilização" paralisante. Esta é questão interessante de se observar pois parece revelar um aspecto mais amplo da sociedade brasileira do contexto, sobretudo se pensarmos na maneira como se dava a aceitação de certo "padrão de mentalidade".

De modo a compreender com maior profundidade a cena intelectual e o contexto em que ocorriam as questões até aqui levantadas é interessante analisar o estudo de José Murilo de Carvalho em seu Os Bestializados: O Rio de Janeiro e a República que não foi. Na obra o autor busca compreender a natureza das mudanças ocorridas na cidade do Rio de Janeiro nas primeiras décadas de República. ${ }^{79}$

Vale aqui destacar que a cidade do Rio de Janeiro era - além de capital da República o principal centro de concentração dos homens de letras do Brasil por concentrar os empregos que lhes davam o sustento material e por concentrar as mais importantes instituições culturais.

Vale aqui retomar a análise de Sevcenko em um ponto de destaque que não havíamos citado anteriormente: o fato de a história da Primeira República, inclusive do ponto de vista cultural, ser indissociável da história da cidade do Rio de Janeiro, em cujo crescimento, sobretudo a partir da Regeneração, trouxe novas e inimaginadas oportunidades para os

\footnotetext{
78 NEEDEL, Jeffrey D. Op. Cit., 2003. p.267-269.

${ }^{79}$ CARVALHO, José Murilo de. Os Bestializados: O Rio de Janeiro e a República que não foi. $3^{\text {a }}$ edição. São Paulo: Companhia das Letras , 2009.
} 
intelectuais, sobretudo no que diz respeito à produção de uma nova e "civilizada" imagem do Brasil.

(...) a proximidade da sede do governo federal, reformado e ampliado em suas múltiplas repartições, oferecia inúmeras oportunidades adicionais aos letrados, desde os simples empregos burocráticos até os cargos de representação, as comissões e as delegações diplomáticas. Igualmente importantes eram a tutela oferecida pelo Estado a organizações culturais e institutos superiores e o mecenato declarado do Ministério das Relações Exteriores aos grandes expoentes das letras. O Rio de Janeiro oferecia, pois, um campo ímpar de atuação para os intelectuais em um país pobre e quase totalmente analfabeto. Os cafés, confeitarias e livrarias da cidade populavam de múltiplos conventículos literários privados, compostos de confrarias vaidosas que se digladiavam continuamente pelos pasquins esporádicos da rua do Ouvidor. ${ }^{80}$

Ainda na visão de Carvalho se o início da República trazia para os intelectuais novas esperanças do ponto de vista da constituição da nação, não tardou a este sentimento se transformar em uma serie de decepções. Isto se deu por conta de diversos aspectos.

$\mathrm{O}$ autor inicia por pontuar alguns aspectos econômicos - como as consequências do fim da escravidão para o mercado de trabalho fluminense, o Encilhamento e as excessivas emissões monetárias que tiveram por consequência a especulação no mercado financeiro, o aumento da inflação e a desvalorização cambial, além das consequências econômicas imediatas da imigração

A abolição dos escravos lançou o restante da mão-de-obra escrava no mercado de trabalho livre e engrossou o contingente de subempregados e desempregados.

(...)

O novo regime pareceu uma autêntica república dos banqueiros, onde a lei era enriquecer a todo custo com dinheiro de especulação. (...) A seguir a inflação generalizada e a duplicação dos preços já em 1892. Ao mesmo tempo, começou a queda do câmbio, encarecendo ainda mais os produtos de importação, que na época abrangiam quase tudo.

(...)

O aumento no custo de vida era agravado pela imigração, que ampliava a oferta de mão-de-obra e acirrava a luta pelos escassos empregos disponíveis. ${ }^{81}$

São observados também aspectos políticos em transformação na então capital federal.

Com a proclamação da República ganha destaque a expectativa inicial de maior participação política de camadas excluídas na época imperial. Mas com ela vieram também novas tensões políticas entre republicanos e aqueles que defendiam a volta da Monarquia, além, vale evidenciar, do clima de permanente tensão promovido pelos jacobinos. ${ }^{82}$

\footnotetext{
80 SEVCENKO, Nicolau. Op. Cit., 2003. p.118.

81 CARVALHO, José Murilo de. Op. Cit., 2009. p.16, 20-21.

82 CARVALHO, José Murilo de. Op. Cit., 2009. p.22.
} 
A análise de Carvalho privilegia também os aspecto psicológico e as transformações que se deram no conjunto idéias e mentalidades: apesar de não ter se dado propriamente um despertar de novas idéias, houve maior liberdade para a circulação daquelas idéias presentes desde o período imperial.

A República não produziu correntes ideológicas próprias ou novas visões estéticas. Mas, por um momento, houve um abrir de janelas, por onde circulavam mais livremente idéias que antes se continham no recatado mundo imperial. ${ }^{83}$

Com todas estas transformações ocorridas na cidade do Rio de Janeiro, tornava-se politicamente explosivo concentrar a base de sustentação política do novo regime republicano na elite carioca e na população da cidade:

O problema central a ser resolvido pelo novo regime era a organização outro pacto de poder, que pudesse substituir o arranjo imperial com grau suficiente de estabilidade. (...) A natureza da tarefa que se impunha pode ser descrita como a necessidade de eliminar, ou pelo menos neutralizar, a influência da capital na política nacional. ${ }^{84}$

Uma solução dada para esta questão foi a Política dos Governadores, costurada pelo Presidente Campos Salles ao reunir as Oligarquias em um novo pacto político.

A maneira indireta de neutralizar a capital e as forças que nela agitavam era fortalecer os estados, pacificando e cooptando suas oligarquias. Era reunir as oligarquias em torno de um arranjo que garantisse seu domínio local e sua participação no poder nacional de acordo com o cacife político de cada uma. ${ }^{85}$

Dada a solução política para a estabilidade do regime, coube à cidade do Rio de Janeiro o papel de transformar-se em um cartão postal da República brasileira para o mundo. Dada a influência cultural francesa sob as elites de então - conforme observamos pela interpretação de Needel -, caracterizado sobretudo pela estética e mentalidade da belle époque, a cidade sofreu uma série de transformações com a intenção de se expressar e transmitir ao mundo a imagem de um Brasil civilizado.

Domesticada politicamente, reduzido seu peso político pela consolidação do sistema oligárquico de dominação, à cidade pôde ser dado o papel de cartão-postal da República. Entrou-se em cheio no espírito francês da belle époque, que teve seu auge na primeira década do século.

(...)

\footnotetext{
${ }^{83}$ CARVALHO, José Murilo de. Op. Cit., 2009 p.24.

84 CARVALHO, José Murilo de. Op. Cit., 2009 p.31.

85 CARVALHO, José Murilo de. Op. Cit., 2009 p.32.
} 
O brilho republicano expressou-se em formulas européias, especialmente parisienses. Mais que nunca, o mundo literários voltou-se para Paris, os poetas sonhavam viver em Paris e, sobretudo, morrer em Paris.

(...)

No Rio reformado circulava o mundo belle époque fascinado com a Europa, envergonhado do Brasil, em particular do Brasil pobre e do Brasil negro. Era o mundo do Barão do Rio Branco, ministro das Relações Exteriores do presidente que promoveu as Reformas. O mesmo Barão que na juventude tinha sido capoeira e que agora se esforçava em oferecer à visão do estrangeiro um Brasil branco, europeizado, civilizado. ${ }^{86}$

Esta questão de as elites policias brasileiras desejarem transmitir ao mundo, e sobretudo à Europa, a imagem de um Brasil civilizado nos é bastante cara e aparecerá reiteradas vezes em nosso trabalho. Vemos nela uma importante chave para entendermos o sentido de algumas posturas intelectuais de Oliveira Lima e de algumas políticas do Itamaraty de Rio Branco. Sobretudo vemos a questão como fundamental na compreensão do sentido dos discursos de divulgação do Brasil no exterior promovidos por Oliveira Lima, discussão que nos aprofundaremos no Capítulo 3. Por hora, basta que saibamos que ela se coloca no contexto, e em ações bastante simbólicas como a própria remodelação urbanística da capital federal, a cidade do Rio de Janeiro.

Outra questão que nos parece interessante na análise de Carvalho é a nova postura dos intelectuais em relação à política: se inicialmente houve entusiasmo com as novas perspectivas de participação advindas com a República em um segundo momento houve desapontamento a partir das perseguições a intelectuais empreendidas pelo governo de Floriano Peixoto.

A expectativa inicial, despertada pela República, de maior participação, foi sendo assim sistematicamente frustrada. Desapontaram-se os intelectuais com as perseguições do governo Floriano. ${ }^{87}$

$\mathrm{Na}$ interpretação de Vellozo, esta decepção com os rumos iniciais da República somente reforçavam "o espírito de missão que a intelectualidade do período assumia, creditando a si o papel de orientar o processo de reformas". Ou seja, Vellozo compartilha com Sevcenko e Alonso da interpretação do sentido politico da ação dos intelectuais, imbuídos de um sentimento de missão de construir a nação. Sentido este reforçado com as decepções republicanas.

\footnotetext{
${ }^{86}$ CARVALHO, José Murilo de. Op. Cit., 2009 p.39-41.

${ }^{87}$ CARVALHO, José Murilo de. Op. Cit., 2009 p.37.
} 
A visão de Vellozo difere, entretanto, da de Carvalho, para quem esta nova situação teve como consequência um rearranjo na forma como os intelectuais encarariam as suas perspectivas: "desistiram da política militante (diferente da postura da Geração de 1870) e se concentraram na literatura, aceitando postos decorativos na burocracia, especialmente no Itamaraty de Rio Branco", 88

Achamos importante complementar estas últimas observações de Carvalho com mais um trecho da análise de Sevcenko, desta vez no sentido de destacar a importância do recrutamento de intelectuais para os postos do Itamaraty. Lotar os intelectuais em postos diplomáticos era estratégico no sentido de busca de prestígio por parte do Brasil, sobretudo perante as nações européias:

Urdidura propícia, da qual os autores emergiram como um atavio necessário, à medida que contribuiriam para consolidar a imagem austera de uma sociedade ilustre e elevada, merecedora da atenção e do crédito europeu incondicional. Imagem que não escapou à visão arguta de Rio Branco, que procurou lotar as dependências do Itamaraty, e mesmo de setores paralelos da administração, de intelectuais respeitáveis, ou de quem afetasse uma tal moldura. ${ }^{89}$

Já havíamos observado este movimento de concentração dos esforços de construção da nacionalidade na literatura quando analisamos a interpretação de Candido. A análise de Carvalho e Sevecenko nos trazem como elemento novo o descontentamento por parte dos intelectuais com a República e - assim como também já havíamos destacado na interpretação de Miceli sobre os anatolianos como "intelectuais assalariados" - o novo posicionamento profissional dos intelectuais na burocracia estatal, em destaque o Itamaraty e a figura central exercida pelo Barão do Rio Branco ao recrutar deliberadamente intelectuais para o serviço diplomático

Reafirmamos aqui a nossa visão da importância de vermos o Oliveira Lima como um desses intelectuais, militantes da questão da construção da nacionalidade via literatura embora em seu caso seja mais via historiografia e critica literária - e ligado profissionalmente à burocracia enquanto diplomata.

Vale ressaltar, porém, que Oliveira Lima, então republicano convicto, mesmo com as dificuldades dos anos iniciais da República não desistiu da política militante e fez de sua "literatura" e da diplomacia palcos privilegiados de sua ação. Nos parece que é neste sentido

${ }^{88}$ CARVALHO, José Murilo de. Op. Cit., 2009 p.37.

${ }^{89}$ SEVCENKO, Nicolau. Op. Cit., 2003. p.118. 
que Vellozo coloca o reforço da ação política com as decepções dos anos iniciais republicanos. Assim, Oliveira Lima talvez seja um caso que vá num sentido diferente daquele colocado por Carvalho: não desistiu da política militante, se dedicou à historiografia e à crítica literária e não via como decorativo sua colocação na burocracia, principalmente no Itamaraty de Rio Branco, onde defendeu posições de maneira bastante veemente no sentido daquilo que acreditava ser a política externa mais adequada. Tudo isto tendo como pano de fundo a questão da construção da nacionalidade. 


\title{
Capítulo 2 - Rede de Sociabilidade Intelectual e posicionamentos de Oliveira Lima
}

Vamos neste segundo capítulo continuar avançando na contextualização. Há aqui um elemento - ainda não explicitamente mencionado - essencial para o melhor entendimento das questões postas neste trabalho: as redes de sociabilidade intelectual. Tão essencial e importante que decidimos abri um novo capitulo dedicado exclusivamente a ele.

O leitor atendo deve ter notado que diversas vezes foi mencionada a questão da baixa autonomia entre os campos intelectual e politico. Notou também que nos reportamos a Oliveira Lima enquanto homem de letras e diplomata, envolvido simultaneamente nas questões da literatura, da historiografia e da política externa. Pois bem, isto se dá muito por conta de sua rede de sociabilidade intelectual, ou seja, pela maneira como se configuram as relações entre os intelectuais naquele contexto. Estamos aqui falando sim, leitor atento, das redes de sociabilidade intelectual que apresentamos na Introdução deste trabalho enquanto metodologia proposta por Sirinelli.

Assim, este segundo capítulo tem como objetivo analisar a rede de sociabilidade intelectual na qual Oliveira Lima circulava, de modo a compreender suas dinâmicas e pautas, seus atores e projetos. Paralelamente iremos apresentar os posicionamentos de Lima perante as questões em pauta.

Há uma percepção interessante feita por Angela de Castro Gomes em seu História e Historiadores sobre os historiadores - ou como a autora que, os homens de letras - dos anos iniciais da República a partir da perspectiva das redes de sociabilidade intelectual.

\begin{abstract}
A noção de sociabilidade moderna, que vem igualmente sendo discutida, em particular por uma literatura dedicada à "história dos intelectuais", acoplada à ideia de geração, permite um interessante tratamento da amostra de historiadores. (...) Os lugares de sociabilidade de uma geração - escolas, associações intelectuais, revistas, salões, etc. - podem ser indicadores valiosos para a analise de movimentos de produção e circulação de ideias. Quais são estes lugares? Como se formam e com base em que elementos e projetos se estruturam? Todas essas questões, quando esclarecidas, podem elucidar aspectos da constituição de uma formulação intelectual, de sua vitalidade e continuidade através do tempo. ${ }^{90}$
\end{abstract}

Responder a estes questionamentos colocados por Gomes é exatamente o que vamos procurar fazer ao longo deste capitulo.

${ }^{90}$ GOMES, Angela de Castro. História e Historiadores. Rio de Janeiro: Editora FGV, 2013. p.41-42. 


\section{1 - Rede, pautas e instituições}

Vale, logo de início, pontuar a compreensão de que, naquele momento específico, a circulação do conhecimento nas redes de sociabilidade intelectuais tinha como pauta central a questão da construção da nacionalidade. Mais do que isso, tal pauta central reverberava nas mais diversas instituições políticas ou produtoras de conhecimento, que, em suas buscas por autonomia, encaravam tal pauta a partir de suas especificidades.

Note-se que colocamos aqui um conceito novo: instituições políticas ou produtoras de conhecimento. Estamos falando aqui especificamente de três delas, nas quais Oliveira Lima circulava: Itamaraty, Instituto Histórico e Geográfico Brasileiro (IHGB) e Academia Brasileira de Letras (ABL).

Vale ainda ressaltar que o início do século XX no Brasil marcou um processo de transição nas instituições políticas e produtoras de conhecimento. Tal processo enfraquecia a centralização da produção do conhecimento em instituições governamentais nacionais - como o IHGB e, de certa forma, o Itamaraty - para uma maior diversificação e introdução de novas pautas e visões a partir dos Institutos Históricos e Geográficos estaduais, dos literatos da ABL e da imprensa em formação. Este processo tem um paralelo com a maior autonomia dada aos estados da federação brasileira e às associações de classes a partir da Constituição Republicana de $1891 .{ }^{91}$

Relembremos que Oliveira Lima era membro ao mesmo tempo de diversas instituições, ao redor das quais se formou sua rede de sociabilidade intelectual: além dos já mencionados Itamaraty, IHGB e ABL, circulava também pelos Instituto Arqueológico, Histórico e Geográfico de Pernambuco (IAHGP) e Instituto Histórico e Geográfico de São Paulo (IHGSP). Estava portanto, inserido neste processo de transição nas instituições políticas e produtoras de conhecimento do início do século XX.

Talvez justamente por se tratar de um momento de transição observa-se um fenômeno no qual um mesmo indivíduo pertence ao mesmo tempo à diversas instituições em disputa intelectual pela "idéia de Brasil". Assim, é interessante notar que um mesmo indivíduo se

\footnotetext{
91 IUMATTI, Paulo Teixeira; VELLOZO, Julio César de Oliveira. Conhecimento, política e instituições no Brasil (1889-1934). Revue pluridisciplinaire du monde Lusophone, n², Université de Toulouse Le Mitral, 2013.
} 
coloca em diversas disputas e tem diferentes (ou iguais) posicionamentos por estar jogando ao mesmo tempo em diversos "tabuleiros".

Este fenômeno ocorre com diversos intelectuais, de modo que houvessem disputas e pautas diferente com os mesmos indivíduos em diferentes instituições. Joaquim Nabuco era colega de Oliveira Lima no Itamaraty e na ABL e o Barão do Rio Branco colega de Lima no Itamaraty e IHGB. Assim, havia ocasiões, não raras, que estas pautas e disputas se misturavam, como é o caso das críticas que Oliveira Lima tece à maneira como Rio Branco administra o Itamaraty em plena sessão do IHGB, por exemplo. Este episódio é pode ser visto enquanto uma resposta do diplomata ao Barão por conta de uma remoção para um posto indesejado: Lima, no Peru, considerado por Oliveira Lima como um desprestígio, um posto inferior em uma "nação bárbara". Voltaremos mais adiante às disputas e polêmicas entre Oliveira Lima e seus dois principais interlocutores: Barão do Rio Branco e Joaquim Nabuco.

Deve-se ter estas especificidades em mente quando do esforço de entender as disputas e pautas nas diferentes instituições, nos atendo, mas tentando superar, as dificuldades que se apresentam aos estudos das redes de sociabilidade intelectual do Brasil do início do século XX.

\subsection{1 - IHGB}

Analisaremos agora o Instituto Histórico e Geográfico Brasileiro, IHGB, enquanto instituição produtora de conhecimento dentro da lógica da rede de sociabilidade intelectual na qual Oliveira Lima circulava.

Em seu artigo "Nação e Civilização nos Trópicos",92, Manoel Luis Salgado Guimarães nos apresenta uma interessante visão sobre algumas questões que rondavam o IHGB. O Instituto fora fundado em 1838, ainda no Império, nos moldes das academias ilustradas européias por um grupo da elite intelectual e política de então. Com a inauguração da sede do Instituto no Paço Imperial em 1849, aprofundaram-se a relações já colocadas desde seu início com o Estado Imperial. O aprofundamento se deu, diga-se, com o próprio Imperador D. Pedro II, que a partir deste momento passou a se envolver cada vez mais com as questões do Instituto.

\footnotetext{
92 GUIMARÃES, Manuel Luis Salgado. Nação e Civilização nos Trópicos: o Instituto Histórico e Geográfico
} Brasileiro e o Projeto de uma História Nacional. In: Estudos Históricos. Rio de Janeiro, n 1. 1988. p.5-27. 
O objetivo do IHGB era "pensar a história" nacional de modo que esta se articulasse com um quadro mais amplo da já identificada questão nacional. Além disso, devemos ter em mente que, à época, um projeto de uma "História Nacional" guardava vinculações com o próprio processo de consolidação do Estado Nacional.

(...) Uma vez implantado o Estado Nacional, impunha-se como tarefa o delineamento de um perfil para a "Nação brasileira", capaz de lhe garantir uma identidade própria no conjunto mais amplo das "Nações", de acordo com os novos princípios organizadores da vida social do século XIX.

$(\ldots)$

E, portanto, à tarefa de pensar o Brasil segundo os postulados próprios de uma história comprometida com o desvendamento do processo de gênese da Nação que se entregam os letrados reunidos em torno do IHGB. $^{93}$

O projeto estava de uma certa forma ancorado em um programa programático baseado no texto "Como se deve escrever a História do Brasil"94 de von Martius, publicado em 1845 no principal veiculo de circulação de ideias do Instituto, a Revista do IHGB. Reproduziremos, neste sentido, mais algumas reflexões de Guimarães sobre a questão. o trecho, apesar de longo, é esclarecedor.

O texto do alemão von Martius, cientista ocupado das coisas brasileiras, já fora publicado na Revista em 1845 e se revestia de um caráter pragmático, como aliás o próprio título sugere. No artigo, von Martius define as linhas mestras de um projeto historiográfico capaz de garantir uma identidade - especificidade à Nação em processo de construção. Essa identidade estaria assegurada, no seu entender, se o historiador fosse capaz de mostrar a missão reservada ao Brasil enquanto Nação: realizar a idéia da mescla das três raças, lançando os alicerces para a construção do nosso mito da democracia racial.

(...)

O texto de von Martius propõe uma forma de tratar cada um dos três grupos étnicos formadores, a seu ver, da nacionalidade brasileira, e inicia valorizando os estudos relativos aos indígenas, com a perspectiva de integrar a história nacional os conhecimentos por eles veiculados. Certamente a atuação do elemento branco, através de seu papel civilizador, será particularmente sublinhada, resgatando especialmente a importância dos bandeirantes e das ordens religiosas nesta tarefa desbravadora e civilizatória. (...). O negro obtém pouca atenção de von Martius, reflexo de uma tendência que se solidificaria neste modelo de produção da história nacional: a visão do elemento negro como fator de impedimento ao processo de civilização. ${ }^{95}$

Não cabe a nós, aqui neste trabalho, discutir em profundidade as implicações historiográficas dos tratamentos dados por von Martius a cada um dos grupos étnicos. Colocado de outro modo: apesar de reconhecermos a importância, não exploraremos a

\footnotetext{
93 GUIMARÃES, Manuel Luis Salgado. Op. Cit., 1988. p.6.

94 MARTIUS, Karl Friedrich Philipp von. Como se deve escrever a História do Brasil. In: Revista do IHGB. Rio de Janeiro, 6(24). Jan. 1845. p.381-401.
}

95 GUIMARÃES, Manuel Luis Salgado. Op. Cit., 1988. p.16. 
questão indígena e a questão do negro dentro das discussões do IHGB. Cabe, entretanto, salientar um certa continuidade da perspectiva de von Martius com os escritos de Adolfo Varnhagen, sobretudo no que se refere ao papel civilizador do elemento branco.

Se a von Marthius coube apresentar um programa programático para o IHGB, foi em torno dos escritos de Varnhagen que se definiu com maior precisão a visão que a historiografia do IHGB tinha sobre a constituição da Nação Brasileira.

\footnotetext{
No momento que defini-se o Brasil, defini-se também o "outro" em relação a esse Brasil. Num processo muito próprio ao caso brasileiro, a construção da idéia de Nação não se assenta sobre uma oposição à antiga metrópole portuguesa: muito ao contrário, a nova Nação brasileira se reconhece enquanto continuadora de uma certa tarefa civilizadora iniciada pela colonização portuguesa. Nação, Estado e Coroa aparecem enquanto uma unidade no interior da discussão historiográfica relativa ao problema nacional. (...)

É Francisco Adolfo Varnhagen que, em carta ao Imperador Dom Pedro II, explicitaria os fundamentos definidores da identidade nacional brasileira enquanto herança da colonização europeia. (...).

$(\ldots)$

A leitura da história empreendida pelo IHGB está, assim, marcada por um duplo projeto: dar conta de uma gênese da Nação brasileira, inserindo-a contudo numa tradição de civilização e progresso, idéias tão caras ao Iluminismo. A Nação, cujo retratado o Instituto se propõe a traçar, deve, portanto, surgir como o desdobramento nos trópicos, de uma civilização branca e européia. (... $)^{96}$
}

É assim, a partir da idéia de continuidade da Nação brasileira com relação à portuguesa, sobretudo em sua tarefa civilizadora, que Varnhagen coloca o Brasil enquanto uma espécie de Civilização nos Trópicos.

Oliveira Lima ingressou no IHGB em 1895 e em sua produção historiográfica compartilha em certa medida com Varnhagen desta idéia de continuidade do Brasil com relação à Portugal, embora a veja a partir de prisma distinto. Na visão de Vellozo, para Lima a continuidade não está tanto na tarefa civilizadora, e sim na transição pactuada e na ausência de rupturas em momentos fundamentais para a constituição da nacionalidade, como a vinda da corte de Dom João VI ao Brasil, a forma como se deu o processo da Independência brasileira e o reinado de Dom Pedro II. Em outras palavras, Oliveira Lima via a continuidade com relação à Portugal no papel dos Bragança na constituição da Nação brasileira. ${ }^{97}$

Esta interpretação de Oliveira Lima, mesmo que vista sob óptica diferente da de Varnhagen com relação à questão da continuidade, leva a uma idéia semelhante de Brasil

\footnotetext{
${ }^{96}$ GUIMARÃES, Manuel Luis Salgado. Op. Cit., 1988. p.6-8

97 VELLOZO, Júlio Cesar de Oliveira. Op. Cit., 2012
} 
enquanto Civilização nos Trópicos. Isto se dá, para Lima, pelo fato de os Bragança terem garantido a continuidade da tradição lusitana, portanto européia, civilizada, no Brasil.

Vale aqui ressaltar que a idéia de Oliveira Lima, de que o Brasil é herdeiro das tradições da Civilização européia, é em certo grau compartilhada pelo Barão do Rio Branco. Como mencionamos anteriormente - e veremos em maior profundidade mais adiante - a relacionamento entre Oliveira Lima e o Barão não era dos mais amistosos. Daí a importância em ressaltarmos essa aproximação em termos de "idéia de Brasil".

Ainda mais em questões historiográficas como são as tratadas no IHGB, instituição produtora de conhecimento na qual Oliveira Lima participou mais ativamente entre 1906 e 1908, justamente os anos iniciais do Barão do Rio Branco na presidência do Instituto. Vale ainda lembrar, que o Barão era também neste período o Chanceler do Itamaraty, portanto chefe de Oliveira Lima no serviço diplomático, questão a que nos dedicaremos em outro momento neste capítulo.

Mais um interlocutor de Lima que merece destaque dentro da análise sobre o IHGB é Max Fleiuss. A documentação sobre Fleiuss nos pareceu bastante dispersa e fragmentada, mas pelo que pudemos observar, entendemos que desempenhava um papel central dentro do funcionamento do IHGB. Fleiuss nos pareceu uma espécie de secretário geral, centralizador das informações e diálogos, produções e circulação do conhecimento dentro da instituição, quase que a personificação do IHGB.

Assim, os conflitos entre Oliveira Lima e Rio Branco dentro das questões do IHGB pareciam passar pela mediação de Fleuiss, de modo que as desavenças ficassem restritas às questões dos corredores do Itamaraty e as aproximações das concepções historiográficas ganhassem relevo.

Voltando às comparações com Varnhagen, devemos também considerar que a produção historiográfica de Oliveira Lima se deu em momento diverso: não mais o século XIX sob o Império, e sim o inicio do século XX sob a República. Esta mudança de panorama trouxe também um novo paradigma para a produção e reflexão do conhecimento historiográfico.

Já mencionamos anteriormente a concepção de Iumatti e Vellozo de que o regime republicano, e sobretudo sua Constituição de 1891, proporcionou maior autonomia aos estados da federação brasileira e às associações de classes. Mencionamos também que na 
esteia deste processo veio uma maior autonomia por parte de instituições produtoras de conhecimento regionais, como o IHGSP e o IAHGP, com relação às instituições centralizadoras das discussões da questão da nacionalidade vindas desde o Império, como o IHGB. $^{98}$

Este novo paradigma resultou em elementos novos do ponto de vista da produção e das concepções sobre o conhecimento, sobretudo historiográfico.

\begin{abstract}
Em primeiro lugar, destacamos na produção desses intelectuais a consciência de que o conhecimento de alguma forma lida não só com simplificações, mas principalmente com complexidades. (...) O modo como Oliveira Lima trabalha as mediações entre economia, sociedade, política, cultura e natureza em Dom João VI no Brasil são indicativos desse apanágio de nova sensibilidade.

(...)

O segundo elemento deste novo paradigma do conhecimento está intrinsicamente ligado a esse reconhecimento do conjunto de complexidades com que lidava, em diversos níveis, o conhecimento: trata-se da consciência de que o conhecimento tem caráter limitado e, necessariamente, especializado. ${ }^{99}$
\end{abstract}

Sabemos que Oliveira Lima circulava por entre estas instituições e esteve em meio às reflexões que envolviam essas novas concepções sobre o conhecimento historiográfico. Vemos o reflexo deste novo paradigma em sua produção mais complexa e especializada.

Vale também citarmos que, segundo as observações de Vellozo, houve em dado momento uma inflexão na maneira como Oliveira Lima concebia a historiografia do Brasil. Mais precisamente durante sua estada no Japão, país no qual Lima serviu ao Itamaraty enquanto Encarregado de Negócios, entre anos de 1901 e 1903. 100

Até aquele momento, Lima vinha observando a "evolução das Nações" e as possibilidades e perspectivas de modernização do Brasil - questão central à época dentro das discussões sobre a questão da nacionalidade brasileira - sob um prisma que evidenciava a superioridade de determinadas culturas/raças.

Foi assim em suas observações sobre os Estados Unidos e sua comparação com o Brasil, conforme pontuamos no capítulo anterior. A superioridade e as perspectivas positivas de progresso e modernização dos vizinhos norte-americanos advinham sobretudo de questões

\footnotetext{
${ }^{98}$ IUMATTI, Paulo Teixeira; VELLOZO, Julio César de Oliveira. Op. Cit., 2013.

${ }^{99}$ IUMATTI, Paulo Teixeira; VELLOZO, Julio César de Oliveira. Op. Cit., 2013. p.10.

100 VELLOZO, Júlio Cesar de Oliveira. Op. Cit., 2012
} 
culturais e raciais herdadas da tradição anglo-saxã. Era um esquema de interpretação um tanto centrada em determinismos raciais o colocado por Lima em seu Nos Estados Unidos.

Em sua experiência no Japão, Oliveira Lima teve contato com um novo paradigma civilizacional que marcou e transformou a maneira como concebia a "evolução das Nações" e suas possibilidades de modernização.

(...) A pedra de toque da experiência japonesa de Lima foi seu balanço do processo de modernização vivido pelo Japão e que ele pôde acompanhar como observador privilegiado. Dito de outro modo, um Lima extasiado diante do Japão, descobriu que a acelerada modernização à japonesa era marcada por um mecanismo de apropriação do novo que não necessitava anular o velho; pelo contrário, se apoiava nas antigas tradições para melhor se aclimatar. Este caminho se transformaria na via defendida por Oliveira Lima para a modernização brasileira. ${ }^{101}$

Vellozo prossegue em sua observação sobre o impacto da experiência japonesa nas concepções de Lima justamente por comparar suas obra Nos Estados Unidos e No Japão, relatos das experiências de Lima quando de sua estada naqueles países.

Se em Nos Estados Unidos, Oliveira Lima considera que só há um caminho para o progresso, todo ele baseado na cultura de origem anglo-saxã desenvolvida nos EUA, onde os interesses particulares, o individualismo, o culto à riqueza, são condições sine qua non para o avanço rumo à modernidade, em No Japão o autor descobre que o caminho para o futuro está franqueado para outras culturas. Passaram a existir as condições para que o autor abandone progressivamente a prescrição de um americanismo radical e passe a defender que o Brasil construa um caminho próprio para a modernização que se baseie em suas tradições. ${ }^{102}$

Esta mudança de paradigma nos ajuda a entender a perspectiva de Oliveira Lima sobre a importância das tradições portuguesas na constituição da nacionalidade brasileira. Daí vem o posicionamento que conhecemos de Lima diante das questões historiográficas colocadas à seu tempo nas questões sobre o Brasil.

Como conclusão quase inevitável, o autor chega à formulação que o acompanharia daí por diante: o Brasil devia valorizar seu passado e suas tradições ibéricas e, ao contrário do que pensara até então e do que sustentavam a maioria dos pensadores do início da República, o passado português não era um opróbrio, mas um triunfo. ${ }^{103}$

Mas Oliveira Lima não somente produziu historiografia - a destacar seus Dom João VI no Brasil - como também refletiu sobre as questões postas à produção do conhecimento

\footnotetext{
${ }^{101}$ VELLOZO, Júlio Cesar de Oliveira. Op. Cit., 2012. p.113.

102 VELLOZO, Júlio Cesar de Oliveira. Op. Cit., 2012.p.118.

${ }^{103}$ VELLOZO, Júlio Cesar de Oliveira. Op. Cit., 2012. 119.
} 
historiográfico sob este novo paradigma vindo junta à mudanças trazidas pelo regime republicano.

\begin{abstract}
No contexto de especialização e "dispersão da mataria histórica", Oliveira Lima argumentaria que era preciso conciliar ciência e arte, história e literatura, ciência e "crítica", ciência e interpretação, a fim de "comunicar vibração às turbas desaparecidas", de reconstruir, com um aglomerado de pormenores, um caráter humano, ou dele deduzir uma "lei de evolução". Esta elaboração demandava mais do que uma faculdade psicológica aguçada por subida e moderna preparação científica, a internet obra crítica com que escritores como Michelet e Maine haviam contado a ampará-los. ${ }^{104}$
\end{abstract}

Vemos por este trecho uma interessante constatação sobre a visão de Lima sobre o conhecimento histórico. Nos chama a atenção em seu pensamento a presença ao mesmo de elementos modernos, do novo paradigma, como a questão da especialização e da complexidade e a permanência de uma concepção vinda desde paradigmas anteriores, a destacar a idéia de que caberia à História detectar e reconstruir uma certa "lei da evolução".

Por fim, entendemos que estes seus esforços de produção e reflexão sobre o conhecimento historiográfico atingiu uma recepção relevante por parte de seus interlocutores historiadores. Podemos, assim, concluir que Oliveira Lima ocupava um papel de certa centralidade perante seus pares do IHGB e dos institutos regionais., de modo a alcançar um grau de prestígio considerável enquanto historiador, ou melhor, enquanto Homem de Letras.

\title{
2.1.2 - ABL
}

Partiremos agora para a análise de outra instituição produtora de conhecimento na qual Oliveira Lima circulava e estabelecia diálogos dentro de sua rede de sociabilidade intelectual: a Academia Brasileira de Letras. A analisaremos atentando para sua dinâmica, pautas e questões, assim como para o posicionamento de Oliveira Lima diante destes fatores.

Vale, logo de início, destacar que a ABL é uma instituição literária criada a partir dos moldes das Academias francesas e cuja aspiração era o promoção e proteção dos literatos e da literatura nacional.

Seus membros, muitos de famílias importantes, eram ilustres nas letras. Os quarenta "imortais" tiraram seu número da instituição de Richelieu e adaptaram o mesmo ritual das cadeiras que passavam de ocupante para ocupante, batizando-as com o nome dos "fundadores" e fabricando, deste modo, a linhagem literária das cadeiras.

${ }^{104}$ IUMATTI, Paulo Teixeira; VELLOZO, Julio César de Oliveira. Op. Cit., 2013. p.12. 
Também adotaram o costume francês de receber e saudar os novos membros com discursos celebrando sucessores e predecessores. A praxe acadêmica sublinhava o que os discursos inaugurais explicitavam - tratava-se de uma organização à la française, criada para fortalecer a tradição literária, preservar a pureza da língua e promover, na nação recém-nascida, o respeito pelos feitos literários e o encorajamento de uma literatura verdadeiramente nacional. ${ }^{105}$

Outra questão cara à ABL é a sua postura dita apolítica, de certa maneira, diferente do ativismo político que marcou a geração de 1870 .

\begin{abstract}
O que falta é o comprometimento com a sociedade em geral que havia sido marca da geração de setenta. Os literatos não mais consideravam ter um papel na regeneração política. Eles haviam se retirado para o reduto romântico. Sua missão voltara a ser, antes de tudo, literária, no sentido estrito. Sua tarefa, como a das primeiras gerações literárias, era definir a alma nacional por intermédio de sua vigorosa expressão literária. (...)

O distanciamento em relação ao ativismo politico e o desejo de reconhecimento oficial enquanto árbitros e produtores de cultura implicavam a aceitação dos valores dominantes na sociedade, ou seja, dos valores da elite. ${ }^{106}$
\end{abstract}

Este distanciamento em relação ao ativismo politico precisa, entretanto ser relatividade. Uma vez que - como veremos - uma das principais pautas da ABL é justamente a formação de uma literatura nacional, suas disputas estão de certo modo envolvidas na questão da constituição da nacionalidade. Refletir e defender posições nas pautas colocadas pela ABL não deixa de ser, assim, uma maneira de atuação política via literatura.

Oliveira Lima foi colaborador da Revista Brasileira de José Veríssimo, núcleo inicial em torno do qual se constituiu a ABL. Posteriormente, veio a ser escolhido, aos 29 anos - e em preterência, entre outros, ao Barão do Rio Branco, por exemplo - um dos membros fundadores da $\mathrm{ABL}$. Assim é interessante explorar de maneira mais aprofundada as questões da Academia, uma vez que a instituição aparece enquanto uma dos principais palcos de atuação de Lima.

Nesse sentido, exploraremos inicialmente o prefácio entitulado "As duas Repúblicas" escrito por José Murilo de Carvalho à 3a edição do volume de correspondências entre Machado de Assis e Joaquim Nabuco, organizada por Graça Aranha. Trata-se, na realidade, de apresentar a Academia Brasileira de Letras em seus momentos iniciais, além de analisar as questões levantadas no período de sua formação. É deste contexto boa parte das cartas

\footnotetext{
105 NEEDEL, Jeffrey D. Op. Cit., 2003. p.226.

106 NEEDEL, Jeffrey D. Op. Cit., 2003. p.227-228.
} 
trocadas ente Machado e Nabuco, por onde discutiam sobretudo sobre as dificuldades para o estabelecimento da instituição. ${ }^{107}$

Quanto ao que disseram, a Academia Brasileira de Letras foi sem dúvida o assunto predominante. A partir de 1899, das 47 cartas trocadas entre eles, 37 falavam dela. Nabuco pedia notícias, discutia eleições, mandava votos, expunha suas idéias sobre a natureza da instituição. Manifestava constante preocupação com o destino da Casa. (...) Machado também parecia ter dúvidas quanto à saúde da instituição. (...) A preocupação com o destino da Academia indica as dificuldades que enfrentavam para se afirmar como instituição no cenário cultural do país. ${ }^{108}$

Dentre as dificuldades, ganham destaque a falta de recursos financeiros, mal-estares causados por algumas eleições para os membros da Academia, a recusa por parte de alguns intelectuais importantes como Capistrano de Abreu e Quintino Bacaiúva em participar da instituição e, por fim, a oposição explícita à Academia por parte de alguns excluídos como Lima Barreto e Cruz e Sousa. ${ }^{109}$

Era também objeto de conversa entre Machado e Nabuco o modelo a ser adotado para a Academia: entre uma instituição mais aberta à intelectualidade brasileira como um todo, posição defendida por Nabuco, e uma instituição mais restrita aos literatos, posição defendida por Machado.

\begin{abstract}
Sabe-se que houve hesitação inicial entre se criar uma Academia Brasileira à maneira da Académie Française, aberta a não literatos, e uma Academia Brasileira de Letras, destinada exclusivamente a literatos. (...) Nabuco, homem público por excelência, favorecia o modelo da Académie Française.

(...)

Queria uma instituição nacional, cujos sócios seriam recrutados entre os grandes nomes da Igreja, das artes, do jornalismo, da Marinha, do Exército. (...) Machado não discordava de Nabuco, mas, literato por excelência, não parecia entusiasta da idéia. $\mathrm{Na}$ prática, enquanto ele viveu, foram admitidas algumas notabilidades estranhas ao mundo literário, como o Barão do Rio Branco, Jaceguai e o médico Grancisco de Castro. ${ }^{110}$
\end{abstract}

Carvalho destaca também as dificuldades enfrentadas para o estabelecimento da $\mathrm{ABL}$ em comparação com o estabelecimento do IHGB, fundado em um contexto menos complexo e com o apoio oficial do Império na pessoa do Imperador Pedro II.

Pode-se dizer que a batalha da Academia para afirmar-se como instituição cultural foi mais árdua do que for a a do IHGB. Este surgira 60 anos antes, quando o mundo intelectual era muito mais reduzido e homogêneo, e contou com o patrocínio de

107 CARVALHO, José Murilo de. As duas repúblicas. In: Machado de Assis \& Joaquim Nabuco: Correspondência. $3^{\text {a }}$ edição. Rio de Janeiro: Topbooks, 2003.

108 CARVALHO, José Murilo de. Op. Cit., 2003. p.11.

${ }^{109}$ CARVALHO, José Murilo de. Op. Cit., 2003. p.12-13.

110 CARVALHO, José Murilo de. Op. Cit., 2003. p.13-14. 
Dom Pedro II. (...) A ABL teve que conciliar muito mais, teve de agasalhar um grupo mais diversificado do ponto de vista político, literário e geracional, teve de buscar um espaço de convivência dentro da profunda cisão causada pela proclamação do novo regime. ${ }^{111}$

O contexto político turbulento dos anos iniciais da República e as perseguições por parte do governo Floriano aos intelectuais marcou uma das características mais relevantes da ABL: lá não se falava de política. Tal característica parece vir desde as correspondências entre Machado e Nabuco, onde não se conversava do assunto. "Parece ter havido entre Machado e Nabuco um pacto não escrito: não se fala de política". 112

Este contexto de turbulência política parece ter inclusive um dos elementos que incentivaram os intelectuais em seu esforço para a criação da ABL: "Fatigados da política, (...), os literatos decidiram criar para si mesmos uma república sem política, a república das letras". ${ }^{113}$

Os momentos iniciais de formulação das bases de relacionamento daquilo que viria a ser a Academia ocorreram em torno de reuniões lideradas por José Veríssimo na sede de sua Revista Brasileira, onde monarquistas e republicanos conversavam de diversos temas ligados às letras, à arte e à filosofia, mas que tinha como regra básica não se discutir política.

O primeiro ensaio da nova comunidade, como sabe-se, deveu-se à Revista Brasileira, recriada pelo republicano José Veríssimo em 1895. (...) Lá, Rodrigo Octavio tornou-se amigo do monarquista Nabuco. Lá, começaram a conviver o mesmo Nabuco e o apolítico Machado.

(...) Não se falou de política, (...). Não se falou também de mulheres, só de letras, artes, poesia, filosofia. Era essa a base da convivência pacífica que deixou boas lembranças.

Da experiência da Revista surgiu a Academia em 1897. (...) A regra de evitar o debate político, estabelecido na Revista Brasileira, persistiu na Academia. ${ }^{114}$

Outra característica importante da Academia em seus momentos iniciais era a intenção de que ela funcionasse como uma espécie de "torre de marfim". "Machado(...) no discurso de encerramento dos trabalhos de 1897: "Homens daqui podem escrever páginas de história, mas a história faz-se lá fora". A Academia deveria ser uma torre de marfim. " 115

\footnotetext{
111 CARVALHO, José Murilo de. Op. Cit., 2003. p.14.

${ }^{112}$ CARVALHO, José Murilo de. Op. Cit., 2003. p.14.

${ }^{113}$ CARVALHO, José Murilo de. Op. Cit., 2003. p.16.

114 CARVALHO, José Murilo de. Op. Cit., 2003. p.16-17.

${ }^{115}$ CARVALHO, José Murilo de. Op. Cit., 2003. p.17.
} 
Para tal, a ausência do debate político e a criação de hábitos de cortesia e civilidade entre os sócios eram fundamentais, vistos como bases da sociabilidade para a formação de uma esfera autônoma de atividade intelectual. Todo este esforço tinha, na realidade, como objetivo primordial a "profissionalização dos literatos".

(...) tratava-se, como observou José Veríssimo nos Estudo de literatura brasileira, 6a série, de criar entre os escritores hábitos de cortesia e civilidade, escassos, Segundo ele, na vida literária do país. O desenvolvimento de tais hábitos era essencial para a formação de uma esfera autônoma de atividade, regulada por valores próprios e regras especiais de comportamento. Era essencial para atingir um objetivo central de todos: a profissionalização dos literatos. ${ }^{116}$

Por fim, retomando a questão sobre o modelo a ser adotado pela Academia, Carvalho defende que acabou por prevalecer o modelo defendido por Nabuco, da abertura para os homens de letras, ou seja, os intelectuais como um todo. Assim, a Academia representaria uma espécie de "intelectual coletivo da outra República", sendo esta sua "característica mais nobre". 117

Partimos agora para uma análise específica da postura de Oliveira Lima diante das questões em pauta na ABL. Ganha destaque o ensaio Dois letrados e o Brasil Nação ${ }^{118}$, de Antonio Arnoni Prado, no qual o autor traça comparações entre Oliveira Lima e Sérgio Buarque de Hollanda a partir de suas trajetórias e idéias. Sem deméritos ao autor de Raízes do Brasil, cabe aqui, por conta do foco do presente trabalho, apenas pontuarmos as análises de Prado a respeito de Oliveira Lima.

Oliveira Lima inicia sua trajetória intelectual, ainda estudante de Letras na Universidade de Lisboa, num contexto de deslumbramento com a geração de 1870, sobretudo nas figura de Teófilo Braga, e suas idéias nacionalistas ligadas ao "despertar da pátria lusitana". ${ }^{119}$

Esta ligação com a Europa marcou toda sua trajetória intelectual, seja em sua concepção historiográfica de "ressurreição artisticamente construída" sob influência de

\footnotetext{
${ }^{116}$ CARVALHO, José Murilo de. Op. Cit., 2003. p.17.

117 CARVALHO, José Murilo de. Op. Cit., 2003. p.18.

118 PRADO, Antônio Arnoni. Op.Cit. 2010.

119 PRADO, Antônio Arnoni. Op.Cit. 2010.
} 
Oliveira Martins, intelectual da mesma geração de 1870 lusitana, seja na influência do ideário da belle époque e a vivência de seu cosmopolitismo em salões, espetáculos e conferências. ${ }^{120}$

Em sua concepção de cultura brasileira, Oliveira Lima enxergava na ausência de uma linguagem popular brasileira o impedimento da "expressão de uma identidade própria", de modo que caberia institucionalmente à Academia Brasileira de Letras a legitimação de uma cultura brasileira pela subordinação aos "valores universais da língua e da cultura maternal", ou seja, mais uma vez explicitava a ligação com a Europa e sobretudo Portugal.

(Oliveira Lima) sempre atribuiu à ausência de um substrato linguístico popular o motivo que nos impediu de plasmar, com os elementos da terra, a expressão de uma identidade própria, (...) a crítica de Oliveira Lima elegeu a Academia como instância de legitimação da nossa cultura pelo viés da subordinação aos "valores universais da língua e da cultura materna". ${ }^{121}$

Assim, aqueles literatos que seriam responsáveis pela construção nacional, aquele que a ABL legitimaria como portadores de nossa cultura, foram por Oliveira Lima eleitos para uma espécie de "Panteão Nacional das Letras". Lá caberiam figuras reconhecidas pela sua "grandeza moral” e adequação da imaginação literária aos padrões estéticos europeus e lusitanos.

(...) a construção hermenêutica de um panteão nacional inspirado nos modelos consagrados pela tradição lusitana, o método de Oliveira Lima, mais do que descrever, analisar e avaliar a produção dos escritores brasileiros dentro de seu próprio sistema literário, o que faz é convertê-los num segmento secundário do sistema de origem, $(\ldots)$.

(...)

Isso sem falar que Machado de Assis, visto por ele, só é grande quando transformado num discípulo dos clássicos da língua - um Antonio Vieira, um Almeida Garret, a quem tem o mérito de nivelar-se pela "simplicidade do estilo" e pela "perspectiva inteiramente nova e original". É justamente esta a referência hermenêutica do panteão concebido por Oliveira Lima, pois é dele que irradiam as virtudes estético-literárias hauridas nos "espíritos superiores da imaginação e do pensamento", (...), espíritos estes em que de algum modo reverbera a vocação de Joaquim Nabuco, cujo "sentimento era brasileiro, mas a imaginação, européia". ${ }^{122}$

Esta visão de Oliveira Lima em seu posicionamento diante das pautas da ABL será fundamental nas análises que faremos no capítulo 3 sobre o objeto de estudo de nosso trabalho, os discursos de divulgação do Brasil no exterior.

\footnotetext{
${ }^{120}$ PRADO, Antônio Arnoni. Op.Cit. 2010.

121 PRADO, Antônio Arnoni. Op.Cit. 2010.

122 PRADO, Antônio Arnoni. Op.Cit. 2010.
} 


\subsection{3 - Itamaraty}

Vamos agora nos focar no Itamaraty, sua dinâmica e suas pautas no contexto da chancelaria Barão do Rio Branco. Com isto, espera-se compreender o panorama da política externa brasileira entre 1902 e 1912, contexto em que se insere o objeto de estudo deste trabalho.

Cabe aqui, entretanto, pontuar um entendimento - quase pressuposto - fundamental. Entendemos os diplomatas - posição social de Oliveira Lima em enfoque nestas próximas páginas - simultaneamente enquanto formuladores e executores de política externa. Assim, quando nos referimos aos diplomatas enquanto formuladores de política externa, entendemos sua posição enquanto intelectuais e executores da idéia de "Brasil no Mundo". A partir deste entendimento, colocamos os diplomatas enquanto intelectuais e homens de estado, portanto, o Itamaraty enquanto instituição ao mesmo tempo política e produtora de conhecimento.

Nossa análise sobre os diplomatas do Itamaraty se divide em dois momentos. Em um primeiro momento iremos apresentar o cenário político e econômico internacional no qual se insere a atividade em estudo. Buscaremos, em um segundo momento, estabelecer conexões entre os cenários, de modo a pontuar as reverberações das movimentações internacionais no Brasil, esclarecendo as questões em pauta da política externa brasileira e projetos de inserção do país no mundo.

O cenário internacional foi marcado por dois grandes movimentos: o apogeu da hegemonia global do sistema europeu e seu imperialismo, com consequências na configuração do sistema internacional e nas disputas geopolíticas; o início da transição da posição de centro da economia mundo capitalista da Grã-Bretanha para os Estados Unidos.

De modo a introduzir a discussão sobre este período, pode-se dizer que:

No âmbito mundial, o período entre 1871 e 1914-1918, caracteriza-se pelo apogeu da hegemonia global do sistema europeu. o "novo"imperialismo forçou a entrada no sistema internacional europeu daquelas partes do mundo que ainda estavam fora. Com isso, o imperialismo completou a construção de uma rede global de relações econômicas, estratégicas e políticas, que foram dominadas pelos principais Estados da Europa (WATSON,1992) ${ }^{123}$. Isso ocorreu de forma violenta, principalmente no contexto da partilha da África, da ocupação territorial de grande parte da Ásia e e da abertura da China. Após essa segunda onda de expansão colonial, não havia mais no mundo qualquer verdadeiro vácuo de poder. Com excessão da Áustria-Hungria, todas as grandes potências europeias, bem como os Estados Unidos e o Japão, entraram no circulo das potências coloniais, Durante o período de 1871 e 1914, as

123 Apud. WATSON, Adam. The evolution of the international society. A comparative historical analysis. London: Routledge, 1992. 
potências principais alçaram sua hegemonia, direta ou indireta, com relativa facilidade. Nunca, na história mundial, a brecha militar, tecnológica e econômica entre os Estados industrializados da Europa e o resto do mundo foi ou seria maior. Essa supremacia uniu-se, no final do século XIX, com uma decidida vontade européia de dominar o mundo.

Entretanto, os limites do poder europeu na escala mundial já eram perceptíveis durante a mesma época. Em primeiro lugar, os Estados Unidos alçaram-se, em poucos anos, depois do fim da Guerra Civil até a virada do século, à condição de primeira potência industrial do mundo. Isso porém, não se refletiu plenamente, até a Primeira Guerra Mundial, no ranking dos Estados Unidos entre as potências militares mundiais. ${ }^{124}$

Percebe-se, pelo exceto apresentado, o processo de expansão imperialista das grandes potências européias no mundo, assim como os limites deste processo com a ascensão econômica de países como os Estados Unidos. Ainda sobre este processo, uma outra visão vem no sentido de caracterizá-lo como uma fase de transição hegemônica e mundialização das relações internacionais:

Em fins do século XIX e nas primeiras décadas do século XX, assistiu-se ao debilitamento do predomínio mundial europeu e ao surgimento, em outras áreas do planeta, de novos pólos de poder: Estados Unidos, Japão e Rússia.

A globalização da economia, que se acentuou no período, e a formação de novos centros de poder resultaram na mundialização das relações internacionais. O sistema internacional, que tinha como focus a Europa, transformou-se em um sistema planetário. As partilhas territoriais e o estabelecimento de zonas de influencia faziam parte da política do equilíbrio que, nessa fase, já não encerrava nos limites do Velho Mundo. No final do século XIX, as diversas áreas fundiram-se num único sistema global. ${ }^{125}$

De modo a melhor compreendermos este processo de mundialização das relações internacionais e de expansão imperialista das grandes potências, cabe ainda analisarmos sua natureza, entendida aqui enquanto fenômeno de motivações econômico-políticas:

(...) Com efeito, nas três primeiras décadas imediatamente anteriores à Primeira Guerra Mundial (1914-1918), o crescimento industrial e comercial na Europa e nos Estados Unidos ensejou intensos movimentos internacionais de capitais. Poucas áreas do planeta não foram atingidas pelos investimentos capitalistas, num movimento tentacular. De um modo ou de outro, isto é, através da aplicação em empresas ligadas à produção ou ao transporte, sobretudo estradas de ferro, ou investimentos em empresas financeiras, os capitalistas buscavam, nos então chamados países "novos", rentabilidade que não mais conseguiam nos países de origem.

(...)

O afã dos monopólios capitalistas em investir fora dos países de origem, e a busca de saídas para produtos acabados teve como corolário o desenvolvimento de impérios coloniais. Pressionado pelas forças do capital, o imperialismo transformouse em instrumento da burguesia industrial, mesmo em prejuízo dos outros segmentos

${ }^{124}$ DOPCKE, Wolfgang. Apogeu e colapso do sistema internacional europeu (1871-1918). In: SARAIVA, José Flávio Sombra (Org.). História das Relações Internacionais Contemporâneas: da sociedade internacional do século XIX à era da globalização. São Paulo: Ed. Saraiva, 2008. p.78.

125 BUENO, Clodoaldo. Política externa da Primeira República: os anos de apogeu (1902 a 1918). São Paulo: Paz e Terra, 2003. p.29. 
da sociedade que não auferiam benefícios decorrentes da expansão. Os governos tornaram-se interpretes dos interesses das grandes empresas particulares. $\stackrel{A}{\text { medida }}$ que se aproximava o fim do século XIX, as questões de ordem financeira passaram a informar cada vez mais o relacionamento entre as nações. Interpretando e promovendo a riqueza do segmento burguês do respectivo país, os Estados irradiavam a concorreria interestatal a toda a sociedade, uma vez que seus interesses eram confundidos com os de toda coletividade. Assim, conforme a economia evoluía, aumentavam também os conflitos diplomáticos. A concorreria econômica, manifestada na procura de meios para a saída da produção, gerou inevitavelmente conflitos entre as potências capitalistas. ${ }^{126}$

Neste mesmo sentido - de um processo de expansão imperialista das grandes potências a partir de motivações sobretudo econômico-políticas - vai o entendimento de Eric Hobsbawm sobre o que denomina Era dos Impérios (1975-1914):

Um motivo geral mais convincente para a expansão colonial foi a procura de mercados. (...) Era amplamente disseminada a crença de que a "superprodução"da Grande Depressão poderia ser resolvida por meio de um vasto esforço de exportação. Os homens de negócios, sempre propensos a preencher os espaços em branco no mapa do comércio mundial com altos números de clientes potenciais, naturalmente procurariam estas áreas inexploradas (...).

Mas o ponto crucial da situação econômica global foi que um certo número de economias desenvolvidas sentiu simultaneamente a necessidade de novos mercados. Quando sua força era suficiente, seu ideal eram "portas abertas" nos mercados do mundo subdesenvolvido; caso contrário, elas tinham a esperança de conseguir para si territórios que, em virtude da sua dominação, garantissem à economia nacional uma posição monopolista ou ao menos uma vantagem substancial. A consequência lógica foi a repartição das partes não ocupadas do Terceiro Mundo. Em um certo sentido, tratava-se da extensão do protecionismo, que ganhou terreno em todas as partes após 1879 (...). Portanto, o "novo imperialismo" foi o subproduto natural de uma economia internacional baseada na rivalidade entre várias economias industriais concorrentes. Intensificada pela pressão econômica dos anos 1880. (...).

A essa altura, torna-se difícil separar os motivos econômicos para a aquisição de territórios coloniais da ação política necessária para este fim, pois o protecionismo de qualquer tipo é a economia operando com a ajuda da política. ${ }^{127}$

Assim, fica clara a natureza econômica e política do processo do "novo imperialismo", na qual motivações ligadas aos investimentos de capitais e busca de novos mercados se conectavam com pretensões geopolíticas das grandes potências.

Cabe ainda apresentar a dinâmica geopolítica do contexto, sobretudo no concerto europeu. A Grã-Bretanha, precursora do processo de industrialização, principal polo financeiro do sistema mundo capitalista e detentora de alta concentração de capital, ocupava a posição central na divisão internacional do trabalho. Possuía também os principais recursos bélicos - sobretudo navais -, além de apresentar-se como o maior dos impérios dada a vastidão e amplitude de suas possessões imperialistas.

\footnotetext{
${ }^{126}$ BUENO, Clodoaldo. Op. Cit., 2003. p. 27-28.

${ }^{127}$ HOBSBAWN, Eric J. A Era dos Impérios (1875-1914). 17 ed. Rio de Janeiro: Paz e Terra, 2014. p. 108-109.
} 
Interessante também é observar a posição da Alemanha, potência em ascensão no concerto europeu e em busca de seu lugar no processo imperialista:

(...). A partir de 1898, os alemães entravam no firme propósito de erigir seu país em grande potência naval, inclusive em razão da necessidade de expansão comercial, pois o crescimento da produção levava à busca de matérias-primas e de novos mercados. Fatores econômicos, portanto, ao lado de geopolíticos e do sentimento nacional, informavam a agressiva política externa alemã.

Ciente de sua força e potencialidades, a Alemanha, alimentada por forte componente nacionalista, passou a reivindicar um "lugar ao sol" na partilha do mundo, um lugar que parte da opinião alemã entendia como justo e direito, decorrente de saúde nacional. Os alemães não havia participado da partilha colonial. Uma vez realizada a unidade política do país e estando o organismo econômico em pleno vigor, desejavase recuperar o terreno perdido, pois chegara atrasada na partilha das áreas sujeitas à colonização. A presença econômica da Alemanha na América Latina foi também tardia em relação às demais nações industrializadas. ${ }^{128}$

Esta entrada tardia e postura agressiva da Alemanha de alguma forma alterou a dinâmica da competição imperialista entre as potências, fazendo com que as rivalidades se acentuassem por conta do medo do "perigo alemão". A escalada destas rivalidades é considerada como um dos fatores estruturais desencadeados da Primeira Guerra Mundial. O assunto, entretanto, foge da alçada do presente trabalho.

Dentro deste quadro mundial, a América Latina se insere na geopolítica e na divisão internacional do trabalho enquanto locus de interesses econômicos para os países centrais sobretudo Grã-Bretanha e EUA - por duas motivações: as trocas comerciais desiguais e os investimentos de capitais.

Cabe aqui salientar que a nova postura agressiva da Alemanha foi percebida e surtiu repercussões no que tange à América Latina, a partir de dois pontos de vista: às demais potências européias - e sobretudo à Grã-Bretanha - foi percebido como uma ameaça aos seus negócios e investimentos na região; aos países latino-americanos enquanto ameaça de rompimento dos laços econômicos com os países centrais e, principalmente, enquanto ameaça de intervenções imperialista - inclusive por vias bélicas - na região.

De modo a completar a contextualização do cenário mundial, cabe ainda esclarecer o início da transição da posição de centro da economia mundo capitalista e de principal potência geopolítica da Grã-Bretanha para os Estados Unidos:

Entre 1871 e 1914, o domínio europeu da economia mundial alcançou seu apogeu. Ao mesmo tempo, entretanto, um novo polo econômico, fora da Europa, tornou-se mundialmente perceptível, depois da virada do século, com a escalada industrial norte-americana. A arrancada industrial, por, dos Estados Unidos (entre 1880 e 1900,

${ }^{128}$ BUENO, Clodoaldo. Op. Cit., 2003. p.34. 
tornou-se o líder industrial do mundo) repercutiu com atraso no poder econômico mundial. O crescimento econômico do país, até a Primeira Guerra Mundial, era amplamente orientado para o mercado interno. (...). G. Arrighi ${ }^{129}$, não obstante, localiza já nessa época, ou, mais precisamente, no período da Grande Depressão de 1873 a 1896, a reviravolta decisiva na economia mundial. Segundo ele, é nessa crise que começa o "longo século XX", com a ascensão do "sistema norte-americano de acumulação em escala mundial e a derrocada do sistema britânico". ${ }^{130}$

Este processo de crescimento econômico dos Estados Unidos, apesar de ainda não alterar completamente o quadro da divisão internacional do trabalho, teve consequências em suas pretensões geopolíticas e alterou sua postura em direcionamentos de política externa, sobretudo com relação à América Latina. Foi neste contexto que emergiu o Corolário Roosevelt enquanto reinterpretação da Doutrina Monroe:

Só no último quartel do século XIX, os Estados Unidos voltaram a considerar a América Latina como um todo e formularam uma política exterior pan-americana com objetivos econômicos nítidos, embora em algumas subáreas (...) tenha pesado também, razões geopolíticas. (...). Originalmente concebida como proteção e nãoingerência, a Doutrina Monroe foi transformada em justificativa para sancionar intervenções em países latino-americanos abrangidos pela ampliação da área de segurança norte-americana. A Doutrina passou a ser invocada, também, para impedir que governos ou corporação estrangeiras adquirissem portos ou outros lugares que pudessem ameaçar as comunicações ou a segurança norte-americana. Ao afirmar o afastamento da ingerência européia no e invocar a Doutrina Monroe, o presidente Theodore Roosevelt (1901-1909) considerou, unilateralmente, a América Latina como parte do sistema internacional de poder norte-americano.

A aplicação dos princípios formulados por Monroe em1823, que vedavam o continente à conquista européia, impunha, na ótica de Roosevelt, responsabilidades. Aos Estados Unidos cumpria, assim, zelar pela ordem e pela paz no continente por meio de uma ação de polícia internacional.

(...)

O conceito de proteção do hemisfério contra agrestes extra-continentais, que era o seu cerne, foi assim, retrabalhado pelo então presidente norte-americano de forma a dar justificativa à política de coerção contra os Estados latino-americanos. As repúblicas da América Latina , conforme constatou o Evernin Post de Nova York, deveriam reconhecer suas obrigasse em troca da proteção dos Estados Unidos: " $A$ obra da Doutrina Monroe desenvolveu-se com a ação combinada das duas partes: a nação mais fraca, que precisa ser protegida contra a agressão estrangeira, e a nação poderosa, que estende sobre ela seu braço protetor. Suas obrigasse são mútuas" 131

Esta política ao mesmo tempo servia aos interesses econômicos e geopolíticos dos Estados Unidos, dava uma resposta às pretenções da Alemanha no continente LatinoAmericano e não feria aos interesses econômicos dos negócios e investimentos britânicos:

Como contrapartida da resistência a qualquer ingerência de potências extracontinentais na área, os Estados Unidos erigiram-se em gendarmes dos interesses europeus no continente. À Europa dava-se a garantia de que as nações

\footnotetext{
${ }^{129}$ ARRIGHI, Giovanni. O longo século XX. Dinheiro, poder e as origens de nosso tempo. São Paulo: Editora Unes, 1994.

${ }^{130}$ DOPCKE, Wolfgang. Op. Cit., 2008. p.86.

${ }^{131}$ BUENO, Clodoaldo. Op. Cit., 2003. p.43-44.
} 
latinas da América, sob a supervisão norte-americana, preservariam a ordem pública e manteriam seus compromissos em dia. Londres aplaudiu os termos do corolário Roosevelt A imprensa da Europa, principalmente a britânica, também aprovou a nova interpretação da Doutrina Monroe, uma vez que significava proteção para os investimentos. ${ }^{132}$

\section{O Corolário Roosevelt e sua política pan-americana repercutiu diferentes} posicionamentos dos diversos países Latino-Americanos. Mesmo internamente, houveram diferentes pontos de vista dos intelectuais e formuladores de política externa a respeito da questão.

Por hora, as questões levantadas até aqui nos parecem suficientes para a análise. Estes assuntos serão mais amplamente elaborado quando das discussões das pautas da política externa brasileira.

Neste segundo momento, analisaremos três aspectos do Itamaraty: sua dinâmica institucional, suas pautas de política externa e o posicionamento e projetos a respeito da inserção do "Brasil no Mundo". Analisaremos as posições de três dos principais diplomatas de então, formadores do que Hudson chamaria de núcleo de análise do Grupo: Barão do Rio Branco, Oliveira Lima e Joaquim Nabuco.

Do ponto de vista da dinâmica institucional do Itamaraty no período abarcado pelo presente estudo, adotaremos aqui a percepção de Zairo Chribub ao classificá-lo como $O$ Momento Carismático centrado na figura do Barão do Rio Branco:

O principal destaque deste período é a presença de um elemento carismático na figura do Barão. Esse carisma resulta, em parte, do fato de haver Rio Branco contribuído decisivamente para demarcar através de negociações e arbitragens internacionais as fronteiras do país, que vinham sendo objeto de disputas e conflitos durante quatro décadas. Rio Branco, antes mesmo de assumir a Pasta do Exterior, já havia defendido com sucesso duas disputas de fronteira - com a Argentina e com a França -, o que reforçava a idéia corrente de que a conclusão desta tarefa deveu-se ao seu carisma pessoal, ao seu empenho e interesse histórico pelas questões nacionais Durante sua permanência à frente do Itamaraty, esse carisma é reforçado, seja devido aos sucessos políticos do período em que chefiou o Ministério, seja ao seu estilo personalista de conduzir a administração pública. ${ }^{133}$

Assim, devido à seu carisma e prestígio pessoal, o Barão do Rio Branco enquanto chanceler acaba por centralizar a administração e as decisões da pasta, modificando a forma como se dava a dinâmica interna do MRE:

${ }^{132}$ BUENO, Clodoaldo. Op. Cit., 2003. p.44-45.

${ }^{133}$ CHEIBUB, Zairo Borges. Diplomacia e Construção Institucional: o Itamaraty em uma perspectiva histórica. In: Pensamiento Iberoamericano: Revista de Economia Politica. Madri: Instituto de Cooperación Iberoamericana, n.6, jul./dez. 1984. p.120-121. 
O caráter carismático de Rio Branco também alterou processos administrativos no Itamaraty. Devido ao seu estilo personalista, o Barão transformou totalmente a rotina de trabalho na Secretaria de Estado e centralizou toda a administração em torno de sua pessoa, evitando, assim, deixar-se prender pelos procedimentos rotineiros. ${ }^{134}$

Vale aqui pontuar que esta nova forma - carismática e pessoal - com que o Barão lida com a administração do Itamaraty foi o alvo das críticas e motivo do desentendimento entre Oliveira Lima e Rio Branco, conforme mencionamos mais acima no início deste capítulo.

Por sinal, temos aqui que pontuar uma característica marcante da personalidade de Oliveira Lima: o que Joaquim Nabuco chamou de "incontinência na pena". Oliveira Lima se envolvia de maneira talvez um pouco imprudente em suas polêmicas. Criticar publicamente seu chefe na condução do Itamaraty não parece ser atitude polida, ainda mais para um diplomata.

Gilberto Freyre veria esta mesma atitude com olhares um pouco mais doces: tratava-se de espécie de quixotismo intelectual. Chegou mesmo a dar o título de um livro seu de memórias da convivência com o nosso homem de letras de "Oliveira Lima, Don Quixote Gordo". ${ }^{135}$ À época, por volta dos anos 1920, Oliveira Lima já estava aposentado da carreira diplomática e lecionava Direito Internacional em universidades nos Estados Unidos. Freyre fora iniciar seus estudos em Columbia e encontrou em Oliveira Lima uma espécie amigo e tutor. Demos, assim, relativizar um pouco o tom ameno e quase fanfarrão das lembranças de Freyre.

O fato é que esta postura de Oliveira Lima para com o Barão do Rio Branco parece ter lhe custado alguns dissabores. Sobretudo com relação à disponibilidade do Barão com relação a Oliveira Lima nos assuntos dos corredores do Itamaraty. Não raras vezes, quando confrontado por remoções indesejadas acatava de bom grado pedidos enfurecidos de Lima para que fosse colocado em disponibilidade. Em outras palavras, aceitava e até estendia os prazos de licença de Oliveira Lima da carreira diplomática.

Por sinal, foi em suas licenças - duas delas, uma entre dezembro de 1902 e maio de 1905 e outra entre junho de 1906 e fevereiro de 1908 - que Oliveira Lima passou mais tempo no Brasil, seja no Engenho Cachoeirinha em Pernambuco - propriedade da família de sua esposa Flora, descendente da aristocracia açucareira pernambucana - onde se dedica leituras e alguns escritos, seja no Rio de Janeiro, onde aproveita para conviver fisicamente e de forma

\footnotetext{
${ }^{134}$ CHEIBUB, Zairo Borges. Op. Cit., 1984. p.121.

${ }^{135}$ FREYRE, Gilberto. Oliveira Lima, Don Quixote Gordo. Recife: Editora da UFPE, 1968.
} 
mais ativa de sua rede de sociabilidade intelectual, participando de sessões do IHGB e da ABL. ${ }^{136}$

Por sinal, é justamente quando está de nesta sua segunda licença como diplomata, no Rio de Janeiro, que Oliveira Lima consegue se dedicar com mais afinco à sua atividade historiográfica. É neste momento que faz pesquisas históricas, sobretudo na Biblioteca Nacional e no Real Gabinete Português de Leitura, e escreve seu Dom João VI no Brasil talvez sua obra mais prestigiada. Foi, portanto, período de ganhar prestígio perante seus pares homens de letras de modo a compensar a deterioração de sua relação como diplomata com seu Chanceler.

O Barão parece mesmo ter criado indisposições para com Lima no que diz respeito a remoções mais prestigiadas: as "civilizadas", ou seja, as capitais europeias. Por sinal, Oliveira Lima não escondia seu desejo em ser removido preferencialmente para a Europa. Além de serem postos mais prestigiados e de melhor posicionamento para a execução do que Oliveira Lima acreditava ser a atividade diplomática, queria estar próximo aos arquivos históricos europeus, fundamentais na pesquisa de fontes históricas necessárias para a produção historiográfica. Nos parece que há aqui alguns indícios que Oliveira Lima pensa ao mesmo tempo enquanto diplomata e homem de letras.

Retomando à dinâmica interna do ministério, podemos dizer que esta postura do Barão faz com que, por mais que haja disputas - a partir das mais diferentes pautas em voga - entre os diplomatas enquanto intelectuais do projeto de inserção internacional do Brasil, a decisão final sobre o projeto a ser implementado cabe a Rio Branco. E ele o faz menos com base em ideais e teorias, e mais enquanto um geopolítico, ou seja, de maneira pragmática e realista:

\begin{abstract}
O chanceler brasileiro pensou e agiu como um geopolítico, mas nunca citou autores da moda ou tentou adaptar a realidade à teoria. Foi, antes de tudo, um pragmático e teórico, e agiu guiado pelo bom senso, instinto e faro político e pela leitura do contexto internacional. Historiador e geógrafo, Rio Branco fazia suas análises partir das fontes e apegava-se à concretude dos fatos e ao devir histórico. (...).

Mas Rio Branco era afinado com seu tempo, o que permite inferi que conhecia os teóricos em voga, mas tinha idéias próprias de como manter a paz, defender e expandir o território acional e preservar-lhe a soberania.(...). Apesar do seu prestígio e influência, ele não levou a jeito uma política externa agressiva e arrogante escudada em ideias de projeção nacional. ${ }^{137}$
\end{abstract}

\footnotetext{
136 GOUVÊA, Fernando da Cruz. Oliveira Lima: uma Biografia. Recife: Instituto Arqueológico, Histórico e Geográfico de Pernambuco, 1973. vol 2.

${ }^{137}$ BUENO, Clodoaldo. Op. Cit., 2003. p.144.
} 
Baseado no carisma pessoal e na ação pragmática do Barão - tanto da leitura do cenário internacional, quanto dos interesses da elite política e econômica brasileira -, o Itamaraty gozou durante o período de autonomia institucional na condução da política externa:

Com o Barão do Rio Branco o Itamaraty desfrutou larga margem de autonomia na condução da policia externa. Não se pode, todavia, ver o homen de Estado como figura isolada, mas como produto de sua relação com o meio e interprete dos segmentos dominantes da sociedade. O homen de Estado no momento em que decide está sujeito a pressões, mesmo que sejam indiretas, do "meio ambiente". Conforme acentuou Duroselle, a idéia que o homem faz da conjuntura econômica ou política contribui em grande medida para a formação da decisão. Rio Branco permaneceu por tempo tão dilatado na chefia da pasta das relações exteriores, até porque sua policia ia ao encontro dos interesses das elites ligadas à agroexportação. Além disse, tentou pôr em prática uma grande politique, que satisfazia o nacionalismo brasileiro, alimentado na vastidão do território nacional, no potencial de suas riquezas, no crescimento demográfico, na prosperidade da lavoura comercial e na estabilidade das instituições políticas, consolidadas no quinquênio Campos Sales (1898-1902). ${ }^{138}$

Apesar disto, é necessário relativizarmos esta autonomia operacional com a concepção de que intelectualmente a política externa fora refletida e idealizada por intelectuais diplomatas inseridos simultaneamente e em conjunto em diversas outras disputas e pautas em diferentes redes de sociabilidade intelectuais - conforme visto no capítulo anterior.

Assim, feitas as considerações a respeito da dinâmica do Itamaraty durante a chancelaria Rio Branco, podemos agora explorar as diversas pautas da política externa brasileira. Faremos isto conectando-as com o contexto do cenário internacional e com os projetos de inserção e lugar do "Brasil no Mundo" de Rio Branco, Oliveira Lima e Nabuco.

Pode-se classificar as pautas da política externa brasileira do período em três eixos principais: a política territorial, as relações assimétricas de poder com as grandes potências e as relações de relativa simetria com os vizinhos sulamericanos. ${ }^{139}$

Assim, a primeira pauta a explorar é a política territorial, a partir da questão da definição das fronteiras nacionais do Brasil. Cabe logo de início ressaltar que esta pauta vinha desde antes da chancelaria Rio Branco, tendo o diplomata inclusive ganhado prestígio pessoal e carisma por conta de seu sucesso em atuação na questão, antes mesmo de assumir a pasta como explicitado quando da definição do Momento Carismático na dinâmica institucional do Itamaraty.

\footnotetext{
${ }^{138}$ BUENO, Clodoaldo. Op. Cit., 2003. p.127.

${ }^{139}$ RICUPERO, Rubens. Op. Cit., 2000. p. 27.
} 
Ao assumir a pasta o Barão deu prosseguimento a esta política, consolidado definitivamente as fronteiras nacionais:

\begin{abstract}
Antes de tornar-se ministro, o Barão deu, com a vitória nas arbitragens, contribuição decisiva para resolver as questões pendentes com a Argentina (1895) e com a França-Guiana Francesa (1900). Viriam, em seguida, as soluções para a fronteira com a Bolívia (Tratado de Petrópolis, de 1903), o Equador, com a ressalva dos eventuais direitos peruanos (1904), com o Peru, de forma provisória (1904) e mais tarde definitiva (1909), com a Inglaterra-Guiana Inglesa (laudo de 1904), com a Venezuela (1905), com a Holanda-Guiana Holandesa ou Suriname (1906), com a Colômbia (1907) e o tratado retificaria com o Uruguai (1909).
\end{abstract}

Não cabe a este trabalho explorar os acontecimentos e procedimentos políticos e jurídicos desta pauta. Isto porque não toca diretamente e tampouco influencia no nosso objeto de pesquisa. Além disso esta postura nos parece cabível a partir da constatação de não haver envolvimento direto nem intelectual parte de Oliveira Lima. Envolvimento prático houve apenas entre 1904 e 1905, quando serviu como Enviado Extraordinário e Ministro Plenipotenciário em Caracas, onde negociou o acordo de limites com o Governo Venezuelano. Constata-se também que a questão praticamente encerrou-se em 1907 - restando para 1909 apenas algumas delimitações finais, com a questão bastante adiantadas -, anterior, portanto à atividade de divulgação do Brasil praticada por nosso diplomata.

Sobre as relações assimétricas de poder com as grandes potências, cabe destacar a postura de temor com relação às intervenções das potências imperialistas no América Latina. Apesar de não se manifestar de maneira veemente no Brasil, a questão se colocava em pauta para o chanceler:

Outro aspecto do pensamento de Rio Branco que merece destaque diz respeito ao temor de eventuais agressões européias à América Latina. $\mathrm{O}$ receio que o imperialismo despertava, sobretudo pelas práticas agressivas com que, normalmente, se manifestava, ${ }^{140}$ era um sentimento presente na época. Rio Branco não escapava do espírito do seu tempo, mas não era um obcecado que via agressão por toda parte. Isso não o impedia de se respaldar na repulsa que o imperialismo provocava na opinião pública, para agir com a firmeza que fosse necessária para impedir que a soberania nacional fosse arranhada. ${ }^{141}$

O temor à soberania do Brasil em face ao imperialismo, provocava diferentes pensamentos em Rio Branco, Joaquim Nabuco e Oliveira Lima sobre qual deveria ser a postura do país perante os as relações assimétricas e simétricas, acarretando assim diferentes

\footnotetext{
140 * A prática imperialista não significava apenas conquistas territoriais; manifestava-se às vezes na forma de pressão armada, a título de cobrança de dívidas ou na "defesa"de interesses ameaçados. BUENO, Clodoaldo. Op. Cit., 2003. p. 133.
}

${ }^{141}$ BUENO, Clodoaldo. Op. Cit., 2003. p. 132-133. 
projetos de inserção do Brasil no mundo e diferentes estratégias de execução da política externa.

O chanceler acreditava que a melhor estratégia seria garantir a estabilidade política da região. Esta estratégia derivava, em parte, da "visão de mundo" comum à época de que as intervenções viriam a ocorrer caso os "países civilizados" - os europeus - constatassem que os países latino-americanos estivessem a se comportar como "países bárbaros", instáveis internamente e na relação com os vizinhos - e sujeitos a diversas convulsões políticas. ${ }^{142}$

Acreditava também que para garantir esta estabilidade na região o Brasil deveria buscar elevar seu prestígio perante suas relações assimétricas - Europa e Estados Unidos - de modo a ganhar confiança destes países com relação à estrutura política e ao comportamento "civilizado" do país. Elevar o prestígio do Brasil significava, para o Barão, ganhar maior relevância no cenário internacional, de forma a garantir a soberania do país e um maior grau de autonomia em suas operações diplomáticas. ${ }^{143}$

Nabuco também via a ameaça vinda principalmente dos imperialismo europeus, sobretudo por parte da Grã-Bretanha e Alemanha. Apesar de algumas preocupações, não via grandes pretenções imperialistas na região por parte dos Estados Unidos, de forma que acreditava que uma aproximação do Brasil com os norte-americanos seria a melhor estratégia a ser implementada. Esta estratégia deriva da crença de que a Doutrina Monroe - e mesmo o Corolário Roosevelt, observado de perto por Nabuco, à ocasião o primeiro Embaixador do Brasil em Washington - era algo positivo para a região e que o Brasil deveria apoiar os Estados Unidos nesta doutrina, colocando-se enquanto um parceiro deste na sub-região sulamericana: 144 "Eu sou um forte monroista... e por isso grande partidário da aproximação cada vez maior entre o Brasil e os Estados Unidos" "145

Oliveira Lima também percebia a ameaça do imperialismo europeu, mas, diferente de Nabuco, tinha uma postura mais resistente com relação às pretenções e posturas dos Estados Unidos. Apesar de ser simpático às idéias pan-americanas da Doutrina Monroe enxergava pretenções imperialistas no Corolário Roosevelt, sobretudo após o episódio de intervenção

\footnotetext{
${ }^{142}$ BUENO, Clodoaldo. Op. Cit., 2003. p. 128-134.

${ }^{143}$ BUENO, Clodoaldo. Op. Cit., 2003. p.135-143.

144 BETHELL, Leslie. Nabuco e o Brasil entre Europa, Estados Unidos e América Latina. In: Dossiê Joaquim Nabuco. In: Novos Estudos. São Paulo: CEBRAP, n. 88, dez. 2010. p.70-82.

145 Apud. BETHELL, Leslie. Op. Cit., 2010. p.81.
} 
norte-americana na Venezuela em 1902 e em São Domingos em 1904. Assim, Oliveira Lima era menos otimista que Nabuco com relação à aproximação com os Estados Unidos. ${ }^{146}$

Posta esta ressalva, Oliveira Lima via na manutenção das boas relações com os países europeus a melhor postura a fim de evitar intervenções. Mais do que isto, arriscamos dizer que esta estratégia está intimamente conectada à visão que Lima tinha a respeito da questão da nacionalidade, ou melhor, da cultura brasileira e da formação histórica da nacionalidade brasileira - já pontuadas e exploradas em outros momentos desse capítulo -, ligada à tradição européia por vias lusitanas e, portanto, com um padrão também "civilizado". Em suma, podemos inferir que Oliveira Lima acreditava que mostrar aos europeu uma conexão, uma empatia, entre esses e o Brasil seria a melhor forma de garantir as boas relações e a não intervenção.

Outra pauta nas relações assimétricas é a já levantada questão da aproximação com os Estados Unidos. Vimos, pelas posturas com relação aos imperialismos, as posições de Nabuco e Lima com relação ao tema: um entusiasta e outro mais ressabiado. Por sinal, estas posições diversas sobre a questão foi pauta de umas uma das "incontinências da pena" de Oliveira Lima. Atacava publicamente a honra de Joaquim Nabuco a respeito de suas posturas com relação aos Estados Unidos, sobretudo quando da realização da 3a Conferência Panamericana de 1906. Realizada no Rio de Janeiro, era vista como importante para a articulação política do pan-americanismo, seja num projeto aos olhos latino americanos, seja num projeto aos olhos dos Estados Unidos. Entretanto a Conferência teve como tônica a intensa articulação por parte de Nabuco para aproximar, via Brasil, os Estados Unidos dos países Latino Americanos, numa postura aos olhos de Oliveira Lima condescendente - e até intriguista, diga-se - com o relação ao Corolário Roosevelt.

A polêmica causou grandes incômodos e levou ao rompimento da amizade dos diplomatas, amizade esta que vinha desde 1882 quando Oliveira Lima era apenas um jovem estudante em Portugal e publicava em sua revista mensal Correio do Brasil cartas elogiosas a Nabuco, então uma espécie de "celebridade nacional" por conta de sua campanha abolicionista. As cartas rendiam também elogios por parte de Nabuco ao jovem promissor Lima e certamente foram importantes na aceitação e prestígio de Oliveira Lima nas redes de sociabilidade intelectual, seja na $\mathrm{ABL}$, seja nos corredores do Itamaraty.

${ }^{146}$ MALATIAN, Teresa. Op. Cit., 2001. p.185-186. 
Interessante, ainda, é observar a postura mais uma vez pragmática de Rio Branco: soube observar o movimento de aumento de poder econômico e geopolítico dos Estados Unidos dado o processo de transição da posição de centro da economia mundo capitalista, ao mesmo tempo em que percebeu os interesses da elite política e econômica agroexportadora brasileira no país. Assim, defendeu política externa de aproximação com os Estados Unidos. Entretanto, também foi pragmático ao não se distanciar da Europa, tentando maximizar os ganhos para o Brasil num jogo de duplo movimento:

\begin{abstract}
Parece que Rio Branco procurou fazer um jogo de duplo movimento, ao mesmo tempo aproximando-se da esfera de influencia norte-americana por razões comerciais e estratégicas (aval para a resolução de questões fronteiriças) e mantendo ligações com a Europa. de onde vinham investimentos e trabalhadores. Atendia, assim, aos interesses da oligarquia agroexportadora e à emergência dos Estados Unidos no cenário mundial como potência. Rio Branco não se posicionou contra o Corolário Roosevelt, pois não considerava como possibilidade uma intervenção norte-americana no Brasil, injustificada no contexto que apresentava como de estabilidade institucional, saneamento financeiro e prosperidade da cafeicultura. ${ }^{147}$
\end{abstract}

Esta postura de Rio Branco resume o posicionamento do Brasil com relação à seus relacionamentos assimétricos: o meio termo pragmático entre a visão de Nabuco e Oliveira Lima, o meio termo pragmático entre a aproximação com os Estados Unidos e a manutenção das relações com a Europa.

Em se tratando do eixo das relações simétricas com os vizinhos sulamericanos, cabe a este trabalho apenas pontuar os esforços do Brasil em elevar seu prestígio de modo a ganhar a confiança destes para o discurso da ausência de pretensões imperialistas do Brasil na região.

Neste sentido vale pontuar a elaboração da Revista Americana. Tratava-se de publicação do MRE na qual diplomatas e homens de letras de diversos países latinoamericanos escreviam artigos e ensaios sobre temáticas da política e da cultura da região.

Na prática, a intenção parecia ser a criação de um canal simbólico de confecção entre as nações latino-americanos. Entendemos que aqui o Barão do Rio Branco lançava para o eixo simétrico uma ferramenta e estratégia semelhante àquela desempenhada por Oliveira Lima para a Europa no eixo assimétrico: criar uma conexão e fortalecer os laços a partir de uma mútua divulgação cultural.

Agora de maneira mais pontual, podemos dizer que a estratégia do país para elevar seu prestígio perante seus vizinhos foi, por um lado, via condução de acordos bilaterais das definição de fronteira e, por outro lado, via participação do Brasil nas Conferências Pan-

${ }^{147}$ MALATIAN, Teresa. Op. Cit., 2001. p.187. 
Americanas, a destacar a disponibilidade do Brasil em ser sede da 3a Conferência a realizar-se no Rio de Janeiro em 1906.

Sobre esta Conferência, é interessante observar um excerto do discurso de abertura dos trabalhos, pronunciado pelo Barão do Rio Branco:

(...) É preciso, pois, afirmar que, formal ou implicitamente, todos os interesses serão por nós respeitados; que na discussão dos problemas políticos e comerciais, submetidos ao exame da Conferência, ela não trabalha contra ninguém e só visa a maior aproximação entre os povos americanos, o seu bem estar e rápido progresso, com que a Europa e as outras partes do mundo só têm as ganhar.

Nações ainda novas, não podemos esquecer o que devemos aos formadores do capital com que entramos na concorrência social. À própria vastidão de nossos territórios, em grande parte desertos, inexplorados alguns, e a certeza de que temos recursos para que neste continente viva com largueza uma população dez, vinte vezes maior, nos aconselhariam a estreitar cada vez mais as relações de boa amizade, a procurar desenvolver as de comércio com esse inexaurível viveiro de homens e fonte prodigiosa de energias fecundas que é a Europa. Ela nos criou, ela nos ensinou, delas recebemos incessantemente apoio e exemplo, a claridade da ciência e da arte, as comodidades da sua indústria, e a lição mais proveitosa do progresso. O que em troca desse inapreciável continente moral e material, lhe pudermos dar, crescendo e prosperando, será, certamente, um campo mais importante para o emprego da sua atividade comercial e industrial. ${ }^{148}$

Podemos dizer que, neste discurso, o chanceler estabelece com a América Latina a mesma relação anteriormente estabelecida apenas com relançar à aproximação com os Estados Unidos: faz novamente um jogo duplo ao aproximar-se dos vizinhos continentais por meio do pan-americanismo ao mesmo tempo em que mantém os vínculos com a Europa a partir de uma exaltação da importância do continente para a formação latino-americana.

Arriscamos dizer que neste pronunciamento Rio Branco, apesar dos desentendimentos pessoais, de alguma maneira prestigia a visão e projeto de inserção internacional do Brasil de Oliveira Lima. Entendemos que aqui o chanceler estabelece de maneira clara a importância da manutenção das relações com a Europa, abrindo caminho para entendermos melhor a atividade de divulgação do Brasil empreendida por Oliveira Lima. Isto vem de encontro com uma das nossas preocupação centrais da pesquisa, sobre a possibilidade da atividade ser encarada enquanto política externa.

148 GARCIA, Eugênio Vargas. Diplomacia brasileira e politica exterior: documentos históricos (1493-2008). Rio de Janeiro: Contraponto, 2008. p.359-360. 


\section{Capítulo 3 - A divulgação do Brasil no exterior (1908 - 1912)}

Este terceiro capítulo tem como objetivo descrever e problematizar a atividade de Oliveira Lima em questão, qual seja os discursos proferidos entre 1908 e 1912 na Europa e em que versa sobre questões da cultura do Brasil. Para tal, buscaremos analisar tanto o texto em suas estratégias argumentativas, na identificação de alguns conceitos fundamentais adotados pelo autor, como em seus contextos mais imediatos de produção, na identificação de cenários, atores e recepção dos discursos.

Em seguida, vamos propor uma reflexão sobre o sentido da divulgação, de modo a articular diversas questões levantadas ao longo do trabalho. Por fim, buscaremos dar conta de explicar como se deu o final do processo em estudo.

A atividade acorreu de forma mais intensa entre os anos de 1908 e 1912, período correspondente àquele em que o diplomata ocupou o cargo de Ministro Plenipotenciário da Legação do Brasil em Bruxelas, acumulando à esta função a representação do Brasil em Estocolmo. ${ }^{149}$

A nomeação de Oliveira Lima para Bruxelas foi complicada. Mencionamos no capítulo anterior as dificuldades colocadas pelo Barão do Rio Branco com relação a remoções de Oliveira Lima para postos na Europa. Neste caso não foi diferente. Apos um longo período em licença no Rio de Janeiro, nos parece que Oliveira Lima tinha mesmo quase desistido da carreira diplomática por conta de suas complicada pessoais com o chefe.

Foram necessárias as intervenções de alguns de seus interlocutores e amigos de sua rede de sociabilidade intelectual - em especial de Salvador de Mendonça e de José Veríssimo e até de uma arriscada carta pessoal de Lima para o Presidente da República Afonso Pena colocando-se em disponibilidade, ou seja, praticamente pedindo sua aposentadoria, caso não conseguisse um posto na Europa. Vale dizer ainda que parece ter contando também com a intervenção de alguns laços que Lima estabeleceu com a elite paulistana em viagem recente que fizera a São Paulo e dos contatos que estabelecera com o IHGSP. No final das contas, nos parece que Oliveira Lima conseguiu sua remoção à Europa, a contragosto do Barão, muito por conta de seu prestígio acumulado enquanto homem de letras.

${ }^{149}$ MALATIAN, Teresa. Op. Cit., 2001. p.227. 
Vale lembrar que no período entre 1906 e 1908, em que esteve de licença no Rio de Janeiro, Oliveira Lima aproveitou para estreitar relações com seus pares homens de letras, participar de sessões do IHGB e da ABL, fazer pesquisas históricas e escrever sua obra mais prestigiada, Dom João VI no Brasil, publicado em 1908, ano de sua chegada à Bruxelas. Entendemos, assim, que Oliveira Lima gozava naquele momento específico de grande prestígio intelectual.

É bem verdade que Bruxelas não é Paris. Muito menos Londres. Mas este posto de segundo escalão europeu era a chance que Oliveira Lima tinha de estar na Europa, de estabelecer relações com homens de letras "civilizados" e estar próximo dos arquivos históricos e dos congressos e reuniões intelectuais. A nomeação nos parece ter também reanimado suas esperanças na carreira diplomática e de sonhar com postos mais prestigiados no futuro caso fizesse um bom trabalho.

Isto significava que ele via ali a chance de exercer política externa à moderna no seu ponto de vista, buscando estreitar relações comerciais - questão que entendia como fundamental e que achava pouco explorada pelo Barão - e estabelecer aproximações políticas por meio daquilo que lhe dava poder e prestígio pessoal e que deveria ser a base de sua sustentação e progresso na carreira: o fato de ser ao mesmo tempo um homem de letras e um diplomata, ou seja, o fato de poder exercer uma política externa cultural. Sentido este que, por sinal, entendemos ir ao encontro das posições de Oliveira Lima na questão da constituição da nacionalidade.

Antes de entrarmos na análise de nosso objeto, vale aqui pontuar um primeiro momento em que Oliveira Lima realizou sua atividade de divulgação do Brasil no exterior. Tratou-se de uma Conferência para o Getsu Yo Kwai (Mondey Club de Tóquio) em que o diplomata apresentou o Brasil a um grupo de senhoras japonesas, pontuando alguns aspectos de seu povo e sua formação histórica. Tal conferência ocorreu em 1902 quando ainda exercia a função de Encarregado de Negócios junto à legação do Brasil em Tóquio, antes, portanto, de se empenhar mais intensamente à questão como ocorrerá a partir de 1908, já na Europa. ${ }^{150}$

Assim como Vellozo vê na experiência que Oliveira Liam teve no Japão um momento de ruptura em sua trajetória intelectual por identificar ali uma inflexão na maneira como Lima vê, do ponto de vista historiografia a questão da formação histórica da nacionalidade 
brasileira - conforme observamos no capítulo anterior - vemos também nessa sua experiência no Getsu Yo Kwai um momento em que Oliveira Lima percebeu que poderia se valer desta estratégia para ao mesmo tempo dialogar sobre questões da nacionalidade e exercer política externa.

Partiremos, enfim, para a descrição de cada uma das ocasiões em que o diplomata atuou no âmbito da atividade de divulgação do Brasil no exterior. Paralelamente faremos um esforço de problematizar a atividade de modo a pontuar algumas reflexões em curso a respeito das intencionalidades e interesses dos atores envolvidos, os públicos que se tinham em mente e, finalmente, os meios e mecanismos de sociabilidade pelos quais a atividade se viabilizava.

Em sua atividade de divulgação do Brasil a partir de 1908 a temática da formação histórica passou a ser abordada por Oliveira Lima na forma de Conferências em Congressos e Universidades e de artigos para revistas especializadas em crítica literária.. ${ }^{151}$ Vale aqui relembrarmos brevemente a maneira como Lima entende a questão da nacionalidade brasileira.

Dada a inserção do Brasil no mundo a partir da empresa colonizadora portuguesa, a vinda da família real para o Brasil, a elevação do país a Reino Unido e o processo de independência do Brasil, o Oliveira Lima historiador da formação da nacionalidade brasileira compreende que os referenciais da herança lusitana servem de elementos para que compreenda o país enquanto "Nação civilizada", equiparando-o portanto às Nações Europeias. Mais do que isto, Oliveira Lima entende que não houve rompimentos com relação a Portugal em nenhum desses acontecimentos; muito pelo contrário, o que caracteriza a nacionalidade brasileira são justamente as continuidades com relação a Portugal, e consequentemente, com relação à Europa.

\section{1 - A atividade de divulgação}

\subsection{1 - Conferências}

A primeira das conferências sobre a temática foi realizada em 1908 no Congresso Geográfico de Genebra sob o título de Le Brésil, seus Limites Actuelles, seus Voies de

${ }^{151}$ SOBRINHO, Barbosa Lima (Org.). Op. Cit., 1971. p.65. 
Pénétration. O Congresso fora realizado pelo Conselho Federal da Confederação Helvética, uma espécie de órgão do governo suíço, e contou com a presença de representantes oficiais de Nações convidadas e intelectuais vindos de Universidades e Academias, sobretudo de Nações europeias e americanas. Oliveira Lima fora àquele Congresso como delegado oficial do Estado brasileiro, a ordens de seu Chanceler. Segue abaixo transcrição do telegrama enviado por Rio Branco.

\footnotetext{
Vossência e vice cônsul Georlette nomeados delegados Brasil nono Congresso Geográfico Genebra reunião 27 julho a 6 agosto ponto Queira previnir Georlette e por ofício cônsul Bulcão sobre comissão Georlette ponto Para despesas viagem estada terão cada um hum conto de réis ponto. Poderão sacar depois de aviso do Delegado ponto Ministro em Berna remeterá programa

Rio Branco ${ }^{152}$
}

Entendemos que o Itamaraty se aproveitava do fato de Oliveira Lima estar na Europa para se valer de seu perfil intelectual em prol dos serviço diplomático. A convocação, vinda de Rio Branco, mostra que apesar de toda a resistência do Chanceler em nomear Lima para um posto europeu, uma vez efetuada a remoção sabia manejar seu encarregado em prol dos interesses diplomáticos.

Infelizmente, não conseguimos acesso ao texto da apresentação de Oliveira Lima. A bibliografia consultada apontava para a publicação da apresentação no jornal O Estado de São Paulo, nos dias 24 e 30 de agosto e 02, 06 e 08 de setembro de 1908. Entretanto, o que encontramos no jornal nestas datas foi a publicação, em cinco partes, de relatos de Oliveira Lima sobre o Congresso Geográfico de Genebra. Tratam-se mais de espécie de relatos de viagem, no qual Lima descreve a paisagem e o cotidiano de Genebra durante sua estada na cidade.

Pelo que pudemos observar dos relatos especificamente sobre a apresentação de Oliveira Lima, entitulada Le Brésil, seus Limites Actuelles, seus Voies de Pénétration, constatamos que Lima tratou primordialmente da formação histórica das fronteiras brasileiras, assunto conectado com a questão da definição das fronteiras nacionais, processo a ser concluído em 1909 pela política externa da chancelaria Rio Branco.

Talvez Oliveira Lima pretendesse demonstrar para seu público ouvinte as novas configurações fronteiriças do Brasil e a maneira diplomática e pacífica como foram

\footnotetext{
152 Telegrama datado de 24 de junho de 1908. Arquivo Histórico MRE.
} 
estabelecidas, de modo a elevar o prestígio do país perante as Nações europeias. ${ }^{153}$ Vemos que assim a apresentação pode ter tido, como objetivo, dentre outras pautas, garantir que o Brasil não sofresse intervenções imperialistas por parte das potências europeias. Assim, podemos entender esta apresentação como um elemento no sentido de uma política cultural externa executada por Oliveira Lima.

Ainda em 1908, nosso diplomata fora mais uma vez designado por Rio Branco como delegado do Governo brasileiro, desta vez para o Congresso Internacional dos Americanistas em Viena. Esta seria a 16a edição do Congresso, organizado a cada ano eum uma sede diferente pela Sociedade Internacional dos Americanistas, instituição que congregava intelectuais especializados em questões americanas. De maneira semelhante ao Congresso Geográfico de Genebra, eram convidados a estas reuniões representantes oficiais de Nações convidadas e intelectuais vindos de Universidades e Academias. ${ }^{154}$

Desta vez, Oliveira Lima pronunciou a conferência Sur L'Évolution d’une Ville $d u$ Nouveau Monde, du XVIème au XXe Siècle - À pros de la Récente Transformation du Rio de Janeiro, na qual tratou de descrever a formação histórica da cidade do Rio de Janeiro além de destacar as atuais transformações urbanísticas pelas quais a cidade se submetia a fim de se modernizar.

Cabe aqui ressaltar o esforço do diplomata em demonstrar como a cidade do Rio de Janeiro - então Capital da República - vinha sendo modernizada a fim de se enquadrar nos critérios europeus de civilidade e higienização, ao modelo das reformas urbanas de Hausmann em Paris. ${ }^{155}$

Como voz disse, mais de 600 casas, pela maior parte da época colonial, foram demolidas só no bairro commercial, para abrir lugar a uma das mais bellas avenidas do mundo, bordadas de edifícios sumptuosos e indo do mar ao mar, enquanto uma outra avenida acompanha numa enorme extensão as sintiosidades das praias, deixando admirar de um lado a bahia magnífica e do outro esplêndido secuário de montanhas e de florestas. ${ }^{156}$

\footnotetext{
${ }^{153}$ RICUPERO, Rubens. Rio Branco: o Brasil no mundo. Rio de Janeiro: Contraponto, 2000.

${ }^{154}$ GOUVÊA, Fernando da Cruz. Op. Cit., 1973. p.786-790.

155 CARVALHO, José Murilo de. Op. Cit., 2003.

${ }^{156}$ LIMA, Manuel de Oliveira. Sobre a evolução d’uma cidade do Novo Mundo do XVI ao XX século, a propósito da recente transformação do Rio de Janeiro. In: O Estado de São Paulo, anno XXXIV, No 10893, 06 de outubro de 1908. p.1.
} 
Vemos aí um exemplo de que o Brasil não somente procurava se adequar aos padrões de urbanidade europeus, com a abertura de novos boulevad, como adaptava este padrão às características locais, marcada pela presença da natureza.

Entretanto, esta adaptação se dava numa equação em que a cidade reformada se colocava como o espaço de convivência da civilização e a natureza, bárbara e tropical, se apresentava como exuberante cenário, à distância. É como se o elegante cavalheiro pudesse flanar nas novas e belas avenidas e observar confortavelmente os esplendores da paisagem tropical, como se fosse um retrato ao céu aberto. Eis aí o Rio de Janeiro apresentado ao Mundo com uma bela capital da "Civilização nos Trópicos".

Entretanto nos parece que Oliveira Lima apresenta em sua conferência sobre o Rio de Janeiro uma visão evolucionista do processo histórico, muito semelhante aos moldes que desenvolvemos no primeiro capítulo. Aliás, o próprio título já denuncia esta característica. Esta visão se destaca sobretudo no trecho abaixo:

\begin{abstract}
As cidades do Novo Mundo (...) oferecem um exemplo, notável no esforço, da longa evolução humana. Em três ou quatro séculos ellas passaram do estado de natureza ao estado de cultura, da animalidade completa a uma civilização refinada. Não falo dessas cidades americanas, muito típicas de resto, que nascem já crescidas e até ostentando de artifícios modernos. São estes casos de geração espontânea ou algumas vezes de maturidade precoce, que nem são exclusivos dos Estados Unidos. A nossa cidade de Bello Horizonte, no Brasil, a nova capital de Minas Gerais, nasceu em condições semelhantes. A cidade do Rio de Janeiro, capital do Brasil, forma pelo contrário um bello exemplo de uma cidade que passou por todas as phases, (ilegível) todas as formas, passou sucessivamente em três séculos e meio por todas as transformações que Roma atravessou em vinte séculos. ${ }^{157}$
\end{abstract}

Este discurso nos parece mais um exemplo de empenho de Oliveira Lima em se comunicar com seus ouvintes no Congresso no sentido de buscar estreitar relações com as "Nações civilizadas". Do mesmo modo, nos parece que busca também se reportar e estabelecer diálogo com seus pares Homens de Letras no Brasil, sobretudo ao escolher tratar da cidade do Rio de Janeiro a partir do ponto de vista historiográfico. Aliás, nos parece que aqui é também um exemplo do novo paradigma historiográfico, com elementos modernos de escrita ao mesmo tempo em que se mantém uma visão vinda dos pensamentos do XIX.

Ainda neste Congresso Internacional dos Americanistas em Viena, Gouvea nos relata sobre as articulações empreendidas por Oliveira Lima para que a língua portuguesa fosse reconhecida como língua oficial nos próximos congressos, assim como seu empenho em fazer

${ }^{157}$ LIMA, Manuel de Oliveira. Op.Cit. In: O Estado de São Paulo, anno XXXIV, No 10893, 06 de outubro de 1908. p.1. 
realizar a próxima edição do Congresso na cidade do Rio de Janeiro. Conseguiu que a língua portuguesa fosse adotada oficialmente, mas falhou em trazer a Conferência para o Brasil. É interessante ainda notar nos relatos de Gouvea que aparentemente Rio Branco não se empenhou muito em dar respaldo a Lima nessas duas articulações, o que pode ter dificultado o processo, sobretudo na candidatura do Rio de Janeiro. ${ }^{158}$

Talvez estejamos aqui em um caso no qual Oliveira Lima, apesar de representante oficial do governo brasileiro, passa a atuar de maneira mais, digamos, independente. Ou, ainda estivesse sendo deliberadamente isolado por Rio Branco, como que num jogo em que hora o Chanceler apresenta aproximações, hora distanciamentos, como que para melhor controlar o processo ao seus interesses e articulações. Ainda assim, nos parece que tanto o discurso como as duas iniciativas de Oliveira Lima no Congresso, são demonstrações de política cultural externa.

A questão do empenho de Lima na oficialização da língua portuguesa nos Congressos Internacionais dos Americanistas nos serve de conexão para uma outra Conferencia na qual Lima discursou, desta vez em 1909 na Universidade de Louvain, Bélgica. Seu discurso foi justamente sobre La Langue Portugaise, la Littérature Brésilienne. ${ }^{159}$

Já tendo estabelecido alguns contatos entre os Homens de Letras europeus, Oliveira Lima fora convidado pela Universidade de Louvain a discursar, na condição de intelectual, sobre questões pertinentes à cultura brasileira. É bem verdade que Lima era também Ministro Plenipotenciário do Brasil em Bruxelas, portanto representante oficial do governo brasileiro junto ao governo belga, o que lhe dava maior credibilidade para falar sobre as "coisas do Brasil”.

Em seu discurso Oliveira Lima se dedicou, a princípio, em demonstrar o processo de formação da língua portuguesa, evidenciando as decisivas influências da tradição latina, via expansão romana.

(...) Esquecia-se em demasia que outros elementos tinham entrado na combinação, mas, o facto é que os dois idiomas, o português e o hespanhol, tinham perdido para todo sempre seu typo local e primitivo e adquirido seu caráter definitivo debaixo da poderosa ação romana. Roma foi a influência civilizadora, foi ella que organizou administrativamente, religiosamente, militarmente, juridicamente essa região hispânica inculta na moral tanto quanto no physico.

\footnotetext{
158 GOUVÊA, Fernando da Cruz. Op. Cit., 1973. p.786-790.

${ }^{159}$ GOUVÊA, Fernando da Cruz. Op. Cit., 1973. p.815.
} 
Não é pois de surprehender que a sua língua se transformasse no que justamente se appelidou línguas neo-latinas, distintas desde o momento em que a história de cada uma das duas nações da península tomou uma direcção diferente. ${ }^{160}$

Vemos neste relato que Oliveira Lima considerava que Roma cumprira na península ibérica um "ação civilizadora", sendo crucial na composição da língua portuguesa, considerado como uma língua neo-latina. É como se a cultura portuguesa, via sua língua, se conectasse à tradição latina, portanto civilizada.

Em seguida Lima faz um esforço do ponto de vista da formação literária no mesmo sentido das Conferências anteriores onde discursou no sentido da historiografia: busca conectar aspectos da nacionalidade brasileira à tradição europeia, por vias lusitanas. Neste caso específico, se empenhou em demonstrar as continuidades do Brasil com relação a Portugal a partir da língua portuguesa. Procurou também analisar a literatura brasileira a partir de um prisma da tradição europeia, destacando novamente a questão das continuidades.

Vale aqui pontuar um aspecto que o leitor já deve ter notado. Estas três primeira $\mathrm{s}$ Conferências, pronunciadas em francês por Oliveira Lima na Europa, foram depois traduzidas por ele mesmo para português e publicadas em forma de artigo no jornal O Estado de São Paulo. Lima havia se tornado correspondente internacional do jornal a convite de Júlio Mesquita, de quem se aproximara quando de sua passagem por São Paulo antes da remoção a Bruxelas.

Além de manter posição de destaque enquanto Homem de Letras, entendemos que este movimento de tradução e publicação de suas conferencias no jornal O Estado de São Paulo representa o intento de Oliveira Lima de fazer ver no Brasil o seu trabalho realizado na Europa. Mais do que isto, é uma maneira de Lima estabelecer diálogo de seus textos com seus pares brasileiros.

Colocado de outra maneira, as publicação no Brasil de suas conferências serve para mostrar a seus pares que estava os representando na Europa enquanto Homens de Letras, ao mesmo tempo em que possibilita que seus textos entrem no circuito dos diálogos e discussões que se faziam no Brasil a respeito da questão da nacionalidade. Interessante ainda notar que Oliveira Lima trata justamente de questões pertinentes ao IHGB e à ABL, instituições produtoras de conhecimento na qual circulava sua rede de sociabilidade intelectual.

\footnotetext{
${ }^{160}$ LIMA, Manuel de Oliveira. A Lingua Portugueza. In: O Estado de São Paulo, anno XXXV, No 11024, 14 de
} fevereiro de 1909. p.1. 
Outro encontro a que Oliveira Lima compareceu e discursou como delegado oficial do Brasil foi o Congresso Internacional de História Musical, realizado em Viena no ano de 1909. Segue abaixo transcrição de mais um telegrama do Barão:

\begin{abstract}
Oliveira Lima - Legação Brasileira - Bruxelas
Fim maio reuni-se Viena Congresso Internacional História Musical por ocasião festas centenário Haydn ponto Isso não complicar com a sua ida Estocolmo estimaria fosse representar Brasil ou preparasse breve mas substancial notícia história música Brasil para ser submetida Congresso tomando por base pequeno artigo Prado página 62 tiragem parte Brasil Grande Enciclopédia e outras publicação sobre Nunes Garcia e Francisco Manuel e Carlos Gomes ponto Precisando algumas dessas publicadores podemos remete-las ponto Aguardo telegrama.

Rio Branco ${ }^{161}$
\end{abstract}

Desta vez o Barão do Rio Branco não somente convoca Oliveira Lima a representar o Brasil em mais um congresso como também emite ordens expressas sobre o conteúdo da conferência. Isto revela um profundidade maior do que observamos até aqui em termos dos envolvimentos do Barão nos sentidos da política externa executada por Lima em seu posto europeu.

Entretanto, este envolvimento não contradiz - ao contrário - somente confirma aquilo que vemos pensado em termos das aproximação entre o Rio Branco e Oliveira Lima, sobretudo no sentido de suas visões sobre as ligações históricas entre a nacionalidade brasileira e a tradição européia e o sentido de manutenção das relações e aproximações entre o Brasil e a Europa nos termos da política externa brasileira.

Em seu discurso no Congresso Internacional de História Musical de Viena, Oliveira Lima cumpre aos desígnios do Barão: inicia por citar a importância do padre José Maurício Nunes Garcia na história da música brasileira e trata de fazer conexões com Hyden, o homenageado do Congresso.

\footnotetext{
O espírito musical desenvolvera-se aliás suficientemente na colônia americana de Portugal que para o famoso Marcos Portugal, mestre de capela do rei, membro do instituto de França e compositor cujas óperas se representavam com grande êxito em todos os palcos italianos da época, ali pudesse encontrar, no Rio de Janeiro - onde a corte de Lisboa se viera estabelecer em 1908, por ocasião da invasão da Península pelas tropas napoleônicas - um digno êmulo. Chamava-se esse José Maurício Nunes Garcia, era padre e nascera no Brasil: sua música sacra, procedente dos grandes mestres alemães é, porém, de uma altíssima inspiração e de uma realização verdadeiramente notável.

Foi precisamente uma das maravilhosas sonatas de Haydn - o extraordinário artista cujo centenário celebramos por meio deste Congresso Internacional de Música, e a quem seu contemporâneo brasileiro colocava acima de Haendel e de Mozart e a par
}

${ }^{161}$ Telegrama datado de 11.03.1909 - Pasta de Telegramas da Legação em Bruxelas, Arquivo Histórico M.R.E. 
de Bach - o primeiro trecho diante da real família de Bragança e na presença do célebre "maestro Portogallo". ${ }^{162}$

Lima prossegue seu discurso citando relevância de mais dois músicos elencados pelo Barão: Francisco Manuel e Carlos Gomes:

\begin{abstract}
A segunda fase da música no Brasil, uma vez entrada no caminho de organização consciente, foi contemporânea da Independência, detonando bem o abalo causado por tal acontecimento político e podendo portanto denominar-se patriótica. É seu corifeu Francisco Manuel da Silva (1795-1865), discípulo dos mestres que o precederam, inclusive Neukonm, e autor do belíssimo hino nacional brasileiro, um dos mais entusiásticos e vibrantes que existem. Foi ele o fundador na capital do Brasil do Conservatório de Música, do qual um dos discípulos, nosso grande compositor Carlos Gomes (1839-1896), granjeou uma reputação mais do que nacional.

Carlos Gomes é especialmente apreciado na Itália, onde mereceu a consagração de Verdi e onde qual senão todas suas principais óperas - "O Guarany", "Fosca", "Salvador Rosas", "Schiavo" - foram primeiro cantadas e aplaudidas.

(...) Observa-se em todas as suas composições um calor comunicativo e uma exuberância de motivos, que só podem ser dons de um talento musical absolutamente de primeira ordem; mas ao mesmo tempo se nota um sentimento local, repousado sobre uma certa e indiscutível personalidade, que torna o artista particularmente querido dos seus compatriotas. ${ }^{163}$
\end{abstract}

Observem que o esforço de Lima nesta conferência vai primeiramente no sentido de dotar os músicos brasileiros de virtuosismo e reconhecimento musical. Trata também de evidenciar as conexões dos músicos brasileiros com a tradição européia, de modo a coloca-los sobre os mesmos padrões civilizacionais. Por fim, procura atribuir um certo um "patriotismo" ou um "sentimento local" a estes artistas, como que tentando caracterizar suas composições como brasileiras.

O diplomata voltaria a realizar uma Conferência a respeito de questões da formação histórica brasileira em 1910, num encontro da Real Sociedade Belga de Geografia, realizado no Théâtre Royal de la Monnaie de Bruxelas. e com a presença do Rei Leopoldo II. ${ }^{164}$

Inclusive, para esta Conferência fora convidado pelo próprio Rei a falar sobre questões da história e cultura do Brasil. Este movimento nos parece que demonstra com ainda mais força a ideia de que Oliveira Lima era visto ao mesmo tempo enquanto diplomata,

\footnotetext{
162 LIMA, Manuel de Oliveira. A música no Brasil do ponto de vista histórico. In: SOBRINHO, Barbosa Lima (Org.). Estudos Literários. Rio de Janeiro: Departamento de Imprensa Nacional, 1975.p.260.

${ }^{163}$ LIMA, Manuel de Oliveira. Op.Cit. In: SOBRINHO, Barbosa Lima (Org.). Estudos Literários. Rio de Janeiro: Departamento de Imprensa Nacional, 1975.p.261-262.

${ }^{164}$ SOBRINHO, Barbosa Lima (Org.). Op. Cit. p.95.
} 
representante do governo do Brasil na Bélgica e intelectual, Homem de Letras prestigiado e conhecedor dos aspectos da cultura brasileira.

Naquela ocasião falou sobre "La conquête du Brésil". Seu discurso foi no sentido de explorar a temática da configuração do território nacional, dando destaque ao que chamou de "conquista do Brasil pelos brasileiros".

(...) O que me propus expôr-vos esta noite - em resumo bem entendido, pois que o assumpto é largo - é de menos actualidade do que o seriam imaginárias cobiças estrangeiras. Desejaria dizer-vos alguma coisa sobre a conquista do Brazil pelos brazileiros, (...)

O Brazil teve pois de ser conquistado pelos seus habitantes, podemos dizer seus filhos. Esse território demarcado que hoje constitui um dos grandes paízes do mundo, juntamente com a China, os Estados Unidos e as Rússias, achava-se primitivamente defeso por tribus selvagens e pelas convenções diplomáticas, tão hostis umas quanto as outras. Não seria ilícito dar ao que passou o nome de conquista pacífica. Quanto mais não fosse, a isso se oporia a escravidão dos índios; mas podemos chama-la conquista civilizadora, apesar destas manchas que a moral do tempo era a primeira a attenuar. ${ }^{165}$

Notem que Oliveira Lima exalta a conquista e sua importância na configuração do território sob o argumento de um processo civilizador, em combate, na sua percepção, às hostilidades bárbaras das tribos indígenas originarias e às hostilidades das convenções diplomáticas - a saber, especificamente o Tratado de Tordesilhas - provavelmente vistas por Lima como favorável à Espanha.

Notem também que Lima cita e logo em seguida relativiza a violência com que os conquistadores tratavam os indígenas. Entendemos este movimento como um interessante exemplo das características do novo paradigma de produção historiográfica vinda com a República, paradigma este que explicamos no capítulo anterior. Vemos também como contradição no mais característica do momento de transição em termos de produção do conhecimento no qual Oliveira Lima estava inserido.

$\mathrm{Na}$ tentativa de escrever a História de maneira mais específica e complexa, Lima trata de destacar questões que anteriormente não seria tratadas, neste nosso caso a violência para com o indígena. Entretanto, neste movimento, logo se dá conta que sua citação entra de alguma forma em contradição com a sua interpretação de que teria sido uma conquista pacífica. Trata logo de justificar a questão dentro dos quadros da "conquista civilizadora" e da contextualização do que seria a moral naquele momento da conquista.

165 LIMA, Manuel de Oliveira. A conquista do Brazil. In: Revista do Instituto Histórico e Geográfico de São Paulo, Vol. XVII, 1912. 2a ed. p.6. 
$\mathrm{Na}$ realidade, para além de ressaltar a "conquista do Brasil pelos brasileiros", Oliveira Lima trata de dar relevância para a miscigenação entre o elemento português e indígena na formação histórica da nacionalidade brasileira.

\begin{abstract}
Foram essas expedições arrojadas que, na sua inconsciência heróica, conquistaram o Brazil. Uma raça - tomamos o termo no seu sentido mais vulgar e menos scientífico - formara-se pouco a pouco no sul, pelo cruzamento dos primeiros colonos com os indígenas, pois os negros só vieram mais tarde e foram sobretudo expedidos para os engenhos de assucar do norte. É a essa população especial e já nacional que é devida uma tal obra. Seu primeiro posto avançado foi São Paulo, a soberba cidade de agora, sobre o fresco e brumoso platô que coroa a serra de Cubatão. Alli vieram acampar missionários jesuítas e audaciosos colonos, os primeiros para se approximarem dos neophitos que almejavam fazer, os segundos para surprehenderem as minas com que sonhavam. Os bellos edifícios e os sumptuosos armazéns de hoje occupam o lugar das antigas choupanas que uma paliada teria insufficientemente protegido conta as violências dos selvagens, si a doce persuasão exercida pelos padres da Companhia se não houvesse empregado em domar sua resistência atemorizada. ${ }^{166}$
\end{abstract}

Notem que para além de ressaltar a miscigenação do português com o indígena na configuração dos paulistas, o trecho acima é quase uma exaltação à São Paulo. É também um exemplo importante da visão de Oliveira Lima sobre os padres jesuítas, tidos como mais um dos agentes civilizadores no Novo Mundo ao "domar" as "violências dos selvagens" com sua “doce persuasão". Vamos a mais um trecho.

Deste primitivo arraial prosseguiu a exploração, não systemática, pois que não podia
obedecer a um plano traçado de antemão, mas contínua, progressiva e até certo
ponto methodica, do sertão, como na nossa língua portugueza são chamadas, de um
modo geral, as terras além de uma larga zona do litoral. (...)
A tela de um pintor paulista, collocada no museu do Ipiranga, evoca com poderoso
relevo a lembrança das bandeiras, nome dado a tais expedições, grupadas em redor
de um chefe, verdadeiro "condotiere", e que na melhor quadra do anno, quando a
monção as favorecia, se punham regularmente em marcha. ${ }^{167}$

$\mathrm{Na}$ realidade, vemos que neste discurso Oliveira Lima trata de destaca o papel desempenhado pelos bandeirantes paulistas na "conquista do Brasil" e a importância deste movimento dentro dos quadros de expansão e conformação do território nacional brasileiro.

Desta vez o discurso foi publicado no Brasil na Revista do IHGSP, no ano de 1912. Não sabemos se foi Lima quem procurou o Instituto para a publicação ou se o movimento foi o contrário, mas nos parece que temática bandeirante pode ter influenciado nesta

\footnotetext{
${ }^{166}$ LIMA, Manuel de Oliveira. Op.Cit. In: Revista do Instituto Histórico e Geográfico de São Paulo, Vol. XVII, 1912. 2a ed. p.7.

${ }^{167}$ LIMA, Manuel de Oliveira. Op.Cit. In: Revista do Instituto Histórico e Geográfico de São Paulo, Vol. XVII, 1912. 2a ed. p.8.
} 
aproximação. De qualquer modo, vemos que este é um exemplo interessante da interlocução e presença de Lima em uma instituição produtora de conhecimento regional que ganha força a partir do novo paradigma da produção historiográfico.

Interessante também é notar como Oliveira Lima se corresponde com grande frequência com São Paulo, seja via o jornal O Estado de São Paulo, seja via IHGSP. Lembremos que naquela cidade conseguiu apoio importante no seu processo de articulação por uma remoção diplomática para a Europa. Parece que continuar em contato com São Paulo e diante daquela sociedade estabelecer e aprimorar seu prestígio era importante para suas colocações enquanto Homem de Letras e diplomata.

Outra Conferência realizada por Lima a constar neste mesmo volume da Revista do IHGSP foi a pronunciada em encontro da Sociedade de Geografia da Antuérpia em 1910. Neste caso, não sabemos se Oliveira Lima foi designado pelo Itamaraty ou convidado a discursar pelos organizadores do encontro. De qualquer forma, nos parece que, neste momento, a representação oficial diplomática e a figura do intelectual já eram indissociáveis.

Naquela ocasião pronunciou discurso sobre "Le Brésil et les étrangers", onde procurou dar exemplos, a seu ver, de valiosas contribuições de estrangeiros para a formação da nacionalidade brasileira. Novamente Lima reforça a ideia do Brasil enquanto "Civilização nos Trópicos”, desta vez destacando os esforços civilizadores de estrangeiros no Brasil.

Um primeiro exemplo vêm da ocupação holandesa no Brasil e, em especial, da exaltação a Maurício de Nassau.

A ocupação hollandesa trouxe ao Brazil, como governador geral a soldo da Companhia das Índias Occidentais um príncipe da casa de Orange, o conde João Maurício de Nassau Stegen; espírito aberto, esclarecido e dotado de sympathias (...) que merece ser contado entre os mais ilustres administradores do Novo Mundo. (...)

Maurício de Nassau, que era ao mesmo tempo um guerreiro, um epicurista e um letrado. Fez-se acompanhar ao Brazil por sábios, artistas e escrpitores, cujas chronicas em prosa e verso imortalizaram seus feitos; cujas pinturas que hoje se encontram desde o palácio real de Hampton Court, na Inglaterra, até o castelo real de Frederksborg, na Dinamarca, passando pelo Real Bibliotheca de Berlim, revelaram à Europa toda uma nova natureza, com suas paisagens exóticas, seus animaes extranhos, suas plantas desconhecidas e suas gentes selvagens; cujos livros e tratados estabeleceram a base dos estudos scientíficos na América. ${ }^{168}$

${ }^{168}$ LIMA, Manuel de Oliveira. O Brazil e os extrangeiros. In: Revista do Instituto Histórico e Geográfico de São Paulo, Vol. XVII, 1912. 2a ed. p.27. 
Vemos que além de destacar algumas "vitudes" de Nassau, Oliveira Lima trata de ressaltar alguns de seus "feitos" no sentido de revelar à Europa os "trópicos exóticos", e de estabelecer no Brasil as bases artísticas e científicas nos padrões da civilização européia.

Anda neste discurso se destaca também a vinda da Missão Francesa e o estabelecimento da Escola de Bellas Artes, agora já sob iniciativa de Dom João VI, reinando no Brasil.

\begin{abstract}
O concurso europeu nessa época assumiu mesmo a forma de uma colónia de artistas de valor, contratados em Pariz para fundarem nossa Escola de Bellas Artes e educarem o gosto nacional, dando-lhes um cunho superior. Tinha este grupo de instructores artísticos o secretário perpétuo da Academia de Bellas Artes de Pariz, Lebreton (...). O desenvolvimento das artes no Brazil é devedor a esses professores de pintura, de escultura, de architetura e de gravura, de um impulso que ainda dura e que naturalmente recebeu desde logo a contribuição das vocações nacionaes educadas em tal tradição adquirida. ${ }^{169}$
\end{abstract}

Vê-se que a nacionalidade dos estrangeiros é outra, assim como também é outro o motivo de suas vindas e o período da história nacional relatado. Mas o sentido civilizador permanece o mesmo. São os padrões da tradição europeia que vêem ao Brasil cumprir sua missão civilizadora.

Enfim, estas Conferências pronunciadas por Oliveira Lima entre 1908 e 1910 em congressos e encontros marcam uma primeira atividade de divulgação do Brasil no exterior. Observemos, por fim, que apesar de terem se dado em capitais periféricas da Europa, e por isto talvez serem menos prestigiosas do que as que veremos nas próximas fases, esta primeira fase acumulou a atividade mais numerosa e intensa de Lima em sua divulgação do Brasil.

Trataremos agora de um conjunto de Conferências que achamos por bem separar do conjunto das anteriores. Esta nossa escolha se deve ao fato de considerarmos elas mais relevantes que as demais, a começar pelo fato de terem sido pronunciadas na Universidade de Sorbonne, em Paris.

Entendemos que este é o momento de auge das divulgação empreendida por Lima. Após uma primeira fase de algumas Conferências em cidades e capitais mais periféricas da Europa, entendemos que Oliveira Lima havia adquirido fama e prestígio enquanto conferencista de questões da história e da cultura do Brasil diante dos Homens de Letras europeus. Esta sua fama e prestígio era tal que mesmo sendo representante oficial do Brasil

\footnotetext{
${ }^{169}$ LIMA, Manuel de Oliveira. Op.Cit. In: Revista do Instituto Histórico e Geográfico de São Paulo, Vol. XVII,
} 1912. 2 a ed. p.31. 
em Bruxelas, Bélgica, fora finalmente convidado a pronunciar na mais importante capital cultural europeia à época: Paris.

Em 1909 o diplomata é convidado a participar de um evento organizado pela Sociedade de Estudos Portugueses de Paris no Anfiteatro Richelieu da Universidade de Sorbonne. Tratava-se da Festa da Intelectualidade Brasileira, presidida por Anatole France, em celebração à efeméride de um ano de Machado de Assis, grande homenageado do evento.

Oliveira Lima participou da celebração proferindo a Conferência "Machado de Assis et son ouve littéraire", na qual, segundo a interpretação de Arnoni Prado, coloca Machado de Assis enquanto representante máximo das letras brasileiras, elegendo-o como figura principal de uma espécie de "Panteão Nacional das Letras". ${ }^{170}$

Tal Panteão seria construído por Lima a partir de critérios da tradição européia. O autor mereceria adentrar a este Panteão uma vez que fosse exemplo no Brasil da tradição europeia, por via latina e lusitana, como se fosse um discípulo dos clássicos portugueses a quem havia se igualado. Novamente, a idéia de continuidade, como se o autor no Panteão se configurasse em um elo de ligação, em um espaço comum que conecta o Brasil à Europa. Observemos, a seguir, alguns trechos desta conferência:

\footnotetext{
Machado de Assis, se bem que poeta, era outra coisa. Tinha-se libertado dos liames mais estreitos do nacionalismo, que frequentes vezes toca no nativismo e também invade os versos, e eleva-se a uma concepção mais geral, digamos o termo, humana da vida, sem por isso deixar de ser essencialmente nacional. Nos caracteres que desenhou não aspirou talvez a tanto; mas o fato é que eles se tornaram sintéticos sob o seu lápis, o que é o melhor meio de chegarem a universais. Nos seus contos e nos seus romances é o enredo curto e fácil, para não dizer esguio e pálido. Esta falta de vigor da contextura aparecia porém no seu caso, não tanto um artifício, como um atrativo, visto primar ele em envolve-la toda com a túnica sedosa da sua filosofia discreta e recobri-la com o manto de corte elegante do seu estilo límpido e impecável.

Reparo que acabo de mencionar, sem querer, as qualidades primordiais deste escritor, que seria notável em qualquer literatura e que muito assimilara das literaturas estrangeiras, de Sterne a Renan e de Heine a Anatole France. Tais qualidades são a agilidade na composição, a medida na ironia, a harmonia no conjunto. Com semelhantes dotes, combinados segundo uma receita de que ele possuía o segredo, fez-se inimitável, posto que provocando numerosos imitadores, prova certa e até indiscutível de superioridade. Não degenerou ele próprio a imitador, apesar de seu estudo aprofundado dos modelos. ${ }^{171}$
}

\footnotetext{
170 PRADO, Antonio Arnoni. Op. Cit., 2015. p. 76-81.

${ }^{171}$ LIMA, Manuel de Oliveira. Machado de Assis e sua obra literária. In: SOBRINHO, Barbosa Lima (Org.). Estudos Literários. Rio de Janeiro: Departamento de Imprensa Nacional, 1975.p. 38-39.
} 
Notem que Oliveira Lima inicia por exaltar algumas características da obra e da escrita de Machado de Assis e logo se põe a comparar, ou melhor, a praticamente colocar no mesmo hall de nomes relevantes da "literatura estrangeira". Este é, em linhas gerais, o movimento de Lima no decorrer de todo o seu discurso. Vejamos outro parágrafo.

\begin{abstract}
Dir-se-ia, e com razão, diante da reserva com que são desenhados todos os seus caracteres femininos, respeitáveis quase sem exceção, e a julgar também pelo conjunto da sua obra, de um humorismo sem grosseria como sem maldade, que Machado de Assis viveu muito na intimidade intelectual dos escritores ingleses. De fato, segundo há sido frequentemente notado, tinha ele um fraco pelos humoristas britânicos do século XVIII, Sterne, Fielding e Swift, e bem assim pelos romancistas do século XIX, Dickens, Eliot e Thackeray. Admirava muito Shakespeare, considerando-o uma árvore colossal e frondosa, de florescência maravilhosa, tipo de força e de beleza; mas era de preferencia àqueles outros que iam suas melhores simpatias, porquanto ressentia todo o seu enternecimento diante da vida, aliás buscando, como eles, esconder tal sentimento sob a máscara de uma ironia sempre alerta, mas nunca cruel. O seu sarcasmo, ainda que tenha sido diversamente tratado como uma manifestação amarga, era antes da natureza do atribuído a um dos personagens do seu primeiro romance: "benévolo e anódino, sabendo misturar os espinhos com rosas". ${ }^{172}$
\end{abstract}

Se no primeiro trecho Oliveira Lima realça as ligações de Machado de Assis com autores de diferentes Nações europeias, neste segundo trecho dá destaque para os autores britânicos. Entendemos que esse movimento vem no sentido de conectar Assis a diferente tradições literárias europeias, de modo a colocar o autor ao mesmo tempo como herdeiro destas tradição e de validade universal. Afinal, Machado de Assis era o grande destaque de seu "Panteão".

Vale agora notar o artigo A Festa da Sorbonne, escrita por Oliveira Lima e publicado no dia 6 de junho de 1909, mais uma vez no jornal O Estado de São Paulo. ${ }^{173}$ Neste artigo, Oliveira Lima procura deixar seus interlocutores brasileiros a par do discurso proferido por Anatole France quando da abertura dos trabalhos da Festa da Intelectualidade Brasileira.

$\mathrm{Na}$ interpretação de Lima, em seu pronunciamento Anatole France realiza uma exaltação do "Gênio Latino", representado ali na figura de Machado de Assis. É como se France concordasse com Lima que Machado de Assim pertence a uma categoria superior de autores, consagrada dentro dos padrões da tradição europeia. Mais do que isso, no artigo

\footnotetext{
172 LIMA, Manuel de Oliveira. Op.Cit. In: SOBRINHO, Barbosa Lima (Org.). Estudos Literários. Rio de Janeiro: Departamento de Imprensa Nacional, 1975.p.49.

${ }^{173}$ LIMA, Manuel de Oliveira. A Festa da Sorbonne. In: SOBRINHO, Barbosa Lima (Org.). Estudos Literários.
} Rio de Janeiro: Departamento de Imprensa Nacional, 1975. p. 62-66. 
Oliveira Lima expressa sua alegria em ver o reconhecimento de Machado de Assis enquanto um "elo de junção dos dois mundos intelectuais latinos, o Velho e o Novo".

Ainda nesta segunda fase, merecem também destaque as Conferências realizada em 1911 na mesma Universidade de Sorbonne, a convite do Groupement des Universités et des Grandes Écoles de France pour les rapports avec l’Amerique Latine.

O Groupement era um órgão oficial do governo francês, subordinado ao mesmo tempo ao Quay d'Ossay - Ministère des Affaires étrangères - e ao Ministère de l'Éducation nationale, cuja função era coordenar as aproximações entre as instituições educacionais francesas, Liceus e Universidades, com as Nações latino americanas. Tratava-se ao mesmo tempo de política educacional e política externa francesa, tendo como foco o aprimoramento dos relacionamentos e a garantia de influência cultural francesa na América Latina. A política ganha sentido dentro dos quadros do avanço dos imperialismos europeus e era vista como estratégica pela França, sobretudo em suas disputas com a Alemanha, praticante de política semelhante. ${ }^{174}$

A conexão entre o Groupement e Oliveira Lima se deu por meio da União FrancoPaulista, organização fundada por membros do Groupement em conjunto com intelectuais paulistas, alguns deles membros do IHGSP. Daí se nota elemento interessante que ainda não havíamos explicitado: com sua ida a Europa e a realização das Conferências, Oliveira Lima amplia sua rede de sociabilidade intelectual e passa a circular em redes internacionais, mais complexas e interconectadas.

Estas Conferências de 1911 na Sorbonne se organizaram na forma de um curso proferido por Oliveira Lima sob o título de Formation Historique de la Nationalité Brésilienne. Seu público era composto basicamente por intelectuais, sobretudo professores membros do Groupement e interessados em se aprofundar em questões da História do Brasil.

O curso de certa maneira sintetiza a visão de Oliveira Lima a respeito da formação histórica brasileira, dando destaque para as continuidades com relação à tradição portuguesa. Trata-se, na realidade de um resumo de suas principais obras historiográficas.

Além de explorar aquelas mesmas questões sobre o papel dos jesuítas e dos bandeirantes na formação nacional brasileira, conforme vimos em suas conferências da primeira fase, Lima apresenta reflexões sobre a importância dos Bragança nas continuidades

\footnotetext{
${ }^{174}$ CHRLE, Chistophe. Ambassadeurs ou Chercheurs? Les relations internationales des professeurs de la Sorbonne sous la III République. In: Dossier, volume 14, janeiro de 1994. p.42-62.
} 
do Brasil com relação a Portugal. Esta questão havia começado a ser explorada por Lima sobretudo - mas não somente - em sua recente obra Dom João VI no Brasil. Traz também algumas reflexões que viriam a aparecer com maior profundidade em $O$ Movimento da Independência e O Império Brasileiro, obras que completam a trilogia central sobre a narrativa da nacionalidade brasileira de Oliveira Lima, segundo - e estamos de acordo Vellozo.

No mesmo ano de 1911 as Conferências pronunciadas no curso seriam publicadas, em francês, pela editora Garnier em livro sob o título homônimo e ganhariam circulação na Europa. Viria a ser publicada no Brasil somente em 1944, quando Oliveira Lima não estava mais em vida. Talvez não fizesse sentido sua publicação anterior pelo fato de seus interlocutores brasileiros já terem bastante acesso às reflexões de Lima sobre a questão, sobretudo com as publicações no jornal O Estado de São Paulo e com a grande penetração de Dom João VI no Brasil.

\subsection{2 - Revue}

Ainda em 1909, após a participação de Oliveira Lima na Festa da Intelectualidade Brasileira em Sorbonne. Sua conferência Machado de Assis et son ouve littéraire parece ter causado boas impressões e Oliveira Lima é convidado a escrever para a revista francesa $L a$ Revue uma série de artigos, nos mesmo moldes daquele sobre Machado de Assis, mas agora sobre diversos "Escritores Brasileiros Contemporâneos".

O convite partiu do redator do periódico Jean Finot - um polonês naturalizado francês, - cuja linha editorial procurava reforçar um "sentimento de solidariedade internacional" a partir da difusão de uma "visão mundial dos acontecimentos". A idéia era que na Revue figurassem noticiários e artigos que informassem o leitor francês sobre questões da cultura de diversos Nações das mais diversas parte do Mundo.

Quando do início da série, a Revue - na figura de Jean Finot - publicou uma nota num sentido bastante próximo daquele pronunciamento de Anatole France na Festa da Intelectualidade Brasileira. Finot ressalta os laços de fraternidade entre os latinos e chama a 
atenção do público francês para o fato de que o Brasil deveria ser melhor conhecido na França, uma vez que é importante Nação pertencente à tradição latina. ${ }^{175}$

Na série da artigos para La Revue - série esta que se estende até o meados de 1910 Oliveira Lima inicia por transcrever na íntegra sua conferência sobre Machado de Assis. Prossegue enquanto crítico literário de autores como Colho Neto, José Veríssimo, Olavo Bilac, Rui Barbosa e Joaquim Nabuco. Cada um em sua particularidade, os autores são todos eleitos por Oliveira Lima para aquele mesmo "Panteão Nacional das Letras". Nos parece que Lima entende que de alguma maneira este autores também se adequam aos critérios de legitimação das obras a partir de suas vinculações com as tradições europeias. ${ }^{176}$

Vamos dar exemplos da continuidade dessa concepção com trechos desses artigos, acompanhando algumas considerações que Oliveira Lima faz sobre cada um desses autores. Acompanharemos a ordem das publicações e iniciaremos por Coelho Neto.

O Sr. Coelho Neto preza particularmente o macabro, e a sua imaginação ali atinge as proporções que bem se podem imaginar. Há, na sua obra, visões de remorso que fazem empalidecer pela exuberância da sua angustia a descrição clássica de Dostoievsky, no "Crime e Castigo". Em tais ocasiões sua linguagem empenha-se, sob uma avalanche de termos vulgares ou raros, em fazer servirem o efeito alvejado pela sua arte todas as tintas das frias auroras bem como todos os rumores das noites borrascosas. Cavalos galopam, bois mugem, rãs coaxam, árvores despedaçam-se: é toda a gama de uma natureza animada e palpitante, como o estilo do escritor, que a pulsação de vida apenas impede de tornar-se retórico no sentido pejorativo do termo. ${ }^{177}$

Vemos aí a referencia a Dostoievsky e seu "Crime e Castigo". Parece até que, neste caso específico, Oliveira Lima enxerga certa superioridade na escrita de Coelho Neto em comparação ao autor russo. Razão mais que suficiente para ingressar em seu "Panteão". Vamos prosseguir, agora com as apreciações sobre José Veríssimo.

Deve ainda ser mencionado no seu ativo de escritor que dirigiu superiormente, durante alguns anos, a "Revista Brasileira" e que soube mantê-la sempre num alto novel, o que não é vulgar num país novo e de produção literária muito desigual. Neste momento prepara o Sr. José Veríssimo uma história de conjunto da literatura nacional, para a qual se acha melhor documentado do que ninguém, e que segundamente abundará em postos de vista originais e pessoais (...).

${ }^{175}$ SOBRINHO, Barbosa Lima (Org.). Estudos Literários. Rio de Janeiro: Departamento de Imprensa Nacional, 1975. p. 19-20.

176 PRADO, Antonio Arnoni. Op. Cit., 2015. p. 81-86.

177 LIMA, Manuel de Oliveira. Escritores Brasileiros Contemporâneos I: Coelho Neto. In: SOBRINHO, Barbosa Lima (Org.). Estudos Literários. Rio de Janeiro: Departamento de Imprensa Nacional, 1975.p.73-74. 


\begin{abstract}
(...)
Visto o escritor que é o Sr. José Veríssimo compenetrar-se da forma maus honesta das suas funções de crítico literário, era-lhe essencial principiar por definir de um modo satisfatório, para si próprio ao menos - que é literatura? E, em seguida útil saber como considera ela a crítica. "A crítica existe - escreve-, e tudo o que existe, pode-se afirmar sem fatalismo, tem uma razão de ser. Mas não só existe, como tem já hoje um corpo de doutrina, um conjunto, senão de regras, de princípios derivados do estudo, da meditação, da comparação das grandes obras do espírito humano no domínio da pura estética. A psicologia, a sociologia, a moral, como ciências do homem e da sociedade, ministram ao estudo de tais obras, e à crítica portanto, dados, explicasse, esclarecimentos, noções que acabaram por dar à crítica, mesmo no meio das variações dos critérios pessoais, um certo grau de positividade. Em todos os países, homens da mesma cultura avaliam da mesma maneira, com insignificantes diferenças, as produções artísticas ou literárias, antigas e modernas. (...)" 178
\end{abstract}

Notemos uma diferença na apreciação de Oliveira Lima sobre José Veríssimo com relação às outras críticas de escritores brasileiros que vimos até aqui. Desta vez, Lima não vai tanto no sentido de enaltecer particularidades de estilo ou da obra nem tece comparações com escritores estrangeiros. No caso de José Veríssimo trata de dar relevo à sua atuação como crítico literário.

Por sinal, Oliveira Lima começa mesmo por destacar a atuação de Veríssimo enquanto crítico literário à frete da Revista Brasileira, espécie de núcleo inicial em torno do qual se formou a $\mathrm{ABL}$, conforme vimos no capítulo anterior. Nos parece que aqui Lima trata de se corresponder diretamente com aquele que é o centro da consagração nacional das letras.

Mais do que isso, é interessante notar que Lima coloca explicitamente as referências de Veríssimo no que tange à sua atividade de crítico. Referências estas, a nosso ver, pautadas em um certo "Universalismo Europeu", se nos permitem parafrasear Walerstein. Vamos a mais um parágrafo de Lima sobre Veríssimo neste mesmo sentido.

A respeito de Sainte-Beuve, num ensaio que, como todos seus outros sobre escritores estrangeiros, fornece a medida da adaptação brasileira aos sentimentos das outras nacionalidade e às belezas das outras literaturas, deparam-se-nos ainda estas linhas sobre a missão da crítica, que, no século XIX, se teria distinguido por uma compreensão mais justa e mais equitativa do passado pela ausência de preconceitos anti-religiosos e políticos, por uma mais larga apreciação da constituição etnica e social dos povos, e, principalmente, pela introdução definitiva nela da noção positiva do relevo e da hipótese fecunda e indispensável da evolução: "Outro caráter da crítica do século XIX é a sua unidade final. Filosófica, científica, estética, literária, histórica, religiosa, social, toda ela não só derivada da mesma concepção, mas se apoia no mesmo conjunto de conhecimentos de que o século foi, nos diferentes domínios da erudição ou da ciência, o principal criador". ${ }^{179}$

${ }^{178}$ LIMA, Manuel de Oliveira. Escritores Brasileiros Contemporâneos II: José Veríssimo. In: SOBRINHO, Barbosa Lima (Org.). Estudos Literários. Rio de Janeiro: Departamento de Imprensa Nacional, 1975.p.78-80.

${ }^{179}$ LIMA, Manuel de Oliveira. Op.Cit.. In: SOBRINHO, Barbosa Lima (Org.). Estudos Literários. Rio de Janeiro: Departamento de Imprensa Nacional, 1975.p.80-81. 
Temos aí um relato revelador a corroborar com aquilo que já vínhamos ensaiando dizer. Parece que Veríssimo é o centro de consagração nacional das letras justamente por caber a ele, enquanto crítico literário, a operação de oferecer "a medida da adaptação brasileira aos sentimentos das outras nacionalidade e às belezas das outras literaturas". E esta medida da adaptação é possível exatamente pela presença de uma dada unidade critica, "fornecida pela introdução definitiva nela da noção positiva do relevo e da hipótese fecunda e indispensável da evolução”.

Dito de outro modo, em seu artigo Oliveira Lima coloca José Veríssimo como o representante no Brasil do modelo de crítica literária a ser seguido. Isto se dá pela sua capacidade de criticar os autores e obras nacionais, brasileiras, a partir de um modelo de crítica literária consagrado na tradição universal e civilizada, ou melhor na tradição européia.

No artigo sobre Olavo Bilac, Lima retorna ao modelo consagrado nas análises de Machado de Assis e Coelho Neto. O parágrafo inicial de seu artigo já é revelador da retomada dos elogios e das comparação entre os autores brasileiros e os da "tradição civilizada".

\begin{abstract}
A reputação de poeta do Sr. Olavo Bilac é muito grande e muito merecida. Se outros no Brasil possuem mais originalidade e mais sentimento, nenhum dos seus contemporâneos possui mais senso artístico nem mais vibração sensual. Como prosador ele é também digno de nota, mestre na crônica e primoroso nas conferências. Sua palavra é fluente, quente, colorida tanto quanto sua pena é viva, espirituosa e comovida. Seu estilo oratório assim como sua maneira jornalística distinguem-se contudo pelo bom gosto. O jornalismo ativo por ele exercido não é aliás precisamente político. Seu curto artigo quotidiano, sob o titulo geral de "Registro", no gênero em que sobressaiu Francis Magnard e que tanto se popularizou Hardonin, passa em revista os acontecimentos de preferência sociais que ocorrem dentro e fora do pais, ou mais modestamente comenta o fato diário que mais feriu sua atenção. ${ }^{180}$
\end{abstract}

Sobre Olavo Bilac, Lima parece querer enfatizar a completude enquanto Homem de Letras, atuante nos mais diversos gêneros literários e até na atividade jornalística, fato muito comum à época, como sabemos. Um Homem de Letras completo, que se enquadra no modelo consagrador e que se destaca diante de seus pares merece também adentar ao "Panteão".

Se até este momento Oliveira Lima vinha criticado - e consagrando - Homens de Letras mais próximos ao universo literário propriamente dito, agora parte para a apreciação de nomes atuantes também nas atividades políticas. Vamos ao primeiro deles, Rui Barbosa:

\footnotetext{
${ }^{180}$ LIMA, Manuel de Oliveira. Escritores Brasileiros Contemporâneos III: Olavo Bilac. In: SOBRINHO, Barbosa Lima (Org.). Estudos Literários. Rio de Janeiro: Departamento de Imprensa Nacional, 1975.p.83.
} 
Todos os aspectos sob os quais se revela o poderoso espirito do Sr Rui Barbosa podem fundir-se num só: é um extraordinário agitador de idéias, talhado para a luta como nenhum outro, visto ninguém o igualar em seu país em labor mental e na surpreendente assimilação de uma leitura assídua, variada, prodigiosa, insaciável. Sua erudição é de fato espantosa e inesgotável sua fecundidade literária, posto que assaz contida para se não tornar vulgar ou apressada. A prontidão de sua inteligência faz com que na última conferencia de Haia começasse esta assembléia por experimentar uma surpresa e acabasse maravilhada.

(...)

Se o Sr. Rui Barbosa possui como escritor um defeito, é o de não ser conciso. Seu cérebro tem demasia substância para que pudesse ser de outro modo. Equivaleria a exigir de Balzac o ser sóbrio nas suas narrações ou de Vitor Hugo o ser continente nas suas metáforas. O Sr. Rui Barbosa parece sempre querer esgotar seu assunto, e suas qualidades de estilista são tais - a opulência lexicográfica, a seleção justa dos vocábulos, os torneios de frase inesperados, a abundância das imagens, a audácia e o imprevisto da construção - que a sedução da sua maneira literária nada sofre com isso, e que o valor dos seus pensamentos não é minguado pela extensão concedida à sua manifestação detalhada. ${ }^{181}$

Observem que Oliveira Lima inicia por exaltar Rui Barbosa em suas características cuja apreciação maior talvez se desse na esfera das atividades políticas. Mas mesmo ao fazer isto, não deixa de notar o que seria de se exaltar em qualquer Homem de Letras. Em seguida, parte logo para o elogio de suas virtudes literárias e trata novamente de estabelecer conexões com os literatos europeus.

Ou seja, mesmo tratando de um intelectual talvez mais reconhecido por sua atuação na esfera política - seja no Senado, seja como Ministro ou até mesmo em sua atuação como delegado do Brasil na Conferência de Haia - Oliveira Lima não deixa de ver Rui Barbosa a partir dos mesmos critérios críticos que já vinha adotando. Mais do que isso, notem que Lima não deixa de ver Rui Barbosa como um Homem de Letras, pertencente ao mesmo tempo da esfera política e da esfera cultural.

O último Homem de Letras que observaremos na apreciação crítica de Oliveira Lima é Joaquim Nabuco:

Joaquim Nabuco, falecido há poucos meses em Washington, onde exercia as funções de Embaixador do Brasil, era o mais elegante ao mesmo tempo que o menos nacional dos escritores do seu país, (...).

(...) o escritor conservava, no seu meio natal, um gosto e uma consciência - bem entendido, literários - estranhos a este meio, e tal gosto bem como tal consciência tinham mesmo sofrido diferentes metamorfoses, todas vindas de fora. Representam sucessivamente semelhante ação a orientação inglesa, quer dizer saxônica; em seguida a francesa, depois a romana, ambas, portanto, latinas, antes de retornar à orientação saxônica na sua modalidade americana. (...)

${ }^{181}$ LIMA, Manuel de Oliveira. Escritores Brasileiros Contemporâneos IV: Rui Barbosa. In: SOBRINHO, Barbosa Lima (Org.). Estudos Literários. Rio de Janeiro: Departamento de Imprensa Nacional, 1975.p.90-92. 


\begin{abstract}
(...)
Depressa se percebe quanto é pessoal a obra literária de Joaquim Nabuco: esse é mesmo um de seus traços característicos. (...)

Não são memórias, não é uma autobiografia: sim a notação das influências que se exerceram sobre seu espírito e o modelaram, a história - o termo empregado é exato - da sua formação moral. Vê-se perfeitamente por aí que um americano possa ter a alma européia e também que, sob as influências estrangeiras operando sobre seu espírito, se possam enxergar suas impressões de infância regulando e dirigindo o coração. (...)

(...)

A influência, quer francesa, quer inglesa, foi das mais benéficas sobre o escritor e orador. Essa dupla influência afinou cedo seus grandes dotes naturais e ensinou-o a não se afastar da moderação, do tato, do bom gosto, da distinção, predicados de que instintivamente ele se aproximava. Tornou-se assim um dos intelectuais mais complexos do seu país, o mais perfeito mesmo do ponto de vista da elegância sóbria do seu estilo e, senão da riqueza, pelo menos da justeza do seu pensamento. ${ }^{182}$
\end{abstract}

Entendemos o artigo de Oliveira Lima sobre Joaquim Nabuco de uma maneira um pouco diferente da que vínhamos lendo até o momento. Um primeiro ponto a observar é a frase inicial do artigo: seu colega de carreira havia falecido a poucos meses. Lembremos que Lima e Nabuco eram bastante próximos no início da trajetória intelectual de Lima e depois, em razão de divergência de opinião a respeito das tendências políticas de aproximação diplomática com os Estados Unidos, havia rompido a amizade. O leitor deve se lembrar que vimos esta questão no capítulo anterior e atribuímos a ela mais uma das "incontinências na pena" por parte de Oliveira Lima.

O fato é que a amizade entre os dois não havia sido reestabelecida e Lima se via agora diante de uma situação delicada do ponto de vista emocional. Ao observarmos o artigo, podemos perceber que Lima ainda admirava seu colega, e talvez desejasse mesmo reestabelecer os laços de amizade. Sendo isto impossível do ponto de vista material, nos parece que Lima tenta fazê-lo numa homenagem póstuma a Nabuco.

Entendemos que o reestabelecimento dos laços se dá ao Lima colocar também Nabuco no seu "Panteão". Entretanto, desta vez o critério critico, apesar de parecido, é um pouco diferente do adotado para os outros escritores. Nos demais Homens de Letras aparecia Oliveira Lima mostrava aqui ou ali, na obra ou na característica da escrita, alguma semelhança com algum autor europeu que pudesse ser digna de nota e de reconhecimento. Entretanto nota Lima que a obra literária de Nabuco é muito pessoal, ela mesma a "história da sua formação moral", ou seja, uma espécie de descrição de suas influências. O próprio título de uma de das principais obras de Nabuco evidencia esta peculiaridade: Minha Formação.

\footnotetext{
${ }^{182}$ LIMA, Manuel de Oliveira. Escritores Brasileiros Contemporâneos VII: Joaquim Nabuco. In: SOBRINHO, Barbosa Lima (Org.). Estudos Literários. Rio de Janeiro: Departamento de Imprensa Nacional, 1975.p.120-127.
} 
Por conta desta característica, Lima não faz a apreciação crítica da obra ou da escrita de Nabuco, faz a apreciação crítica de seu "espírito", de sua "alma”, ou melhor, do próprio Nabuco. O critério critico de Lima permanece porém, o mesmo: é a partir da tradição europeia. Mas se a própria influencia formadora, a própria "alma" de Nabuco era européia, a apreciação não podia ser outra senão a exaltação de Nabuco como modelo de Homem de Letras, e dos mais notáveis e imbuído das qualidades mais "civilizadas". Encerramos assim aqui as análises mais detalhas dos artigos de Lima sobre os escritores brasileiros.

Entretanto, cabe ainda notar que vemos a estratégia de Lima em criar conexões entre os escritores - ou Homens de Letras, de uma maneira mais geral - brasileiros e europeus a partir de uma perspectiva complexa. Vemos que é uma maneira de Lima fazer seus leitores no Velho Mundo compreenderem, a partir de critérios e autores por eles conhecidos, as obras e características dos escritores brasileiro. É, ao mesmo tempo, uma concepção literária e historiográfica de Lima, uma crítica a partir dos critérios da tradição européia e a demonstração de sua continuidade no Brasil, como no mais vínhamos destacando ao longo de nossa análise. Mas é também um recurso politico, em mais uma política cultural externa empreendida por Oliveira Lima, naquele mesmo sentido de buscar aproximações nas relações do Brasil com as Nações européias.

Vale também ressaltar o fato de estes autores todos serem pares de Oliveira Lima na ABL. Ao realizar a crítica literária de seus confrades acadêmicos Lima acaba por divulgar suas obras para a Europa, sobretudo para a França. Além disso, entendemos que Oliveira Lima talvez tivesse em mente o interesse em ganhar prestígio perante seus pares intelectuais no Brasil, uma vez que é ele quem lhes serve de conexão com a Europa.

A série de artigos sobre "Escritores Brasileiros Contemporâneos" deixa de circular na Revue em 1910 e segue até o ano de 1912 no Bulletin de la Bibliothèque Americane e na Revue d'Europe et Amérique. Nestas novas revistas, Lima escreve críticas literárias sobre a obra de Carlos Laet, Rodolfo Teófilo, Silvio Romero, Euclides da Cunha e Aluísio Azevedo. Os autores desta série apesar de não terem sido alçados por Oliveira Lima ao seu "Panteão" mereciam a apreciação de sua crítica, talvez ainda a partir da lógica do prestígio junto a sua rede de sociabilidade intelectual. Vale aqui ressaltar o fato de toda a série de artigos sobre “Escritores Brasileiros Contemporâneos" ter sido publicada no Brasil pelo jornal O Estado de São Paulo, o que vem ao encontro de nossa lógica. 
Por fim, vale citar outro trabalho de Oliveira Lima no sentido de sua atividade de divulgação do Brasil no exterior. Trata-se do prefácio de 1910 escrito pelo diplomata para a obra "Anthologie française des écrivains brésiliens" de Victor Orban - um estudioso e admirador das letras brasileiras - no sentido de divulgar a literatura do Brasil na Europa, projeto que vai evidentemente de encontro com as pretensões de Oliveira Lima apresentadas até aqui. A redação deste prefácio e as relações com Victor Orban de alguma maneira demonstra que Oliveira Lima se valeu das redes de sociabilidade intelectual internacionais como meio para que se viabilize seu projeto de divulgação do Brasil no exterior.

\section{2 - O sentido da divulgação}

Neste espaço queremos propor uma reflexão final sobre o sentido da divulgação do Brasil no exterior empreendida por Oliveira Lima entre 1908 e 1912, nosso objeto de estudo. Ou melhor, queremos propor um reflexão que seja capaz de articular as diversas questões abordadas ao longo deste trabalho no entorno do nosso objeto.

Entendemos que o sentido da divulgação se dá na articulação com seu contexto intelectual, as redes de sociabilidade intelectual, as pautas das instituições políticas e produtoras de conhecimento e a posição defendida por Oliveira Lima na questão da constituição da nacionalidade.

Para tal, vamos inicialmente problematizar a visão de alguns autores sobre o objeto de nosso estudo para depois colocar a nossa visão pela reflexão do sentido da divulgação para o Oliveira Lima enquanto homem de letras e enquanto diplomata. Ao longo da análise buscaremos articular todas estas questões em sua atuação entre a historiografia, a critica literária e a política externa brasileira.

\subsection{1 - O que se diz sobre o sentido da divulgação}

Recuperando o que já dissemos na introdução deste trabalho, o estudo da diplomata Maria Theresa Forster, Oliveira Lima e as relações exteriores do Brasil: o legado de um pioneiro e sua relevância atual para a diplomacia brasileira, em seu esforço de buscar destacar e recuperar a importância de Oliveira Lima para o Itamaraty acaba por classificar sua 
divulgação do Brasil no exterior como uma espécie de pioneirismo em "diplomacia cultural". 183

Apesar de irmos ao encontro de Forster em realçar a importância de Lima e de sua atividade dentro do âmbito do Itamaraty, procuramos ao longo deste trabalho relativizar a ideia de "pioneirismo" e de "diplomacia cultural" com nossa escolha metodológica em estudar o objeto a partir de concepções mais modernas e elaboradas em termos historiográficos, como por exemplo o "contextualismo linguístico" de Quentin Skinner ou então as reflexões metodológicas da "história das Relações Internacionais" a partir do paradigma francês.

Neste nosso processo de problematizar a questão nos deparamos com a obra Oliveira Lima e a construção da nacionalidade de Teresa Malatian. Apesar de a autora se valer de concepções metodológicas que consideramos mais adequadas ao estudo do objeto - como por exemplo as "redes de sociabilidade intelectual" de Sirinelli e as disputas por "capital simbólico" de Bourdieu -, Malatian acaba por apenas citar, em poucas frases, a divulgação:

\footnotetext{
Afinal (Oliveira Lima) consegui obter a nomeação para a Legação de Bruxelas, (...). Neste posto exerceu uma diplomacia de representação cultural mediante conferências, realizadas inclusive me universidades européias, e publicação de artigos na imprensa. ${ }^{184}$
}

$\mathrm{Na}$ realidade, Malatian apenas cita a questão para contextualizar o momento em que Oliveira Lima faz suas conferências na Sorbonne sobre a Formation Historique de la Nationalité Brésilienne, na visão da autora uma obra em que Oliveira Lima manifesta sinais de adesão e apoio à volta da Monarquia, questão que, como sabemos, foi um dos elementos a antecipar sua aposentadoria. Vemos, assim que a autora estava ali mais interessada em explorar as articulações que levaram ao fim da carreira diplomática de Lima do que à divulgação do Brasil no exterior. Temos, portanto, objetos de estudo diferentes, o que nos levou a continuar nos aprofundando na questão.

Por fim, na obra Um Dom Quixote gordo no deserto do esquecimento. Oliveira Lima e a construção de uma narrativa de nacionalidade de Júlio Vellozo, apesar de termos pontos de observação diferentes sobre a produção de Lima, nos deparamos com algumas reflexões mais elaboradas sobre a questão da divulgação do Brasil no exterior.

\footnotetext{
${ }^{183}$ FORSTER, Maria Thereza Diniz. Oliveira Lima e as Relações Exteriores do Brasil. Brasília: FUNAG, 2011. ${ }^{184}$ MALATIAN, Teresa. Oliveira Lima e a construção da nacionalidade. Bauru: EDUSC, 2001. p.227.
} 
Para Vellozo, naquele momento em que fora removido para seu posto em Bruxelas, Oliveira Lima optara por se dedicar cada vez mais à historiografia em detrimento da diplomacia. É como se Lima já tivesse alí, àquela altura, quase que desistido da carreira diplomática e "torcia para que o Barão o esquecesse na paz dos arquivos". ${ }^{185}$

Isto, na visão de Vellozo, muito por conta de seus desentendimentos com Rio Branco e Nabuco e tendo em vista o prestígio cada vez maior que Lima ganhava como historiador, sobretudo com a publicação de Dom João VI no Brasil.

Assim, as divulgações do Brasil no exterior são vistas por Vellozo como oportunidades que Lima tinha de expressar sua visão sobre a questão da nacionalidade brasileira para seus interlocutores no Brasil, nada tendo a ver com sua atividade diplomática.

Apesar de a reflexão de Vellozo ser mais aprofundada que a de Forster e Malatian sobre a questão da divulgação, concordamos apenas em parte com ela. Para nós, para além das disputas historiográficas em torno da questão da nacionalidade brasileira, a divulgação faz também sentido enquanto política externa. Foi isto que procuramos demonstrar ao longo de todo o trabalho.

Feita a revisão do que se diz sobre o sentido da divulgação do Brasil no exterior empreendida por Oliveira Lima, vamos enfim à nossa reflexão final.

\subsection{2 - Entre o Homem de Letras e o Diplomata}

$\mathrm{Na}$ introdução de nosso trabalho colocamos nossas hipóteses de estudo da seguinte maneira:

No início da pesquisa, o estudo tinha a hipótese de que trava-se de divulgar para a Europa, e sobretudo para Paris, modelo de civilização, aquilo que era culturalmente produzido no Brasil em termos dos mesmos padrões civilizacionais, de modo posicionar o Brasil enquanto país civilizado nos trópicos, estando ele portanto no mesmo patamar das demais nações civilizadas europeias.

Um outro ponto colocado no início da pesquisa buscava compreender se esta atividade se relacionava aos posicionamentos de Oliveira Lima diante das discussões intelectuais em

\footnotetext{
185 VELLOZO, Júlio Cesar de Oliveira. Um Dom Quixote gordo no deserto do esquecimento. Oliveira Lima e a construção de uma narrativa de nacionalidade. 2012. 219 p. Dissertação (Mestrado em Culturas e Identidades Brasileiras) - Instituto de Estudos Brasileiros, Universidade de São Paulo, São Paulo. p.73.
} 
torno da questão da nacionalidade brasileira ou a uma política externa brasileira defendida e executada pelo diplomata diante das questões da inserção do Brasil no Mundo. Com o decorrer dos estudos, passamos a entender que poderia se tratar de ambas as possibilidades, de maneira articulada. Assim, assumimos tal constatação como segunda hipótese do estudo.

Desta duas hipóteses iniciais, na medida em que o estudo avançava, derivaram-se reflexões mais complexas e intrincadas. Procuraremos expor a seguir os caminhos pelos quais esta reflexão se deu e procuraremos expor as conclusões deste trabalho.

Começamos por explorar os discursos tanto do ponto de vista de uma análise internalista (estudando alguns conceitos fundamentais internamente aos textos), quanto de uma análise externalista (o sentido dos textos em seu contexto). Ao mesmo tempo, tentávamos compreender qual era o sentido para o qual os discursos poderiam ser “instrumentalizados” por Oliveira Lima visando a atender às suas questões historiográficas e/ ou aos desígnios e concepções da política externa brasileira.

Entendemos que Oliveira Lima foi capaz de construir em torno de si a imagem de "Embaixador Cultural/Intelectual do Brasil" e os discursos faziam parte dos mecanismos pelos quais esta proposta foi se costurando. Mais do que isto, em sua atividade de divulgação Oliveira Lima se colocava ao mesmo tempo enquanto interlocutor e representante dos Homens de Letras do Brasil perante os "Homens de Letras civilizados" - os intelectuais da Europa - e interlocutor e representante oficial do Estado Nacional brasileiro perante as Nações européias.

Esta posição complexa garantiria a ele poder de articulação na sua rede de sociabilidade intelectual, estratégia fundamental para que Oliveira Lima alcançasse seu objetivo de ser removido enquanto Embaixador para um posto em alguma importante capital europeia, de preferência Londres. Isto lhe garantiria acesso privilegiado a importantes acervos históricos - essenciais para sua produção historiográfica - e significativa posição na condução da política externa brasileira.

Do ponto de vista dos interesses da política externa brasileira, o Barão do Rio Branco, chanceler à época, vinha com uma política de aproximação do Brasil com os Estados Unidos, ao mesmo tempo em que desejava manter os vínculos com a Europa. Nos corredores do Itamaraty, Joaquim Nabuco, primeiro Embaixador do Brasil em Washington, se posicionava enquanto aquele que articulava a aproximação com os Estados Unidos, enquanto que Oliveira 
Lima, Ministro Plenipotenciário do Brasil em Bruxelas (uma capital europeia de segunda categoria para os padrões diplomáticos), procurava no estabelecimento de sua posição e imagem enquanto "Embaixador Cultural/Intelectual do Brasil" o capital politico para alçar sua promoção a Embaixador do Brasil em Londres e ser, assim, o responsável pela manutenção das relações com a Europa. Como fica evidente, ao mesmo tempo em que Oliveira Lima se coloca enquanto diplomata a atender aos desígnios da política externa, busca também marcar sua posição na disputa intelectual pela definição da questão da nacionalidade brasileira.

O objetivo de alçar ao posto de Embaixador do Brasil em Londres, a estratégia de se posicionar enquanto "Embaixador Cultural/Intelectual do Brasil" para articular o posto e a tática de se valer dos discursos enquanto instrumento capaz de construir sua posição e imagem nas diversas disputas em que se envolveu é a conclusão mais complexa posta nesta reflexão deste estudo. A ela soma-se a constatação de que a "ideia de Brasil" enquanto “Civilização nos Trópicos" defendida por Oliveira Lima seria capaz de estabelecer aproximação com seus pares nas instituições e na sua rede de sociabilidade intelectual, ao mesmo tempo em que atende ao seu projeto de política externa brasileira ao estabelecer conexões e proximidades com a Europa.

\section{3 - O final do processo}

Se observarmos somente seu sucesso na divulgação do Brasil no exterior, poderíamos dizer que os acontecimentos iam na direção desejada por Lima. Seria questão de tempo para obter seu posto em Londres. Mas não seria Oliveira Lima se não se envolvesse em mais algumas polêmicas. Temo dizer, caro leitor, que dessa vez sua "incontinência na pena" seria fatal.

No início do ano de 1910 Oliveira Lima se envolveu decididamente com a Campanha Civilista. Tratava-se de articulação em apoio à candidatura de Rui Barbosa à Presidência da República em oposição ao candidato Hermes da Fonseca, um General do Exército apontado pelo então Presidente Nilo Peçanha. Nos interessa aqui saber que ao final do pleito a Campanha Civilista foi derrotada e o General Hermes ao assumir a Presidência optou por manter o Rio Branco como Chanceler. Se a situação de Lima nos corredores do Itamaraty ia melhorando em função de sua atividade de divulgação do Brasil, sua posição aberta em favor 
de Rui Barbosa acabaria por gerar certos desconfortos e enfraquecer novamente suas aspirações na carreira.

Outro aspecto a deteriorar a situação de Lima foram os boatos sobre sua simpatia ao regime monárquico. As conferência em Sorbonne sobre a Formation Historique de la Nationalité Brésilienne podem ter sido vistas, por seus pares no Brasil, como simpáticas à Monarquia, conforme já havíamos mencionado anteriormente a partir da visão de Malatian sobre a questão. Como se não bastasse, Lima conhecera e vinha se aproximando em Bruxelas a D. Luiz de Orleans e Bragança, herdeiro do trono em caso de restauração do regime. Escreveria, inclusive, artigos elogiosos à sua pessoa, o que somente aumentavam as incertezas quanto à lealdade de Lima para com o República que representava em Europa.

No inicio de 1912 o Barão do Rio Branco viria a falecer. Se Lima tivera desentendimentos com o Barão, ao menos compartilhavam posição de manutenção e aprofundamento das relações com a Europa. Esta nova situação, justamente com sua posição enfraquecida nos corredores do Itamaraty por conta de suas recentes polêmicas seria, agora sim, fatal para os entusiasmos de Lima para com a carreira. Veio em 1912 seu pedido de aposentadoria.

Enquanto não vinha a exoneração oficial, Oliveira Lima foi para os Estados Unidos, a convite de algumas universidades - sobretudo da Yve League -, a fim de realizar suas já notabilizadas conferências de divulgação do Brasil. Entendemos, entretanto, que a partir deste momento sua divulgação deixa de ter sentido enquanto política externa e passa a operar somente dentro da lógica das disputas intelectuais. Não é mais, assim, objeto de nosso estudo.

Cabe aqui, porém, pontuar um último episódio. Quase um último "respiro" de Oliveira Lima enquanto diplomata. O novo Chanceler a assumir o Itamaraty, Lauro Miller, apesar de mostrar tendência ao movimento de americanização da política externa brasileira e, diferente do Barão, não dar tanta importância para as relações com as Nações européia, nutria simpatias individuais para com Oliveira Lima. Além disso, via em Lima um dos mais valiosos quadros do Itamaraty, sobretudo por conta de seu perfil híbrido.

$\mathrm{Na}$ volta de sua jornada pelos Estados Unidos, no final de 1912, Oliveira Lima foi surpreendido por Lauro Miller com a rejeição de seu podendo de aposentadoria. Mais do que isso: Miller lhe oferecera o sonhado posto de Embaixador do Brasil em Londres. 
Sinto ter de alertar, mas o que se segue é trágico. Lima acatou com simpatia a decisão de Miller, mas parece que o Senador Pinheiro Machado não viu a situação com a mesma boa vontade. Tratou de travar a remoção de Oliveira Lima a Londres, justamente sob os argumentos de falta de lealdade de Lima para com o regime republicano. Rui Barbosa bem que tentou reverter a situação no Senado, sem sucesso.

Oliveira Lima não chegaria a assumir a Embaixada em Londres e tratou de reenviar seu pedido de aposentadoria, desta vez acatada. Com a aposentadoria definitiva de Oliveira Lima da carreira diplomática, acaba também o nosso estudo. 


\section{Conclusão}

O tema de nosso estudo foi a atividade de divulgação do Brasil no exterior empreendida pelo diplomata e historiador Manuel de Oliveira Lima. A atividade foi realizada de forma mais intensa entre os anos de 1908 e 1912, período correspondente àquele em que o diplomata ocupou o cargo de Ministro Plenipotenciário da Legação do Brasil em Bruxelas, Bélgica. Tratava-se de conferências em Academias e Universidades e de artigos para revistas literárias, nas quais Oliveira Lima versava sobre a formação histórica da nacionalidade brasileira e tecia críticas literárias sobre escritores brasileiros, a fim de que se divulgassem tais assuntos no exterior - mais precisamente em algumas capitais europeias.

Nossa primeira hipótese era a de que e que trava-se de divulgar para a Europa aquilo que era culturalmente produzido no Brasil em termos dos mesmos padrões civilizacionais, de modo posicionar o Brasil enquanto país civilizado nos trópicos, estando ele portanto no mesmo patamar das demais nações civilizadas europeias.

Nossa segunda hipótese era a de que a divulgação se relacionava de maneira complexa e articulada aos posicionamentos de Oliveira Lima diante das discussões intelectuais em torno da questão da nacionalidade brasileira e a uma política externa brasileira defendida e executada pelo diplomata diante das questões da inserção do Brasil no Mundo.

A fim de explorar estas duas hipóteses nosso trabalho foi estruturado em três capítulos.

O primeiro capítulo teve o objetivo de compreender Manuel de Oliveira Lima dentro de seu contexto intelectual. Neste sentido, exploramos algumas idéias fundamentais do ambiente naturalista, como "evolução" - dentro da perspectiva das teorias evolucionistas - e "Civilização". Nos atemos também às discussões em voga no ambiente intelectual brasileiro do final do século XIX e inicio do século XX, onde pudemos constatar a centralidade da questão da "construção da nacionalidade brasileira".

O segundo capitulo foi dedicado a explorar dos posicionamentos intelectuais de Oliveira Lima diante das questões e pautas presentes em sua rede de sociabilidade intelectual e nas instituições políticas e produtoras de conhecimento na qual circulava, a destacar o IGHB, a ABL e o Itamaraty.

Vimos que Oliveira Lima entendia a formação histórica da nacionalidade brasileira do ponto de vista das continuidades com as tradições portuguesas. Por esta via lusitana colocava 
o Brasil como pertencente às tradições latinas, e portanto, herdeiro das tradições européias no novo mundo. Compartilhava em certo grau, portanto, da idéia de que o Brasil se caracterizava como a "Civilização nos Trópicos". Esta compreensão se estendia à sua apreciação critica de autores e obras da literatura brasileira, para a qual compôs uma espécie de "Panteão Nacional" eleitos a partir de critérios de aproximação com as tradições europeias.

Enquanto diplomata, Oliveira Lima se apresentava como um dos principais pensadores das possibilidades de inserção do Brasil no Mundo, travando importantes e centrais diálogos com Joaquim Nabuco e Barão do Rio Branco. Lima se mostrava reticente com o entusiasmo de Nabuco com relação às aproximações com os Estados Unidos e via na manutenção e aprofundamento dos laços com as Nações europeias a estratégia adequada a ser adotada pelo Itamaraty. Rio Branco ia, a seu modo, conduzindo o processo de americanização da política externa brasileira sem deixar de valorizar a manutenção das relações com a Europa.

Vimos também a relevância que sua produção e reflexão historiográfica vinha ganhando, o que dava a Oliveira Lima cada vez mais prestígio e reconhecimento enquanto Homem de Letras. Vimos também como sua "incontinência na pena" e seu "quixotismo", sobretudo em polêmicas com Nabuco e Rio Branco, criavam empecilhos para suas condições nos corredores do Itamaraty.

O terceiro capítulo foi dedicado a explorar em maior detalhe a atividade de divulgação do Brasil no exterior, objeto de nosso estudo. Acompanhamos os contextos mais imediatos de suas conferências e artigos, assim como pontuamos as conexões de seus discursos com as concepções vistas nos capítulos anteriores.

Pudemos notar no estudo de sua atividade de divulgação como as questões de Oliveira Lima enquanto Homem de Letras e enquanto diplomata eram cada vez mais convergentes e articuladas. Juntamente com o prestígio que vinha ganhando na Europa diante do fama de suas conferências, Lima parece ter sido capaz de construir em torno de si a imagem de "Embaixador Intelectual do Brasil".

Notamos também a importância desta imagem nas articulações de seu desejo em ser removido enquanto Embaixador para um posto em alguma importante capital europeia - de preferência Londres - o que lhe garantiria acesso privilegiado a importantes acervos históricos - essenciais para sua produção historiográfica - e significativa posição na condução da política externa brasileira. 
Mesmo que ao final do processo Oliveira Lima não tenha conquistado o que almejava, nos parece que as hipóteses e conclusões a que chegamos neste estudo são válidas. Esperamos, enfim, ter contribuído para com os estudos sobre Oliveira Lima e sobre questões políticas e culturais da Primeira República brasileira. Esperamos também ter contribuído para com os estudos a partir de um ponto de vista interdisciplinar, sobretudo nas articulações entre a historiografia e a política externa brasileira. 


\section{Referências Bibliográficas}

\section{Obras de Manuel de Oliveira Lima:}

LIMA, Manuel de Oliveira. A conquista do Brazil. In: Revista do Instituto Histórico e Geográfico de São Paulo, Vol. XVII, 1912. 2a ed.

- A Festa da Sorbonne. In: SOBRINHO, Barbosa Lima (Org.).

Estudos Literários. Rio de Janeiro: Departamento de Imprensa Nacional, 1975.

- A Lingua Portugueza. In: O Estado de São Paulo, anno XXXV,

No 11024, 14 de fevereiro de 1909.

- A música no Brasil do ponto de vista histórico. In: SOBRINHO,

Barbosa Lima (Org.). Estudos Literários. Rio de Janeiro: Departamento de Imprensa Nacional, 1975.

. Cousas diplomáticas. Lisboa: A Editora, 1908.

. Dom João VI no Brasil. Rio de Janeiro: Topbooks, 1996. 3a ed. - Escritores Brasileiros Contemporâneos II: José Veríssimo. In:

SOBRINHO, Barbosa Lima (Org.). Estudos Literários. Rio de Janeiro: Departamento de Imprensa Nacional, 1975.

- Escritores Brasileiros Contemporâneos III: Olavo Bilac. In:

SOBRINHO, Barbosa Lima (Org.). Estudos Literários. Rio de Janeiro: Departamento de Imprensa Nacional, 1975.

- Escritores Brasileiros Contemporâneos IV: Rui Barbosa. In:

SOBRINHO, Barbosa Lima (Org.). Estudos Literários. Rio de Janeiro: Departamento de Imprensa Nacional, 1975.

. Escritores Brasileiros Contemporâneos VII: Joaquim Nabuco.

In: SOBRINHO, Barbosa Lima (Org.). Estudos Literários. Rio de Janeiro: Departamento de Imprensa Nacional, 1975.

- Formação Histórica da Nacionalidade Brasileira. 3a edição.

São Paulo: Publifolha, 2000. 
- Machado de Assis e sua obra literária. In: SOBRINHO, Barbosa Lima (Org.). Estudos Literários. Rio de Janeiro: Departamento de Imprensa Nacional, 1975.

- Nos Estados Unidos: impressões políticas e sociais. Brasília:

Conselho editorial do Senado Federal, 2009.

- No Japão: impressões da terra e da gente. Rio de Janeiro,

Laemmert, 1903.

- O Brazil e os extrangeiros. In: Revista do Instituto Histórico e

Geográfico de São Paulo, Vol. XVII, 1912. 2a ed.

- O Império brasileiro (1822-1889). São Paulo, Companhia

Melhoramentos, 1927.

- O movimento da Independência (1821-1822). São Paulo:

Edições Melhoramentos, 1972. 5a ed.

- Pan-americanismo: Monroe-Bolivar-Roosevelt. Rio de Janeiro:

H. Garnier, 1907.

- Sobre a evolução d'uma cidade do Novo Mundo do XVI ao XX

século, a propósito da recente transformação do Rio de Janeiro. In: O Estado de São Paulo, anno XXXIV, No 10893, 06 de outubro de 1908.

\section{Bibliografa Geral:}

ALONSO, Angela. Idéias em Movimento: A geração 1870 na crise do Brasil-Império. São Paulo: Paz e Terra, 2002.

ARRIGHI, Giovanni. $O$ longo século XX. Dinheiro, poder e as origens de nosso tempo. São Paulo: Editora Unes, 1994.

BETHELL, Leslie. Nabuco e o Brasil entre Europa, Estados Unidos e América Latina. In: Dossiê Joaquim Nabuco. In: Novos Estudos. São Paulo: CEBRAP, n. 88, dez. 2010.

BOSI, Alfredo. Literatura Brasileira, Volume V: O Pré-Modernismo. $3^{\text {a }}$ edição. São Paulo: Editora Cultrix, 1969.

BUENO, Clodoaldo. Política externa da Primeira República: os anos de apogeu (1902 a 1918). São Paulo: Paz e Terra, 2003. 
CARVAlHo, José Murilo de. Os Bestializados: O Rio de Janeiro e a República que não foi. $3^{\text {a }}$ edição. São Paulo: Companhia das Letras , 2009.

CHRLE, Chistophe. Ambassadeurs ou Chercheurs? Les relations internationales des professeurs de la Sorbonne sous la III République. In: Dossier, volume 14, janeiro de 1994.

CHEIBUB, Zairo Borges. Diplomacia e Construção Institucional: o Itamaraty em uma perspectiva histórica. In: Pensamiento Iberoamericano: Revista de Economia Politica. Madri: Instituto de Cooperación Iberoamericana, n.6, jul./dez. 1984.

DOPCKE, Wolfgang. Apogeu e colapso do sistema internacional europeu (1871-1918). In: SARAIVA, José Flávio Sombra (Org.). História das Relações Internacionais Contemporâneas: da sociedade internacional do século XIX à era da globalização. São Paulo: Ed. Saraiva, 2008.

DUROSELLE, Jean-Baptiste. Tout empire périra: théorie des relations internationales. Paris: Armand Colin, 1992.

FORSTER, Maria Thereza Diniz. Oliveira Lima e as Relações Exteriores do Brasil. Brasília: FUNAG, 2011.

FREYMOND, Jean, F. Rencontres de cultures et relations internationales. Relations Internationales, 1980, n. 24.

FREYRE, Gilberto. Oliveira Lima, Don Quixote Gordo. Recife: Universidade Federal de Pernambuco, 1968.

GARCIA, Eugênio Vargas. Diplomacia brasileira e politica exterior: documentos históricos (1493-2008). Rio de Janeiro: Contraponto, 2008.

GOLDSTEIN, Judith; KEOHANE, Robert. Ideas and Foreing Policy: Beliefs, Institutions, and Political Change. Ithaca: Cornell University Press, 1993.

GOMES, Angela de Castro. História e Historiadores. Rio de Janeiro: Editora FGV, 2013.

GOUVÊA, Fernando da Cruz. Oliveira Lima: uma Biografia. Recife: Instituto Arqueológico, Histórico e Geográfico de Pernambuco, 1973. 3 vols.

GUIMARÃES, Manuel Luis Salgado. Nação e Civilização nos Trópicos: o Instituto Histórico e Geográfico Brasileiro e o Projeto de uma História Nacional. In: Estudos Históricos. Rio de Janeiro, n 1. 1988.

HOBSBAWN, Eric J. A Era dos Impérios (1875-1914). 17 ed. Rio de Janeiro: Paz e Terra, 2014. 
HUDSON, Valerie. Foreing Policy Analysis: classic and contemporany theory. USA: Rowman \& Littlefield Publishers, 2007.

IUMATTI, Paulo Teixeira; VELlOzO, Julio César de Oliveira. Conhecimento, política e instituições no Brasil (1889-1934). Revue pluridisciplinaire du monde Lusophone, n², Université de Toulouse Le Mitral, 2013.

MALATIAN, Teresa. Oliveira Lima e a construção da nacionalidade. Bauru: EDUSC, 2001.

MARTIUS, Karl Friedrich Philipp von. Como se deve escrever a História do Brasil. In: Revista do IHGB. Rio de Janeiro, 6(24). Jan. 1845.

MERLE, Marcel. Forces et enjeux dans les relations internationales. Paris: Economica, 1985.

MICELI, Sergio. Poder, sexo e letras na República Velha: estudo clinica dos Anatolianos. In: Intelectuais à Brasileira. São Paulo: Companhia das Letras, 2008.

MILZA, Pierre. Politica interna e politica externa. In: RÉMOND, René. Por uma História Política. 2 edição. Rio de Janeiro: Editora FGV, 2003.

MOTA, Carlos Guilherme. Oliveira Lima e nossa formação. In: História e Contra-História: perfis e contrapontos. São Paulo: Editora Globo, 2010.

MORGHENTHAU, Hans Joachim. A política entre as nações: a luta pelo poder e pela paz. Brasília: Ed. Universidade de Brasília, 2003.

NEEDEL, Jeffrey D. Belle Époque tropical: Sociedade e Cultura de Elite no Rio de Janeiro na Virada do Século. $2^{\circ}$ edição. São Paulo: Companhia das Letras, 2003.

NYE Jr, Joseph. Soft Power: the means to success in world politics. Nova York: Public Affairs, 2004.

PRADO, Antonio Arnoni. Dois Letrados e o Brasil Nação: A obra crítica de Oliveira Lima e Sérgio Buarque de Holanda. São Paulo: Editora 34, 2015.

- Dois letrados e o Brasil nação: Sérgio Buarque de Holanda e Oliveira Lima (no prelo). Indefinido: Indefinido, 2010.

PUTMAN, Robert. Diplomacy and domestic politics: the logic of two-level games. Massachusetts: MIT Press. International Organization, v.42 n3, Summer 1988.

RENOUVIN, Pierre; DUROSELLE, Jean-Baptiste. Introdução à história das relações internacionais. São Paulo: DIFEL, 1967.

RICUPERO, Rubens. Rio Branco: o Brasil no mundo. Rio de Janeiro: Contraponto, 2000. 
SAID, Edward W. Cultura e Imperialismo. São Paulo: Companhia das Letras, 2011.

SALIBA, Elias Thomé. A Dimensão Cômica da Vida Privada na República Brasileira. In: SEVCENKO, Nicolau. História da Vida Privada no Brasil. República: da Belle Epoque à Era do Rádio. São Paulo: Companhia das Letras, 2010.

SARAIVA, José Flávio Sombra. História das Relações Internacionais: o objeto de estudo e a evolução do conhecimento. In: SARAIVA, José Flávio Sombra (Org.). História das Relações Internacionais Contemporâneas: da sociedade internacional do século XIX à era da globalização. São Paulo: Ed. Saraiva, 2008.

SEVCENKO, Nicolau. Literatura como missão: Tensões sociais e criação cultural na Primeira República. 2a edição. São Paulo: Companhia das Letras, 2003.

SIRINELLI, Jean-François. Os intelectuais. In: RÉMOND, René (Org.). Por uma história política. 2. ed. Rio de Janeiro: Editora FGV, 2003.

SOBRINHO, Barbosa Lima (Org.). Estudos Literários. Rio de Janeiro: Departamento de Imprensa Nacional, 1975.

(Org.). Oliveira Lima: Obra Seleta. Rio de Janeiro: Instituto

Nacional do Livro, 1971.

SKINNER, Quentin. Significação e compreensão na história das ideais. In: Visões da Política: sobre os métodos históricos. Algés, Portugal: Difel, 2005.

SUPPO, Hugo Rogélio; LESSA, Mônica Leite. $O$ estudo da dimensão cultural nas Relações Internacionais: contribuições teóricas e metodológicas. In: LESSA, Mônica Leite; GONÇALVES, Williams da Silva. História das Relações Internacionais: teoria e processos. Rio de Janeiro: Ed UERJ, 2007.

VELLOZO, Júlio Cesar de Oliveira. Um Dom Quixote gordo no deserto do esquecimento. Oliveira Lima e a construção de uma narrativa de nacionalidade. 2012.219 p. Dissertação (Mestrado em Culturas e Identidades Brasileiras) - Instituto de Estudos Brasileiros, Universidade de São Paulo, São Paulo.

WALLERSTEIN, Immanuel. O universalismo europeu: a retórica do poder. São Paulo: Boitempo Editorial, 2007.

WATSON, Adam. The evolution of the international society. A comparative historical analysis. London: Routledge, 1992. 
Sobre a evolução de uma cidade do Novo Mundo do XVI ao XX século, a propósito da recente transformação do Rio de Janeiro. Manuel de Oliveira Lima

\section{O Estado de São Paulo, 6 de outubro de 1908}

Repetia-se correntemente, há uns vinte annos, ao nosso mundo estudioso, um postulado que uma escola philosophica havia estabelecido com um dos seus princípios, de resto, ao que parece, muito discutido desde então e mesmo ulteriormente desmentido. Affirmava ella que a ontogenese, a saber, o desenvolvimento do indivíduo, offerecia um resumo da philogenese, a saber, do desenvolvimento da espécie, com a differença, evidentemente do tempo a menos. Poder-se-ia assim assistir num período curto a um processo da natureza que exige, para sua realização completa e ordinária, uma sucessão indefinida de séculos.

As cidades do Novo Mundo, consideradas sob este ponto de vista, offerecem um exemplo, notável no seu esforço, da longa evolução humano. Em três ou quatro séculos ellas passaram do estado da natureza ao estado da cultura, da animalidade completa a uma civilização refinada. Não falo dessas cidades americanas, muito típicas de resto, que nascem já crescidas e até ostentando de artifícios modernos. São estes casos de geração espontânea ou algumas vezes de maturidade precoce, que nem são exclusivos dos Estados Unidos. A nossa cidade de Bello Horizonte, no Brasil, a nova capital de Minas Gerais, nasceu em condições semelhantes. A cidade do Rio de Janeiro, capital do Brasil, forma pelo contrário um bello exemplo de uma cidade que passou por todas as phases, ilegível todas as formas, passou sucessivamente em três séculos e meio por todas as transformações que Roma atravessou em vinte séculos.

Apparição inesperada e encantadora, havia de aguardo para as primeiras navegações de simples exploração ao longo da costa ou em pesquisa da pastagem para o Oriente maravilhoso, o Rio de Janeiro deve, como cidade, sua origem à expedição da Bahia contra os francezes. Bahia era o centro da autoridade real portugueza no Brasil muito feudal de então; os francezes tinham prolongado suas discussões theologicas, acendendo-se ainda mais os 
rancores, esses rancores terríveis entre catholicos e calvinistas, no ilhote onde Villegagnon, cavalheiro de Malta, lançara os fundamentos da França Antarctica.

Os índios eram decididamente a favor dos francezes - uma sympatia que se repetia na América do Norte - e os portuguezes tiveram que empregar a violência e a astucia, a força e a diplomacia para vencerem sua resistência e poderem levantar seus primeiros abrigos de taipa, recobertos de ramagem. A moldura era soberba: montes de granito, densas florestas, praias doiradas, nada faltava e em proporções gigantescas, esmagando com sua grandeza este punhado de homens que queria avassalar essas regiões novamente ilegível e tinham que combater os elementos e os selvagens, a natureza e o homem, uma e outra egualmente bérbie $(?)$.

Não se julgando em harmonia, se guardara na Praia Vermelha, onde tinham desembarcado e acampado, e onde se realizam neste momento a Exposição Nacional comemorativa da abertura dos portos brasileiras commercio universal, os novos senhores avançaram na immensa bahia e escolheram, segundo a tradição mourisca e christan da Península Ibérica, uma eminência sobre a qual levantar seu primeiro forte e sua primeira ermida (?). Foi esse o chamado Morro do Castello, hoje ilegível arrazado para abrir caminho à formosa Avenida Central, que exigiu a demolição de mais de 600 casas, e que, cortando todo o bairro commercial, segue a beira mar num passeio único até a praia mesmo onde se effetuou a posse de uma região disputada por soberanos longínquos.

Os primeiros tempos foram difficeis. Os colonos agruparam-se por traz da palissada que circundava e defendia seu burgosinho europeu. Aos poucos, pelo auxilio dos Jesuítas, que foram nessa occasião os melhores agentes de civilização da America portugueza, começaram a aventurar-se fora. As terras das cercanias foram distribuídas em sesmarias, iniciaram-se as culturas de canna de assocar e de mandioca, entraram a ser exercidos todos os misteres pacíficos e belicosos, buscou-se ouro, escravizaram-se índios, pensou-se até nas coisas permanentes, erguendo-se conventos.

As casas desceram até a planície e o Rio de ruas cumpridas e estreitas, em forma de xadrez, onde o sol difficilmente penetra e por onde passaria a ilegivel em coche, esse Rio que apenas agora se transformou, começou a desenhar-se perto do porto, na qual as embarcações portuguezas se habituaram cada dia mais a vir ancorar. A existência não era muito alegre, nessa cidade em embrião; faltava toda e qualquer distração, excepção feita de algumas pobres 
festas da egreja. Os escravos, importados em número sempre crescente da Africa, faziam uma mancha negra, e mais se ouviam suas cantigas monótonas acompanhadas de dansas tristes (?) de que as queixas melancólicas e os cantos suggestivos dos portugueses, raça esta com a qual não tardaram aquelles a fundir-se.

Até o século XVIII o Rio quasi não conta. As lutas com os hollandeses, nascidas da passageira união de Portugal coma Hespanha que durou de 1580 a 1640, não perturbaram a sua existência humilde e tímida. Entretanto as lutas foram longas e tenazes (?): estenderam-se do Maranhão até a Bahia, e convulsionaram dois terços do Brasil, do então ainda Brasil de fachada, pois que o interior conservava ainda quasi toda a ilegível do mysterioso e do ilegível. O Rio não foi tomado de assalto ilegível a resgate senão mais tarde pelo famoso corsário bretão Duguay-Trouin, para vingara morte de seu camarada Duclere, que as ilegível da guerra de Sucessão tinham levado até a America do Sul. Justamente a cidade dava mostras de crescer graças as jazidas de ouro descobertas e exploradas em Minas Geraes desde o começo do século. A esta região deveria alias o Rio de Janeiro servir de saída e passagem econômica e commercial. Se o Rio se não expandia em florescências architetonicas, era porque fazia falta o gesto. Este recolhera-se em Portugal depois das exuberâncias do estylo mourisco (?), deste gothico ultra-trabalhado com reminiscências árabes, ilegível. $\mathrm{O}$ marquês de Pombal reconstruiu Lisboa, tornando-a regular mas ilegível depois do terrível terremoto de 1755 , e as construções sem elegância que datam desse período mostraram-se bem ilegível de todos os estylos que em França e noutros lugares engendraram por estes tempos verdadeiras obras primas.

Nada que relembre o ar majestoso de Luiz XIV, que denuncie as outras graciosas de Luis XV, ou que assinale a harmonia de linhas de Luiz XVII.

Pouco numerosos eram de resto os que podiam verificar além-mar tal ausência. Não se entrava facilmente no século XVIII na bahia do Rio, ou melhor, não desembarcava quem queira. Fazia-se mister uma razão seria, grandes ilegível a reparar ou uma missão autorizada a cumprir, para que esta embarcação alli fosse admitida e bem acolhida pela administração portugueza procurando, dizer-se-ia, não ser excedida pela hespanhola em matéria de fiscalização e de ilegível. Entretanto vários viajantes estrangeiros ahi fizeram curtas estadas de que nos deixaram suas impressões, e o porto depressa se tornou conhecido como o melhor dessas paragens para interromper uma navegação e renovarem-se os viveres. A agua 
sobretudo - uma agua de uma pureza e de uma excellencia proverbiaes - era um recurso e deveria ser um chamariz nessas intermináveis travessias, tanto para os navios que se dirigiam para o mar do Sul como para os que tinham a dobrar o cabo da Boa Esperança, a caminho das ilhas orientaes e da China.

Lord Anson - ou melhor, o capellão Walter que foi seu chronista por occasião da famosa viagem em redor do mundo - não poupou seus elogios ao Rio de Janeiro, gabando até a abundância dos estabelecimentos: o que outros negam, por exemplo o capellão do Conde de São Maio (?), não obstante seus gabos à cidade que ainda não era capital a uma lisonjeiras comparação estabelecida entre a colónia portugueza da Atlântico e as colônias hespanholas do Pacifico com relação à boa ordem no governo e no volume de trafico com a metrópole.

O abastecimento melhor ou peor dependia seguramente da occasião. Os recursos do Rio eram forçosamente modestos e as provisões não deviam ser em excesso quando havia ilegível, como no momento da passagem do Conde, em 1740 - não faltando o lugar - 70 navios mercantes portuguezes, os quaes alguns de grande tonelagem. Tratava-se do chamado comboio do Brasil, que vinha cada anno de Portugal trazer suas mercadorias e levar nossos produtos, navegando de ilegível e sob a proteção de dois ou três navios de guerra.

Os últimos vice-reis do Brasil trataram de aformosear a cidade do Rio de Janeiro de accordo com seu gosto, ou melhor, com bem raras excepções de accordo com seu máu gosto. O exemplo partia de cima e estavam na moda as construções monumentaes e os jardins decorados de obras de arte. Devem-se-lhes, entre outras coisas, o aqueducto de arcos romanos que apparece na maior parte das vistas desde então desenhadas da capital brasileira, e o passeo publico de sombrio arvoredo escondendo repuxos de conchas e figuras de bronze. John Barrow, a caminho da Cochinchina, com a embaixada inglesa teve ensejo de escrever nos primeiros annos do século XIX, que os portuguezes do Rio, se pouco tinham feito para embellezar a natureza, pelo menos ao lhes devia attribuir o mérito negativo de não terem feito muito para afeial-a. A tonallidade da cidade era por ventura mais sacra que profana, posto que o amor nella desempenhasse um papel dos mais importantes. A Hespanha, mesmo ecclesiastica, não era todavia tanto quanto a exppuzeram certos viajantes de passagem antes da abertura dos portos o que, tendo durante todo o dia um ilegivel na sua pista, eram forçados, quando chegava o anoitecer e tocavam as Ave-Marias, a volver para bordo sendo-lhes estritamente vedado pernoitar em terra. 
As casas todas eram protegidas, como acontecia em tempos antigos com os deuses (?) lares, por imagens da Virgem ou dos Santos, frequentemente collocadas na parte de fóra, debaixo de vidro, em nichos diante dos quaes ardia o ilegível clássico das devoções. Procissões povoariam a cada instante as ruas num grande estrepito de musica militar e grande fartura de irmandades e de crianças vestidas de anjinhos com saiotes entufados e azas de gaze, enquamto os foguetes estalavam no ar e os ilegível faziam ouvir seus alegres carrilhões ou seu triste dobre.

A corte portugueza tendo-se estabelecido no Rio de Janeiro ha justamente um século, havendo-se a família real transladada inteira por motivo da invasão de Portugal pelos soldados de Napoleão, a cidade aumentou consideravelmente o lucro debaixo de todos os pontos de vista .Seu perímetro alargou-se muito, estendendo-se os bairros em differentes direções; os negócios tomaram um novo desenvolvimento; os estrangeiros entraram a fornecer uma nova e importante parcella da população; o theatro juntou-se à egreja para distrair o publico e os espectaculos da realeza alliaram-se com as ceremonias religiosas, rivalizando com estas em esplendor.

O grupo, que se denominou a colonia dos artistas franceses, tendo à sua frente o Le Breton, ex-secretario perpetuo (nada mais era perpetua depois da Revolução francesa) da Academia de Bellas Artes de Paris, a qual el-rei d. João VI mandou buscar e que abrangia entre outros pintores Debret e Taunay, o esculptor Taunay, irmão do prescedente, o architecto Grandjean de Montigny, o gravador Pradier, educou o gosto nacional e o revestiu, relevandome (?) a expressão, do verniz europeu que lhe faltava. E vemos no Rio edifícios de estylo greco-romano posto em voga pelo império: arco do triumpho em tela pintada levantados para festas dynasticas; bailados alegóricos na Opera, replutos de recordações mytologicas exactamente ilegível nas margens do Sena. Os cortejos e mascaradas, de que houve com abundância, foram dispostos por aquelles persistentes e mais agradaram a população do Rio, que desde então deu prova de sua grande jovialidade, de que as ilegível introduzidas pelos fidalgos portuguezes, dos quaes eram o principal desporto, e do que as corridas de cavallos, importadas pelos negociantes ingleses estabelecidos à sombra de regimes de favor que lhes fôra outorgado pelo reconhecimento do mais fiel dos alliados.

Após ter sido durante treze annos a casa da realeza portuguesa, foi o Foi de Janeiro durante 67 annos a sede do império brasileiro. Dois ilegível e, a separara-los, um regência 
democrática de nove annos, ahi viveram. Assistiu-se a imptisados ilegível e a consortes principesas e a funeraes imperiaes; assistiu-se ao desfilar victorioso das tropas que voltavam o Paraguay, e ao desfilar menos triumphal das que voltavam da Cisplatina, assistiu-se a revoluções pacificas, como a de 1831, que determinou a abdicação de d. Pedro I, e a de 1889 que fez exilar d. Pedro II e a mudanças, verdadeiras subversões na economia da pais, como a abolição da escravatura em 1888, livremente votada por um Parlamento, sobre a acção de um gabinete reformador ilegível chamado ao poder pela princesa regente.

No systema politico a capita exerceu as mesmas funções que o coração no apparelho circulatório, por este orgão passando todo o sangue e delle dependendo toda a vida. Quer isto dizer que a vida no Rio não podia faltar nem movimento nem interesse. Por vezes the faltaria alegria. A partir do anno de 1810, um verdadeiro flagelo tinha-se ilegível introduzido enfim - a febre amarella, importada de Nova Orleans, revelando-se logo de começo por violentas epidemias, tornando-se um seguida endêmica e lançando sobre todo o paiz uma sombra de tristeza, ao mesmo tempo que emprestava uma das poucas reputações a um clima até ahi julgado excellente.

Avalia-se em perto de 80.000 o numero das victimas da terrível mal, somente no Rio de Janeiro. A primeira epidemia custou a vida a mais de 4.000 pessoas. Todo o progresso do Rio ressentiu-se naturalmente disso. Era como se uma crise repentina e grave invadisse um organismo em pleno vigor e ameaçasse sustar-lhe a florescência. As grandes obras que acabam de ser executadas ou que ainda estão de via de execução no Rio, realçando por tal forma um secnario natural da maior belleza, teriam sido, pelo menos em parte paralisadas se a presença dela cruel inimiga de todos os instantes não houvesse paralysado a nossa energia.

Estudou-se e discutiu-se muito a febre amarella, mas só nestes últimos annos se chegou a entendel-a effetivamente, e o Brasil não descurou interessar-se pelas novas theorias scientificas e applicadas. A sciencia medica, em grande honra no Brasil, não pode aduzir um testemunho mais valioso do seu mérito do que a extincção quasi absoluta dessa tremenda enfermidade, e nenhum titulo mais justo pode allegar a estima publica: o anno passado o numero total dos casos foi de 48, numa população de perto de 800.000 almas. Em Santos, que era peor refugio, ha annos que a febre amarella desapparecera. Assim se produziu a rehabilitação de todo um paiz pela certeza de ter sua capital, ilegível como cada dia se mostra mais com todas as graças da arte, não escoando agora sob suas ilegível um veneno mortal. A 
cidade do Rio de Janeiro é reconhecida no grande homem do trabalho que se chama dr. Oswaldo Cruz por havel-a saneado e orgulha-se da sua feliz transformação.

Como vos disse, mais de 600 casas, pela maior parte da época colonial, foram demolidas só no bairro commercial, para abrir lugar a uma das mais bellas avenidas do mundo, bordada de edifícios sumptuosos e indo de mar a mar, enquanto a outra avenida acompanha numa enorme extensão as sinuosidades das praias, deixando-se admirar de um lado a bahia magnifica e do outro o esplendido secuario de montanhas e de florestas.

Vienna, 9 de setembro de 1908.

Oliveira Lima 


\section{A lingua portugueza \\ Manuel de Oliveira Lima \\ O Estado de São Paulo, 14 de fevereiro de 1909, página 1}

Portugal, possuindo uma tão bella história, não podia deixar de ter uma literatura notável, dada a estreita dependência que existe entre os factos históricos e as manifestação do gênio literário, relação não menos intima nem menos necessária do que aquella que liga naturalmente a expressão do pensamento. Onde germinam ideias, floreia o discurso, o saber, as letras, que são sua forma concreta, que as espalham e ao mesmo tempo se encarregam de registrar e conservar para o ensino da posteridade as seções que se tornam dignas disso pelo seu brilho ou que servem para tal fim pelo seu negrume. A história é, todos bem sabem, a mestra da vida na expressão latina.

A língua é a condição primeira de sua literatura. Pode existir uma língua particular ou mesmo particularista, sem que exista uma língua nacional, mas o caso é raro e o phenomeno mais raramente ainda completo. Vós sois uma das exceções: quase sempre o produto carece de vigor e de personalidade. De outro lado, é evidente que uma língua se constitui verdadeiramente por meio de uma sucessão de esforços literários. Uma língua sem literatura, se fosse possível entre as gentes civilizadas, seria uma condemnada a dasapparecer num curto prazo. Para seu desenvolvimento ella precisa também de uma athmosphera de liberdade e de independência. As nações vencidas e extintas afirmam sua vitalidade pela língua, e ao que se fundem com os conquistadores e perderem sua individualidade ou mesmo começam renunciando à sua língua.

O português por exemplo, de que me vou occupar esta noite, é uma derivado, exuberante como o hespanhol moderno ou antigo castelhano, o galiciano ou melhor o gallego e o provençal, de uma mistura em que entram, em primeiro lugar e como origem bem distante, e que domina, menos genericamente o celtico ou, em espécie, o lusitano, em summa, o dialecto falado pelas tribos celtibericas da costa occidental da península hispanica, semelhantes ou diferentes de outros dessa origem comum, cujos documentos nos faltam quasi por completo; o latim em dose muito forte, de modo a tornar-se o fundamento principal della; o alano, o suevo, o visigodo ou outros dialectos germanos ou bárbaros, por accasião das 
invasões sucessivas que destruiram o império romano; finalmente o árabe, por efeito da subjugação que durou do século VIII ao XII. Se o português se desenvolveu paralelamente com o castelhano e se ao atrophiarem os outros galhos da mesma arvore, quando de começo havia tão pouca diferença entre todos os ramos que o português e o gallego quasi se confundiam, é porque Portugal se organizou como nação independente no século XII e que a uma nação independente convinha seguramente uma língua autônoma. O português curva-se perante o castelhano quando o senho constante da união ibérica se desenha como uma realidade e, pelo contrario, ergue-se e invoca altivamente seus títulos e pergaminhos quando o paíz trata de prover à sua continuidade histórica.

Depois que o latim, um latim inteiramente em decadência, quasi macarrônico, deixou de ser a língua legal e cedeu o passo ao português nos documentos públicos, o hespanhol tornou-se durante um tempo, digamos por séculos, a língua fina e aristocrática, como o era o francês na Prússia, no século XVIII e na Russia mesmo depois disso. Os poetas de corte, não os dos cancioneiros da corte de do rei Dom Dinis, elle próprio trovador, que tinham adaptado os modelos provençais à sua língua informe e hesitante, mas os da corte ja sumptuante de Dom João II e de Dom Manuel, cultivavam o hespanhal de preferencia à língua nacional, escolhendo-o para seus desportos literários, de um sabor meio-sentimental, meio cavalheiresco, com um travo ja de melancolia. Uma elaboração profunda tinha-se entretanto produzido ao mesmo tempo no seio dessa nova formação philologica, que correspondia a uma nova nacionalidade, e não somente o povo não cedia - e quando tal acontece, são os outros que tem que ceder - como prosadores, Fernan Lopes para somente citar o maior dos poetas bucólicos, Dernardim Ribeiro, para somente citar o mais conhecido, fizeram della o instrumento das suas chronicas e das suas englogas e novellas pastoraes.

Entre os séculos XIII e XIV foi o português considerado official na sua própria terra: durante o século XV adquiriu sob a penna dos sus primeiros escriptores e feitio característico que lhe ficou, e no século VVI recebia dos grammaticos a disciplina que verteria torna-lo clássico.

Um pouco mais tarde, nos fins do século XVI, quando Portugal já tendo atravessado o período mais glorioso de sua historia e cumprido a melhor parte de seu destino, depois de ter descoberto as Indias, a Terra Nova, o Japão e o Brasil, e assim revelado ao mundo antigo o mundo novo e o mundo mais antigo, perdeu por algum tempo sua independência e tornou-se 
hum reino a mais na immensa monarchia dos Philippes, uma tradição vigorosa, uma personalidade literária se achava constituída para servir de base à resistência.

Os eruditos podem mesmo ensaiar uma reação dita purista, aproximando ainda mais o português do latim para afasta-lo do hespanhol. Esquecia-se em demasia que outros elementos tinham entrado na combinação, mas o facto é que os dois idiomas, o português e o hespanhol, tinham perdido para todo sempre seu typo local e primitivo e adquirido seu caráter definitivo debaixo da poderosa acção romana. Roma foi a influencia civilizadora, foi ella que organizou administrativamente, religiosamente, militarmente, judiciariamente esta região hispanica inculta no moral tanto quanto no physico.

Não é pois de surprehender que a sua língua se transformasse no que justamente se appelidou línguas neolatinas, distinctas desde o momento que a historia de cada uma das duas nações da península tomou uma direcção differente.

O latim todavia que conheceis, nunca foi, mister é ter presente, a língua presente corrente das províncias hispânicas, como de resto o foi tampouco em Roma entre o povo refiro-me, bem entendido, ao latim literário, a língua de Cicero e de Tacito. Falava-se além de Ebro, na Betica como na Lusitania uma língua rústica ou vulgar, ao lado da língua por assim dizer official ou nobre, em uso na solennidade do culto, nas arengas das legiões, e nos discursos nos tribunaes, empregada portanto a implorar os deuses nos templos, a levantar o ardor militar, a pedir justiça ou isempção de impostos. O idioma dos conquistadores havia entretanto distinguido tão fortemente num certo ponto sobre a linguagem popular que Strabão, o famoso geographo, escrevia a respeito de algumas das tribus celtibericas, que ellas tinham inteiramente adoptado os costumes romanos e que a mor parte dos que as compunham, esquecendo a língua tradicional, as tinham feito latinas.

$\mathrm{Na}$ realidade a civilização iberica foi sobretudo, foi fundamentalmente latina. Antes dos romanos não existia cultura hispanica: temos provas abundantes disso. Os vestígios romanos encontram-se donde a organização municipal, que enobreceu e lhe emprestou tradição de governo, até as superstições correntes que são formas de expansão imaginativa e da alma popular. A língua entretanto escapou a uma tão completa assimilação e foi até infiel à sua mestra que se tornara uma segunda mãe. Sob um certo ponto de vista pode mesmo dizerse que o elemento nacional chegou a tomar sua desforra de uma longa ponte que fecunda submissão às influencias estrangeiras, quando o português as substitui completamente como 
língua de governo e de justiça ao latim, o qual por seu lado se convertera na língua eclesiástica, o que bastava para assegurar-lhe a perpetuidade.

Aconteceu porém que, por um encadeamento que não é raro neste dominio, a língua primitiva dissolvera-se em virtude de fusão com a língua importada, e que a língua resultante da união das precedentes offerecia todo o aspecto, senão phonetico, etymologico, morphologico e syntactico do latim. Creio memso, e não sou o único desta opinião, que idioma algum, dos derivados desta língua, traz uma maior semelhança com ella. Não é portanto erro dizer-se que o português deriva do latim: é de todo ponto exacto dizer que deriva sobretudo delle. Para ser mais preciso, dever-se-à ajuntar que uma fonte principal foi a língua popular de Roma - termos quotidianos ou "língua militaris" - modificada ou melhor purificada sob a acção dos eruditos e dos puristas. Deparam-se-nos desde os primeiros séculos da era christan pairando acima dos rudes dialectos ibéricos, autores latinos e dos melhores, nascidos em Hespanha - Seneca e Marcial entre outros, o moralista e o epegrammetista de fama perpetua. Trata-se porém ahi de productos de uma cultura estrangeira ainda que acclimada, soberbos frutos de estufa em summa, com relação ao seu meio. A produção literária espontânea, natural, rica de seiva e com o sabor da terra, apparece bem mais tarde, em embryão nas canções e romances populares a que o Romantismo de hontem emprestaria a forma perfeita, para chegar, por uma evolução regular, a florescer no século XVI, nas estrophes de Camoens e nas paginas de João de Barros, ao calor do sol que ardia verdadeiramente do Oriente.

Uma poesia aristocrática imitada dos trovadores que passeavam de côrte em côrte, no Occidente, seu brio cavalheiresco e seu ardor christão, de a estes sentimentos novos a vestimenta de uma nova língua; mas o amor não brotava menos, e fóra de toda convenção, dos lábios populares, ao mesmo tempo que o enthusiamo se acendia ao contacto das narrativa dos jograes que, repetindo seus cantos, fragmentos esparsos de uma epopéia franca, vagabundeavam pelos países onde Roma estava fazendo a conquista moral dos bárbaros que tinham destruído seu poderio. Foi assim, por meio desta dupla corrente oriunda do estrangeiro, que a língua nacional, a começo hesitante, se affirmou, se envigorou, se amplificou, adquiriu plasticidade, perdeu de sua dureza e de sua grosseria, e ganhou graças às suas novas maneiras uma flexibilidade e uma elegância de bom tom. 
O mesmo aconteceu com a língua portuguesa que com os sentimentos que lhe coube exprimir: sua formação traz as differentes influencias a que andou sujeita. O caso é idêntico do hespanhol. Godos e Arabes trabalharam sobre o fundo neo-romano, trazendo os primeiros a contribuição de sua altiva rude e de sua energica vontade, os segundo, a da sua polidez figurada, da sua competência artística e do seu conhecimento das sciencias exactas. Glottologicamente, o hespanhol denuncía por certo mais que o português a influencia árabe nos seus sons gutturaes, o português por ventura mais que o hespanhol a lembrança dos Alanos nos sons ilegível fortes. A tarefa dos humanistas, que não deixaram mesmo durante a Meia Idade, de manter a tradição dos estudos clássicos, mas que tomaram com a Renascença um novo e glorioso vôo, foi de podar, de purificar, de cinzelar a linguagem popular e fazer della a linguagem nobre que nós conhecemos, perdendo em pitoresco o que ganhava em dignidade até que, no século XIX, o Romantismo lhe reconstituísse o pitoresco sem lhe roubar a dignidade. A língua é mais do que qualquer outra manifestação o espelho da alma de um país e opulenta-se de dotes à medida que as qualidades colletivas se desprendam e exhibam. Pelo que toca ao português, o contacto com o Oriente, trazido pelas descobertas, juntou aos seus característicos a maneira pomposa; a vehemencia da receção religiosa e a lisonja do regimen absoluto emprestaram-lhe emphase; as tradições de independência e de grandeza deram-lhe eloquencia; as novas aspirações de liberdade e de progresso ilegível, delinearam a sensibilidade. Junto todas e por uma progressão continua e secular, tantos predicados formam dessa língua uma das mais ricas, das mais prendadas, das mais próprias às variações infinitas, com a condição naturalmente de se saber fazer reler o instrumento. $\mathrm{O}$ artista de temperamento sempre as avantajará ao simples amador, mesmo apaixonado de arte.

A poesia popular portuguesa era, como as outras, acompanhada no começo de dansa e de musica. Na sua grande variedade de formas, de que algumas se tornaram tradiciohes e subsistem até nossos dias, podem-se facilmente descobrir, perfeitamente distinctas, as qualidades essenciaes das differentes raças que a engendraram. Descobre-se ahi o amor do maravilhoso dos Celtas, como a gravidade religiosa dos Germanos, ou a voluptuosidade árabe. Naturalmente foi a poesia popular a mais influenciada pelo lyrismo oriental, tendo as populações christan e musulmana vivido durante séculos na maior harmonia; quando à poesia de côrte, esta approximou-se o mais possível dos modelos latinos que os estudos clássicos faziam sobressair. 
Os cancioneiros, de um dos quaes a Sra. Michaelis de Vasconcellos acaba de publicar uma sabia edição; e os romanceiros que Garret, o pontífice português do romantismo, foi o primeiro a renovar literariamente, documentam-nos largamente sobre taes correntes e suas fontes. Prosa ou verso, cantos lyricos ou contos heróicos, não foi a fantasia nacional única em ilegível. A grande criadora foi mais uma vez cosmopolita: as tradições locais uniram-se às contribuições estrangeiras. Assim os Cruzados do Norte, alguns delles das vistas terras, qua a caminho do Mediterraneo ajudaram a conquista de Lisboa em poder dos Mouros e fixaram-se em numero assas considerável no novo reino, e também os peregrinos que com destino a Roma ou à Terra Santa faziam aguarda nessa extremidade da Europa antes de passar as Colunas de Hércules, ajudaram seguramente tanto quanto os troveiros e os jograes errantes a transplantação das poesias do cyolo carlovingio, as chamadas canções de gesta e as canções de amor. O rei Affonso III, que antes de subir ao throno, residira e até casara no sul de França, foi egualmente um agente instinctivo de propagação de semelhante gesto literário. A approximação entre o espirito português e o espirito francês tornou-se por completo evidente, caracterizado e consciente sob o rei Diniz, nos fins do século XIII e começos do século XIV, precisamente quando a língua portugueza se organizava como língua autônoma e se revelava como língua literária, à sombra do lyrismo provençal. Ella conservou esta posição adquirida máu grado os poetas cortezãos, cujos espíritos, e em alguns os corações, se inclinavam para Castella. Penso ter-vos dito que o chamado rei lavrador da historia portugueza, ao mesmo tempo que com sua imitação algo antiquada prolongava a poesia dos trovadores, prescrevia o emprego da língua vulgar nos documentos officiaes até entanto redigidos em latim da peor decendencia.

A independência política de Portugal affirmou-se de modo inequivocado em Aljubarrota, com a derrota dos hespanhois em fins do século XIV. Uma rainha inglesa partilhou o throno do vencedor, o mestre de Avis que se tornou El-Rei Dom João I, e brindou o país com uma geração de homens de guerra, de homens de sciencia e de homens de Estado, pois todos seus filhos foram personalidades notáveis. Não é de surprehender que então se fixasse observar a influencia britannica nas tradições cavalheirescas do género dos poemas da Távula Redonda; mas mercê da proximidade geographica da communidade de origem, não podia a influencia castelhana deixar de ser bem mais forte e mais durável. Exerceu-se esta mesmo sobre a imaginação popular por meio dos romances; de que uma parte possuía o sabor 
mourisco, ou mais rigorosamente granadino, e o castelhano que ja então era o hespanhol, ficou sem contestação a língua fina, a língua dos serões do Paço com suas justas poéticas e suas representações theatrais. Gil Vicente, que entretanto era do povo, serviu-se do hespanhol em preferencia ao português para os seus autos tão engenhosos e mordazes, que prenunciavam com uma bella aurora o theatro nacional.

O periodo em que viveu e trabalhou este moralista - reinado de Dom Manuel - marca com effeito o apogeu da influencia castelhana, pois foi o tempo em que quasi se consumou, graças aos matrimônios reaes, a velha aspiração, aspiração sempre viva de resto na alma hespanhola, da união ibérica. Gil Vicente criticava os costumes de sua época; sua veia cômica inesgotável exercia-se às custas dos vícios e ridículos da sociedade que o cercava, suas sátiras repousavam sobre um grande numero de tradições, de superstições, de mytos, de legendas, que era bem os elementos moraes de um povo, conquanto apresentados a uma côrte cujas tendências intellectuais eram estrangeiras.

Antonio Ferreira praticou um acto verdadeiramente de coragem quando, ao escrever sua famosa tragédia "Ignes de Castro" - a infeliz amorosa cujas desventuras fizeram a ventura de tantos dramaturgos, provocando as lagrimas do publico - escolheu um assumpto nacional e o compor em linguagem exclusivamente nacional. Deu mesmo a esta forma de nobreza, fazendo-a servir à tragédia, a mais altaneira das espécies literárias.Passava-se isto em pleno século XVI: neste século ainda o capricho pelo hespanhol cedeu muito à influencia italiana, eclipsando-se diante da onipotência de Dante, de Petrarche e de Boccagio. Foi a influencia que Sá de Miranda adaptou e pos na moda, e que distingue a Renascença em Portugal.

Evidentemente trata-se de producção literária. Pelo que toca à poesia popular, a perda da independência durante 60 anos por motivo da anexação em tempo de Philippe II, combinada com certa predisposição espiritual proveniente do elemento judeu, numeroso e activo antes que o tribunal da inquisição realizasse sua obra de depuração pelo fogo, explica um aspecto prophetico e religioso da sua florescência. $\mathrm{O}$ feitio mental tornou-se messiânico e ficou alguma coisa disso através dos séculos seguintes.

Sobre a literatura propriamente dita, a influencia que immediatamente a hespanhola, culpável então de todos os gongorismos. Seguiu-se-lhe por sua vez a franceza, consorciada com o renascimento romântico e que se conservou toda poderosa. 
Todas essas diversas influencias estrangeiras, aliás communs a todas literaturas européas sem excepção, penetradas umas por outras, oppuseram-se à formação de uma grande epopéa nacional emanada do povo. A epopéa de Camoens, de renome universal, traduzida em todas as línguas, não foi mais que uma epopéa erudita; não foi uma producção colletiva, espontanea; ainda que graças ao gênio de um homen tivesse absorvido e traduzido maravilhosamente o sentimento patriótico commum, no momento mesmo em que se ia verificar a perda da nacionalidade.

A circunstância de ser um poema erudito não o impediu aliás de ser num sentido original. A poesia épica franceza tinha deixado poucos vestígios em Portugal, conquanto a origem da nação remonte à doação do feudo de Portucale ao príncipe Henrique de Borgonha nos começos do século XII. A cultura clássica impunha-se desde o inicio e derivava muito naturalmente sua inspiração das fontes latinas.

Latina era egualmente a liturgia romana, e era-o exclusivamente, pois que as intromissões populares tinham sido banidas pela disciplina ecclesiástica à medida que a instituição monástica crescia com a attribuição das terras conquistadas sobre os infiéis.

A poesia provençal era única em possuir no país livre saída, não se contentou com desenvolver o gosto: chegou a modificar o portuguez. Pouco a pouco affastou-se este do gallego, com o qual se confundia quasi de principio, operando pelo contrario sua fusão com o dialecto do sul do Algarve, ultima região tomada aos mouros e onde sua marca fora mais forte porque durante mais tempo seu domínio. A evolução da língua portugueza, uma vez separada de sua irmã gêmea, acompanhou a evolução política do país, quer dizer o desenvolvimento da côrte dos reis da dynastia de Borgonha, e mais pronunciada se realizou no memento em que foi mais considerável a influencia dos trovadores.

Os artificios métricos da poesia provençal não poderiam servir à inspiração popular, e vemos com effeito que tanto a versificação quanto a língua dos cantos populares não são semelhais às que se usavam na côrte. No entanto, o cultivo provençal, e grande mérito lhe assiste por isto, poliu o portuguez suavizando sua prosódia e aperfeiçoando sua syntaxe, introduzindo mesmo locuções novas. Acontece sempre assim. A língua vulgar é distincta da língua literária, mas uma não pode bem viver independente da outra, quer diser que a língua popular dever, para fixar-se e prosperar-se, submeter-se ao tratamento grammatical e sofrer a disciplina literária; ao passo que a língua literária, para se não immobilizar, e para não ficar 
fóra de moda e obsoleta, deve sempre desalterar-se nas camadas inferiores e, consformandose com os caprichos da inventiva popular, renovar suas formas e suas expressões.

As línguas mortas, diria o Sr. de La Paliese, são as que não se falam mais correntemente, ou melhor, as que não se transformam mais, que se tornarão immutaveis. A vida é, como o sabeis, uma continua metamorphose. Notaste por acaso que as múmias, posto que conservadas intactas sob suas faixas, de modo que podeis ser postos em presença de um Pharaó de ha 30 séculos, cujos traços poderá detalhar, não produzem em vós sensação alguma pungente, ao passo que não poderia olhas sem emoção para o cadáver de um desconhecido que seja, atirado à valla commum e que se vae dissolver, quer dizer, transformar-se?

O grande segredo da sugestão exercida pela epopéa portugueza das Lusíadas, de que a pouco vos falava e que todos vós conheceis do nome senão de leitura, reside em que ella faz appello de recordações clássicas, mas também sobretudo às tradições nacionaes. O povo comprehendeu-la logo e della derivou um orgulho muito justo da sua nacionalidade. Durante os 60 annos que durou a união com a Hespanha, o poema de Camoens foi reimpresso 36 vezes. Estas edições sucessivas e tão approximadas denotam bem a que ponto Portugal ahi encontrava a melhor versão e a melhor esperança de sua independência. Uma nação enfim varonil, que havia escutado coisas tão belas e tão grandes, não podia certamente resignar-se a morrer escrava de outra. A liberdade lhe voltaria num súbito arranco de cólera e de brio. E se Camoens foi o arauto das glorias nos dias de alegria, foi egualmente o confidente dos pesares nos dias de afflição. Entretanto os números poemas épicos que tinham imitado os Lusíadas e dos quaes alguns contribuíram a dotar de mais riqueza e brilho a língua em progressão, caiam no olvido que é a sorte das producções literárias que se não recommendavam por um interesse verdadeiramente humano, e que são apense pejadas de reminiscências mytologicas e de fabulas engenhosas.

A literatura portugueza promette aos que a estudaram agradar ilegível. É uma literatura tão abundante e variada quanto a língua é opulenta e harmoniosa. Não se derivará menos prazer em travar conhecimento com esta, que se ha exercido em todos os géneros literários, desde as novellas de cavalaria como o Amadia (?) de Gaule e o Palsyerim (?) de Inglaterra, que deram a volta à Europa e serviram de modelo à essas obras de ficção animadas do sopro heroico da Edade Média e descidas à caricatura genial do Dom Quixote, até os sermões repletos de imagens e de suptileza do mais eloquente dos pregadores e missionários jesuítas, o 
padre Antonio Vieira; donde as obras ditado dos reis, mas que são na verdade a história de um povo e de uma nação onde apparece e se affirma o espirito público, até os panegyricos emphaticos das numerosas academias officiais e privadas, os quais não passam do exaggero dos annos das conquistas; desde os sonetos em que o amor espiritualizado dos trovadores se materializa ao contacto do humanismo da Renascença, para chegar às composições arcadicas, de um acabado perfeito mas de um sabor insípido, até o renascimento do lyrismo do século XIX, quanto o sentimento sincero da natureza se combina com a paixão carnal e com a vibração intellectual.

Para dar-vos uma idéa da doCura e da harmonia da língua portugueza, permitti que vos leia em portuguez um soneto, universalmente conhecido de resto, do grande Camoens:

"Alma minha gentil que te partiste..."

$\mathrm{Na}$ opinião unanime dos que possuem algum conhecimento da língua portugueza, este soneto encerra uma graça especial, uma suavidade e um encanto incomparáveis de que a traducção não vos pode dar mais que um vago e debil reflexo, por mais talento que nella despenda o artista.

A traducção seguinte do referido soneto a Natercia, a qual acompanha muito de perto o texto portuguez, é devida a uma poeta, Maru Legraud, que acaba de fallecer:

"Ame miene e charmant, ..."

Permitti também que destaque dos Lusíadas o episódio da Ignes de Castro, na tradução do fino letrado que é o Sr. conde de Azevedo, antigo ministro de Portugal na Bélgica:

'Livrée à un paisible repos, tu profitais, belle Ines, ..."

O portuguez é alem de tudo, força é notal-o, uma língua universal. Acantonada na Europa na extremidade occidental do continente, diante da qual se abre o mar immenso, uovila-eis falada nas ilhas que salpicam nesse oceano, o oceano das descobertas inspiradas por Henrique o Navegador; por mais 20 milhões de pessoas no Brasil, nação que occupa quasi a metade de um continente e cujo porvir já deixou de ser uma promessa, pois que se tornou uma realidade admirável; na Asia, isto é, nas Indias, na China, por toda parte onde o espírito de aventura e de lucro levou os conquistadores no século XVI e onde, sós por algum tempo, se estabeleceram vencedores; na Oceania, onde seus descendentes partilham com a Hollanda a soberania de uma ilha; na Africa principalmente, nas suas duas costas, a oriental e a occidental, onde o império portuguez confina com aquelle que deveis a feliz e esclarecida 
iniciativa de nosso rei e ao esforço intelligente e tenaz de vossos compatriotas, que quiseram, após alguns séculos de intervallo, reatar as tradições ousadas dos vossos marinheiros. Todas as línguas da Europa não podem blazonar de uma disseminação semelhante. O japonez que hoje se fala accusa numa serie depararas a lembrança viva das relações desse paiz com os portugueses nos séculos XVI e XVII, e na costa de Malacca do mesmo modo que em Ceylão a infiltração philologica denuncia egualmente antigo e frequente trato.

Inscrevendo o portuguez no programma da Escola das Sciencias Commerciaes, Consulares e Coloniaes da Universidade de Lovain, praticastes um acto de justiça e tomastes uma sabia medida que certamente vos aproveitará: resta apenas agora assegurar o desenvolvimento e a applicação que tal idea comporta e merece. Também tereis assim honrado, o que não é para desprezar, vossas próprias tradições, pois que mestres portuguezes disseram no século XVI ouvir suas vozes do alto das cathedras desta Universidade, ao mesmo tempo que o professor Cleynarte (?), hellenista, hebraisante e arabista, que fazia parte do vosso corpo docente, visitava a Universidade de Coimbra e lhe concedia o titulo lisonja de "Nova Athenas".

Lovain, 18 de janeiro de 1909.

Oliveira Lima 